\title{
Behavioral Aspects of Household Portfolio Choice: Effects of Loss Aversion on Life Insurance Uptake and Savings
}

\author{
In Do Hwang*
}

The views expressed herein are those of the authors and do not necessarily reflect the official views of the Bank of Korea. When reporting or citing this paper, the authors' names should always be explicitly stated.

\footnotetext{
* Economist, Economic Research Institute, The Bank of Korea, Tel: +82-2-759-5362, Email: hid@bok.or.kr.

I thank my advisor, Jeffrey R. Brown, dissertation committee co-chair Nolan H. Miller, committee members, David Molitor and Scott J. Weisbenner, and Professor Dan Bernhardt, Dr. Joonyoung Hur, Hyun Chang Yi, and an external reviewer of BOK Working Paper for valuable comments and suggestions. A part of empirical results included in this paper was previously distributed under the title, "Framing-proof Complete Insurance Markets under (Narrow) Framing and Loss Aversion." This paper uses the HRS public data and the RAND HRS public data. I thank numerous contributors of the data sets. This paper benefited from discussions with participants at the University of Illinois at Urbana-Champaign Summer Seminar (2015), the Missouri Valley Economic Association 52nd Annual Meeting (Kansas City, 2015), the Midwest Finance Association Annual Meeting (Atlanta, 2016), and the Bank of Korea Seminar (Seoul, 2016). I gratefully acknowledge the financial support by University of Illinois Graduate College Fellowship, Summer 2015 and Summer 2016.
} 


\section{Contents}

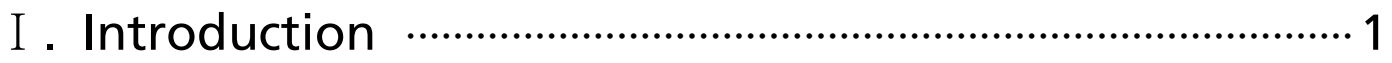

II. Background: Life Insurance and Related Literature $\cdots .5$

III. Model: Loss Aversion, Term-Life Insurance, and Saving …11

IV. Empirical Tests Using the Health and Retirement Study $\quad \cdots .24$

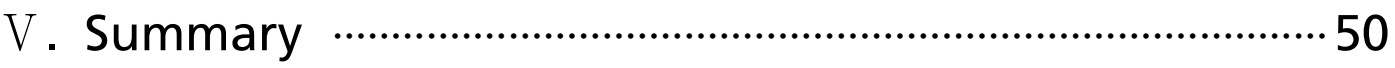

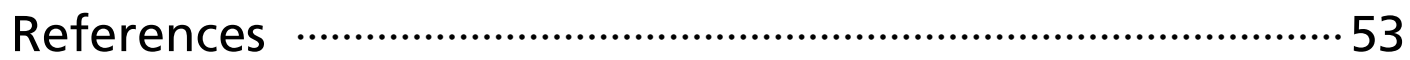

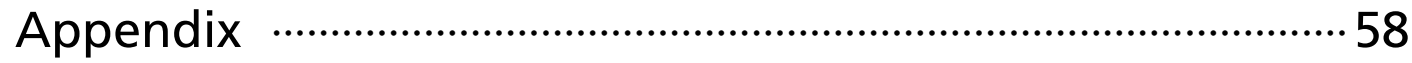




\section{Behavioral Aspects of Household Portfolio Choice: Effects of Loss Aversion on Life Insurance Uptake and Savings}

This paper investigates how loss-aversion affects individuals' decisions on savings and insurance purchase. Specifically, this paper empirically tests if prospect theory's loss aversion decreases insurance demand and increases savings demand. Prospect theory predicts that boundedly rational consumers may view pure protection insurance, such as term-life insurance, as a risky investment because the insured may lose premiums if a bad event does not occur within the pre-specified term. Hence, those who are fairly sensitive to the potential loss choose not to buy term-life insurance. Instead, they may choose a more safe option to prepare for uncertain future events by increasing precautionary saving. This paper tests such prediction using individual-level data from the Health and Retirement Study (HRS) and finds empirical evidence consistent with the prediction: loss-averse individuals are less likely to own term-life insurance and more likely to own whole-life insurance, which serves as a partial savings instrument. These individuals also hold a higher level of wealth than others, suggesting that they tend to save more (presumably for precautionary motives), all other things being equal.

Keywords: Loss aversion, Term life insurance, Whole life insurance, Precautionary saving, Prospect theory

JEL Classification: D03, D14, G22 


\section{I . Introduction}

An increasing number of studies demonstrate that behavioral factors such as loss aversion and narrow framing affect consumers' insurance purchase decisions. A recent study by Gottlieb and Mitchell (2015) shows that the elderly who are subject to narrow framing, i.e., those who view each problem within a narrow frame and hence fail to recognize the risk hedging effect of insurance, are less likely to hold long-term care insurance (LTCI). Hwang (2016a) also notes that boundedly rational consumers may evaluate insurance within a narrow frame of "gain vs. loss." In an empirical analysis using a representative sample of low-to-moderate income U.S. citizens, Hwang finds that loss averse individuals have a low ownership rate of LTCI, supplemental disability insurance (SDI), and private health insurance. Hwang's findings may be described as a "penny wise and pound foolish" behavior: loss averse individuals are sensitive to potential losses in premiums but they tend to neglect possible large losses in wealth, which can be caused by accidents or health problems. As a result, loss aversion decreases insurance demand.

However, the two studies have not considered the possibility that loss aversion may distort savings decisions as well. The literature on precautionary savings suggests that savings can be a partial substitute for insurance: Individuals can prepare for uncertain future events by either purchasing insurance plans or by accumulating more wealth, which can serve as a financial buffer. Hence, loss-averse individuals may choose savings as a means to prepare for uncertain future events rather than choosing pure protection insurance, which may cause losses. In other words, loss aversion may decrease the demand for insurance and increase the demand for precautionary saving.

This paper tests empirically if loss-aversion depresses insurance demand and stimulates precautionary saving. This paper measures individuals' loss-aversion using a series of risky investment questions in the Prospect Theory Module of the Health and Retirement Study (HRS) 2012 (i.e., accept or turn down risky investment opportunities that have equal chances of receiving $\$ 115$ or paying $\$ 100 ; \ldots$; receiving $\$ 300$ or paying $\$ 100$ ). The loss-aversion measure is then 
merged with the life insurance ownership data and the wealth data in the HRS 2012. In particular, this paper focuses on three types of assets that differ from each other in the insurance vs. savings element: (1) term-life insurance (pure insurance), (2) whole-life insurance (partial insurance + partial savings), and (3) net worth (savings). If loss-aversion stimulates savings and depresses insurance demand, then loss-averse individuals should be more likely to hold whole-life insurance rather than term-life insurance, and they should hold a large amount of net worth as a result of savings.

The empirical test results, which analyze about 1,100 individuals aged 60 or older, are found to be consistent with the above hypothesis. First, the U.S. elderly with a high degree of loss aversion show a significantly low ownership ratio of term-life insurance and this result is robust to various control variables (age, gender, income, wealth, education, family size, employment status, bequest motives, and the constant relative risk aversion measure), alternative estimation methods, and parametric forms of variables. For example, this paper reports that among those with high loss aversion (those who turn down the receiving-\$300-or-paying-\$100 investment) only 34.2 percent own term life insurance, while of those with low loss aversion 41.5 percent own term life insurance. In terms of the total coverage amount of term-life insurance as well, the two groups show a significant difference. Secondly, the U.S. elderly with a high degree of loss aversion show a high ownership ratio of whole-life insurance, which accumulates the cash value and hence serves as a partial savings vehicle. This result is more significant when we limit the samples to those who own any type of life insurance. Specifically, for those who own any type of life insurance (either term-life or whole-life), one unit increase in loss aversion is estimated to raise the probability of owning whole-life insurance by 6.60 percent point. Thirdly, this paper shows that a household with a loss-averse household head or spouse tends to hold a higher level of net worth. The empirical results on households' net worth have remained robust when we restrict the samples to age cohorts, exclude extreme values, or apply different specifications, although the significance of this evidence is slightly weaker than the results found in term-life and whole-life insurance choices. Finally, in terms 
of the composition of net worth, loss-averse individuals are found to be less likely to hold stocks but more likely to hold non-risky assets such as deposits in checking/savings/money market accounts, CD, and bonds.

This paper contributes to the existing literature on loss aversion and household portfolio choices by presenting the first micro-level evidence of how loss aversion relates to precautionary saving. The most closely related study is that of Hwang (2016a), which presents individual-level evidence that loss aversion depresses consumers' willingness to purchase insurance. Hwang's study, however, does not explore the possibility that loss aversion may distort saving decisions as well. Another related study is about loss-aversion and households' stock market participation (e.g., Benartzi and Thaler, 1995; Dimmock and Kouwenberg, 2010). This paper confirms evidence that loss aversion discourages stock market participation using a representative sample of the U.S. elderly; it extends the result by showing that not only stocks but also insurance demand falls off due to loss aversion based on the same individuals data set. Thereby, this paper provides firm evidence that insurance can be perceived as a "risky investment" like stocks for those who lack financial knowledge, as presumed by Kunreuther, Pauly, and McMorrow (2013) and Cole et al. (2013).

This paper is also related to the literature on the behavioral economics of retirement saving (for reviews, see Benartzi and Thaler, 2007), which demonstrates the importance of default options and the prevalence of heuristics in savings decisions. The paper contributes to the literature by introducing loss aversion as another behavioral factor affecting savings decisions. Its novel feature lies in the identification strategy. To examine how loss aversion affects savings decision, this paper examines two types of life insurance that differ in the savings element: term-life, which has no savings element, and whole-life, which has a substantial savings element, and then figures out if the finding in term-life vs. whole-life choices can be generalized to conventional savings through the investigation of households' net worth. By showing that loss aversion leads to under-insurance and over-saving, this paper sheds light on the puzzle of why the elderly tend to dissave little after retirement, a 
phenomenon that is called the savings puzzle (Kotlikoff, 1988) or the annuity puzzle (Benartzi, Previtero, and Thaler, 2011). While there are excellent studies that directly link loss aversion and savings behavior, they explore the relationship in a completely different context: in the studies by Aizenman (1996), Bowman, Minehart, and Rabin (1999), Kőszegi and Rabin (2009), and Pagel (2016), loss aversion increases savings because people are assumed to be loss-averse with respect to consumption (i.e., the degree of pain from a drop in consumption from the reference level is greater than that of pleasure from an increase), but not with respect to insurance premiums as this paper assumes. Hence the domain of loss aversion in the previous literature is entirely different from this paper. ${ }^{1)}$ Lastly, this paper adds to the literature on life insurance take-up (Bernheim, 1991; Zietz, 2003; Outreville, 2014; Mountain, 2015) by identifying another determinant of life insurance uptake, loss aversion.

This paper is organized as follows: Section 2 reviews the related literature. Section 3 provides background information on prospect theory and constructs a permanent income/life cycle savings-insurance model when individuals are subject to behavioral biases, especially narrow framing and loss aversion. It derives five testable implications from the model: (1) Loss aversion decreases the demand for term-life insurance. (2) Loss aversion may increase the demand for savings (precautionary saving). (3) Since whole-life insurance is a combination of insurance and savings, loss-aversion may have either a positive or a negative impact on the holdings of whole-life insurance. (4) Two weights for bequests (bequest weight for the death at $t+1$ vs. bequest weight for the death at $t+2$ ) have different impacts on term-life insurance and savings. Specifically, an increase in the bequest weight for $t+1$ (premature death) increases the demand for term-life insurance but decreases the demand for savings. In contrast, an increase in the bequest weight for $t+2$ (expected death) decreases the demand for term-life insurance but increases the demand for savings. (5) The effect of loss aversion on the demand for term-life insurance is

1) Since the loss aversion measure of this paper captures the attitude to losses in investments when the amount of loss is small, the measure is more likely to capture an attitude to losses in insurance premiums than losses in consumption. 
amplified by the degree of narrow framing and the expected survival probability. Section 4 empirically tests the five testable implications of the model using individual-level data from the HRS. It first examines if ownership of term-life and whole-life insurance is associated with loss-aversion, and then focuses on if households' total wealth level is also associated with loss-aversion. Section 5 summarizes the results.

\section{Background: Life Insurance and Related Literature}

\subsection{Institutional background of life insurance}

\section{Term-life vs. whole-life insurance}

Life insurance is a type of insurance that pays out lump-sum death benefits to a designated recipient upon the death of an insured person. Depending on the duration of the protection, life insurance can be classified into two types: term-life insurance, which covers a specified term (e.g., 10, 15, 20, or 30 year terms), and whole-life insurance, which covers a policyholder's entire life. Specifically, the face value of term-life insurance is paid out to beneficiaries only if the insured die within a specified term. In contrast, the face value of whole-life insurance is paid out upon the insured death regardless of the timing of the death. Another important feature of whole-life insurance is that it also serves as a savings vehicle because part of the premiums is used to accumulate the cash value. Hence, whole-life insurance can be regarded as a combination of insurance and savings, while term-life insurance provides a pure financial protection (Brown, 2001). Indeed, policy-holders of whole-life insurance can borrow money based on the cash value of the insurance policy. LIMRA (2014) reports that there were $\$ 131$ billion in whole-life insurance loans outstanding in the U.S. in 2013.

Whole-life policies owned by the elderly include substantial savings elements. Specifically, Brown (2001) reports that, based on the 1995 Survey of Consumer Finance, the median cash value held by the U.S. individuals aged 70 
Figure 1: Proportion of Protection and Savings Elements in a Whole Life Insurance Contract Issued at Age 35

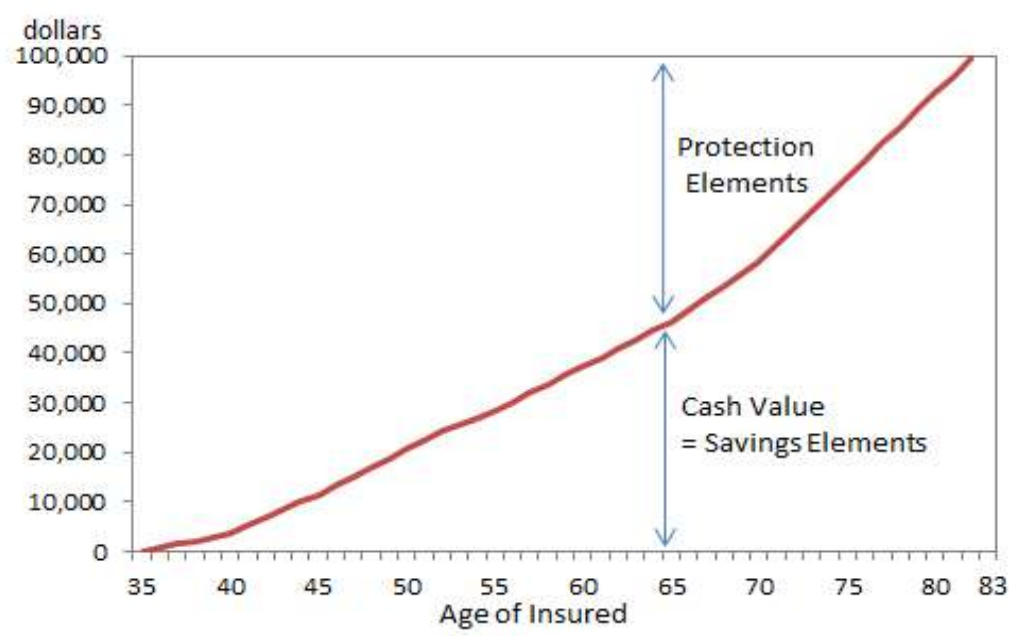

Notes: Based on a 35-year-old nonsmoking male with a preferred-rate of a $\$ 100,000$ whole life insurance policy sold by New York Life Insurance Company. Life expectancy of the person is assumed to be 83 .

Data Source: Insure.com (2015), Data retrieved from http://unww.insure.com/life-insurance/cash-value.html

or older is 67 percent of the face value. The high proportion of the savings element is not surprising because the savings elements of whole-life insurance increase with a policy-holder's age, while the pure insurance elements decrease. Figure 1 illustrates the cash value of a whole-life policy with a face value of $\$ 100,000$ sold by New York Life Insurance Company. One can see that cash value or savings elements increase substantially with age.

Although term-life insurance provides protection only for a pre-specified term, most term-life insurance policies sold in the U.S. are renewable up to a maximum age limit. This means that policy holders can sign up for another term period at the end of the initial term, without having to show that the insured are in good health (Department of Financial Service of New York State; Brown 2001). Premiums due on renewal, however, tend to increase substantially. The maximum age limits vary across insurance companies. For example, the maximum age limit is 95 in the case of MetLife, which has the largest market share in the U.S. life insurance market. 


\section{Individual vs. group policy}

Group life insurance is a type of life insurance that covers an entire group of people. Group life insurance is typically offered by an employer or professional association to its employees or members. The most common type of group life insurance is employer-provided term-life insurance. Employers pay some or all of the premiums of term-life insurance as a part of a benefits package. Many employers limit the coverage of group term-life insurance to $\$ 50,000$ because employees are subject to income tax if the coverage of employer-provided term-life insurance exceeds $\$ 50,000$ (IRS, 2016).2)

Unlike group life insurance, individual life insurance is purchased, maintained, and controlled by an individual. Even if the insured change a job, the coverage of individual policy is not affected by the change unlike the employer-provided policy. Thus, what is closely related to an individual's willingness to ensure themselves is individual life insurance rather than group policies.

\subsection{Literature}

\subsubsection{Determinants of life insurance take-up}

Studies by Mossin (1968), Yaari (1965), and Fisher (1973) lay the theoretical foundation for the determinants of life insurance. These studies point out that risk aversion, bequest motives, labor income, wealth, and prices (premiums of insurance, returns of other assets) are determinants of life insurance demand. Specifically, those who have high risk aversion and strong bequest motives are more likely to buy life insurance, and those who live by working are more likely to purchase insurance than those who live off the proceeds of their wealth (Fisher, 1973).

Despite the theoretical importance of risk aversion in insurance demand, little empirical evidence is reported on the relation between the measures for risk-aversion and ownership of life or non-life insurance. Green (1963, 1964)

2) Retrieved from https://www.irs.gov/government-entities/federal-state-local-governments/group-term-life-insurance. 
explores the relationship between the two. He measures individuals' risk aversion using attitudes toward small and large gambles. He concludes that there is no correlation between risk aversion and ownership of health, auto, and life insurance. Similarly, recent studies by Gottlieb and Mitchell (2015) and Hwang (2016a) find no association between the CRRA measure for risk aversion and ownership of long-term care insurance, supplemental disability insurance, or private health insurance. Another line of research attempts to measure the magnitude of each household's risk, so-called 'financial vulnerability' (e.g., volatility of standard of living in case a major income earner of a household is to die), and investigates its association with insurance ownership. Bernheim, Carman, Gokhale and Kotlikoff (2003), Bernheim, Forni, Gokhale and Kotlikoff (2003), and Mountain (2015) find no association between a household's financial vulnerability and its life insurance ownership. In contrast, Lin and Grace (2007) report that households' financial vulnerability is positively associated with life insurance ownership.

Rather than using direct measures for risk-aversion, most empirical studies on insurance purchasing behavior have used demographic variables (e.g., age, gender, family structure) as a proxy for risk aversion due to a difficulty of measuring attitudes toward risk. These studies have reported inconsistent and contradictory results as to which effects (positive vs. negative effects) such demographic factors have on the take-up of life insurance (Zietz, 2003; Outreville, 2014). Specifically, Outreville's (2014) literature survey reports that "Almost all past research dealing with panel or survey data in the United States has focused on life insurance purchasing behavior as a function of various demographic and socioeconomic variables" (p. 170). For example, the literature has included gender, age, marital status, and education as the proxies for risk aversion based on the fact that women, elderly, married, and undereducated individuals are more risk-averse. Regarding the effect of demographic variables on life insurance, prior studies have reported mixed results. For example, Outreville's literature survey summarizes the effects of age on life insurance holdings as follows: half of the literature reports a positive association of age with life insurance holdings while the other half reports a negative association. 
Some studies report an insignificant relation between age and life insurance holdings. Similar contradictory findings are reported on the effects of education, marital status, and family size on life insurance ownership. ${ }^{3)}$

Several studies associate bequest motives with life insurance take-up. Bernheim (1991) suggests empirical evidence indicative of strong bequest motives using income and insurance ownership data on the U.S. elderly. Bernheim finds that a high level of social security benefits is positively associated with ownership of life insurance, and concludes that this could be evidence of a strong bequest motive. The rationale for this conclusion is that individuals buy life insurance to de-annuitize their wealth because, under strong bequest motives, individuals can be over-annuitized by government-provided Social Security annuities. Bernheim's annuity offset model of life insurance is carefully examined by Brown (2001) using detailed life insurance ownership data in which two types of life insurance (term-life vs. whole-life) are distinguishable. Brown shows empirical evidence to the contrary of the annuity offset model, including the facts that (i) many individuals own term-life insurance and private annuities at the same time, and (ii) Social Security benefits are not significantly positively associated with holdings of term-life insurance.

\subsubsection{Behavioral factors and insurance buying decisions}

A growing body of research has begun to explore the effects of behavioral tendencies on insurance purchasing decisions. However, to my knowledge, no empirical evidence is provided for the life insurance market. An earlier study by Johnson et al. (1993) shows that availability heuristics and framing effects are associated with individuals' willingness to pay for insurance (flight, auto, and

3) These inconsistencies in empirical studies seem to be associated with the possibility that demographics variables affect insurance holdings through multiple channels. For example, gender affects insurance holdings directly or indirectly through its association with risk aversion. Specifically, being female means that the person is less likely to be a major income earner of a household; hence, females are less likely to demand life insurance (direct impact). But in terms of risk aversion, females are more risk averse than males; hence, women may have a higher willingness to pay for insurance (indirect impact through risk-aversion). 
disability insurance). For example, the study shows that consumers express a higher willingness to pay for insurance when the relevant accident comes across their mind readily and vividly (availability heuristics). It also shows that consumers tend to prefer expensive return-of-premium insurance to much cheaper insurance that returns a lower amount of money, which is actuarially better (framing effect: guarantee or rebate frames are preferred). An experimental study by Brown, Kling, Mullainathan, and Wrobel (2008) also reports a similar framing effect: people's willingness to pay for annuities is affected by the way annuity products are described, i.e., the insurance-on-consumption frame vs. the investment frame. Only recently have researchers begun to relate behavioral factors to real-world insurance holdings data beyond the laboratory settings. (for reviews, refer to Camerer (2004) and Barberis (2013)). Gottlieb and Mitchell (2015) show that narrow framing, as measured by an indicator variable for whether a respondent changes his decision when problems are presented within a negative frame, is negatively associated with ownership of long-term care insurance using the HRS data set. Bhargava, Loewenstein, and Sydnor (2015) analyze health insurance choices of workers at large firms and find that their choices are subject to heuristics. Hwang (2016a) focuses on the role of loss aversion and shows that loss aversion, as measured by the amount of acceptable losses in small-amount gambles, is negatively associated with the holdings of long-term care insurance, supplemental disability insurance, and private health insurance using the American Life Panel data. Hwang points out that the majority of prior studies have neglected to consider the role of loss aversion in insurance take-up because most prospect-theory-based studies have assumed that individuals assess insurance products entirely within the "loss domain", not within both the gain and loss domain as Hwang assumes (pp. 3-4, 38-30). 


\section{Model: Loss Aversion, Term-life Insurance, and Saving}

\subsection{Background: prospect theory's loss aversion \& insurance}

Loss aversion means people's tendency to be more sensitive to losses than the same amount of gains. This is one of the most important features of Kahneman and Tversky's $(1979,1992)$ prospect theory. Prospect theory states that people decide whether to buy a prospect or a lottery based on the expected value of potential gains and losses from the reference point. More formally, prospect theory states that the gain-loss value from a prospect is $\sum w\left(p_{i}\right) \nu\left(x_{i}\right)$, where $w(\cdot)$ is the probability weighting function, $p_{i}$ is the probability of possible outcomes, $\nu(\cdot)$ is the value function, and $x_{i}$ is a random variable representing losses or gains from the prospect. Kahneman and Tversky specify the value function as $\nu(x)=\left\{\begin{array}{ll}x^{\alpha} & \text { if } x \geq 0 \\ -\lambda(-x)^{\tilde{\alpha}} & \text { if } x<0\end{array}\right.$, where $\lambda$ is the coefficient of loss aversion. Figure 3 (b) illustrates the value function. According to prospect theory, whether to participate in a lottery depends on several parameters, such as the degree of loss aversion $(\lambda)$, reference point (this determines gains or losses, $\left.x_{i}\right)$, probability weighting $(w(\cdot))$, and the degree of diminishing sensitivity $(\alpha, \tilde{\alpha})$. Kahneman and Tversky (1992) have found that, in their laboratory experiments, most people exhibit a $\lambda$ greater than one. Kahneman and Tversky estimate $\alpha=\tilde{\alpha}=0.88$.

This paper focuses on the role of loss aversion when a particular reference point is adopted. It also examines how loss aversion interacts with the expected survival probability. This paper, however, does not focus on the role of diminishing sensitivity because this paper assumes that insurance is evaluated in both the gain and loss domains as in Hwang (2016a), where $\alpha$ and $\tilde{\alpha}$ play little role.

If people assess the value of insurance as they access the gain-loss value of a lottery, then the value of insurance is negatively associated with the degree of loss aversion, $\lambda$. Hence, loss-averse individuals may be less likely to purchase insurance. Specifically, the expected gain-loss value of a prospect, $\mathrm{E}[\nu(x)]$, is negatively associated with the degree of loss aversion $\lambda$. To see this, suppose the 
probability of gain from a prospect is $p$ and the probability of loss from the prospect is $1-p$. Furthermore, assume $w(p)=p$ for simpliticy. In this case, the expected value of the prospect is $E v=p^{*} \operatorname{Gain}^{\alpha}-(1-p)^{*} \lambda^{*} \operatorname{Loss}^{\tilde{\alpha}}$. Hence, the value from a prospect is negatively associated with the degree of loss aversion. The two underlying assumptions in deriving the result are as follows: first, people have narrow framing (i.e., people isolate risk) in the sense that they only care about the gain-loss value of a prospect, not about the diversification effect that the prospect will bring to their existing portfolio; second, the reference point is "the wealth level when one does not engaging in the prospect," which means that no gains or no loss occurs if a person does not take action for buying insurance (See Proposition 1 of Hwang (2016a)). One can also see that loss aversion interacts with ' $1-p$ ' (i.e. $\left.\partial E v / \partial \lambda=(1-p)^{*} \operatorname{Los} s^{\tilde{\alpha}}\right)$. This implies that the effect of loss aversion is large among those who believe that an accident will not occur.

To exemplify the effect of loss aversion, consider a lottery that has 50-50 chances of winning $\$ 200$ or losing $\$ 100$. Further assume that a person has a preference with $\alpha=\tilde{\alpha}=1, w\left(p_{i}\right)=p_{i}$. One can show that whether this person will accept or turn down the lottery depends on the person's degree of loss aversion $(\lambda)$. For example, if the person has a $\lambda$ of three, the person will turn down the lottery because the gain-loss value of the lottery is negative $\left(0.5^{*} \$ 200^{1}-0.5 * 3.0^{*} \$ 100^{1}=-\$ 50\right)$. If the person has a $\lambda$ of 1.5 , then the person will accept the lottery because the gain-loss value becomes positive. $\left(0.5^{*} \$ 200^{1}-0.5^{*} 1.5^{*} \$ 100^{1}=+\$ 25\right)$.

\subsection{Model}

This paper considers the effect of loss aversion on life insurance take-up and savings within the context of Dynan, Skinner and Zeldes' (2002; 2004) life cycle/permanent income model with a bequest motive. In this model, individuals face uncertainties regarding future earnings and the length of life. There are three periods in the model $(t, t+1$, and $t+2)$. Figure 2 illustrates the 3-period model of uncertain lifetimes. 
Figure 2: Three Period Model of Uncertain Lifetimes

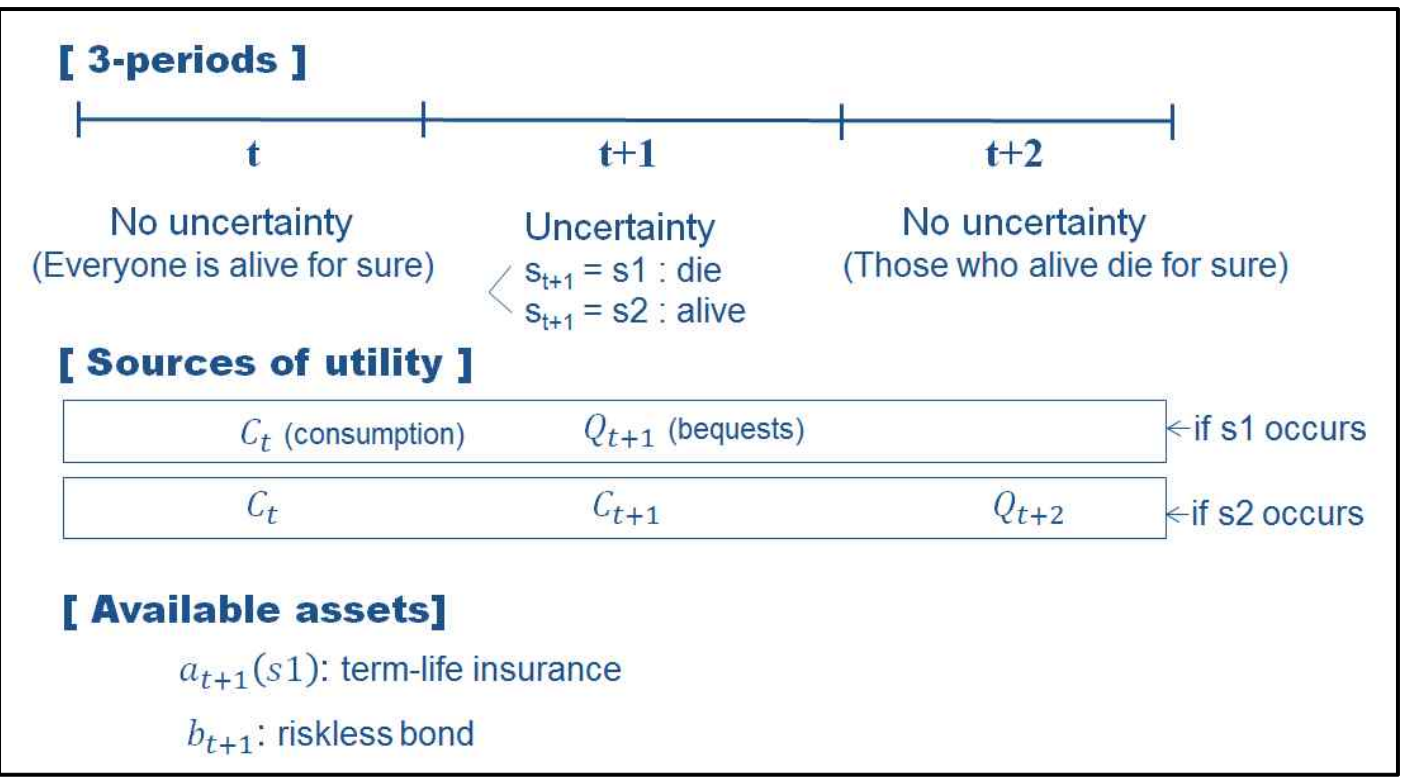

Source: Author's illustration

Individuals are alive for sure at $t$, but it is uncertain whether they will survive at $t+1$. Those who survive at $t+1$ die for sure at $t+2$. One can think of period $t$ ("young") as ages 30-60, period $t+1$ ("old") as ages 60-90, and period $t+2$ as the time around death, as Dynan et al. point out (2004, p. 403). The two possible states of the second period are notated as $s_{t+1}=\{s 1, s 2\}$. If $s 1$ is realized, then the person dies at the beginning of $t+1$. If $s 2$ is realized, then the person survives at $t+1$ (and dies at $t+2$ ). The amount of bequests he/she leaves in the event of death at the beginning of $t+1$ and $t+2$ is $Q_{t+1}$ and $\mathrm{Q}_{t+2}$ respectively. Individuals' subjective probability of experiencing $s 1$ and $s 2$ is $\pi_{1}$ and $\pi_{2}$ respectively, where $\pi_{1}+\pi_{2}=1$. Faced by uncertain lifetimes, in the first period $(t)$, an individual decides how much to consume, save, and buy term-life insurance. If the individual is alive in the second period $(t+1)$, the person decides how much to consume for himself/herself and set aside for inheritance.

Most previous studies, including Dynan et al. (2002; 2004), assume a perfectly rational consumer and use the following preference specification: a 
consumer maximizes expected lifetime utility coming from consumptions $\left(\mathrm{C}_{t}\right.$, $\left.\mathrm{C}_{t+1}\right)$ and bequests $\left(\mathrm{Q}_{t+1}, \mathrm{Q}_{t+2}\right)$ :

(2.1) $\widetilde{E U}_{t}=U\left(C_{t}\right)+E_{t}\left[D \cdot \beta \cdot G_{t}\left(Q_{t+1}\right)+(1-D) \cdot \beta\left\{U\left(C_{t+1}\right)+G_{t+1}\left(Q_{t+2}\right)\right\}\right]$

$\mathrm{D}$ is an indicator variable that is equal to one if $s 1$ (death) is realized and zero otherwise. $\mathrm{U}(\cdot)$ and $\mathrm{G}(\cdot)$ represent utility functions for consumptions and bequests. $\beta$ is a discount factor $(0 \leq \beta \leq 1)$.

This paper extends the domain of preference: it assumes a boundedly rational consumer who gets utility not only from consumptions and bequests but also from the "gain-loss" utility of risky assets, following the prospect theory literature (e.g., Barberis, Huang, and Santos, 2001; Hwang, 2016a). A boundedly rational consumer maximizes the following expected utility:

(2.2) $E U_{t}=U\left(C_{t}\right)+E_{t}\left[\hat{b} * v(a)+D \cdot \beta \cdot G_{t}\left(Q_{t+1}\right)+(1-D) \cdot \beta\left\{U\left(C_{t+1}\right)+G_{t+1}\left(Q_{t+2}\right)\right\}\right]$

(2.3) $v(x)= \begin{cases}x^{\alpha} & \text { if } x \geq 0 \\ -\lambda(-x)^{\alpha} & \text { if } x<0\end{cases}$

(2.4) $U\left(C_{t}\right)=\frac{c_{t}^{1-\gamma}}{1-\gamma}$

(2.5) $G_{t}\left(Q_{t+1}\right)=\hat{d_{t}} \frac{Q_{t+1}^{1-\gamma}}{1-\gamma}, \gamma>0, \hat{d_{t}} \in[01]$

The term $\nu(a)$ represents the gain-loss value of insurance, where $\nu(\cdot)$ is Kahneman and Tversky's (1979) value function and $a$ is the quantity of term-life insurance.4) One important parameter of the value function is $\lambda$, a coefficient of loss aversion (See 2.3). The utility function for consumptions and bequests is assumed to be the CRRA utility function, which has a risk aversion parameter $\gamma$ (See equations (2.4-2.5)). As a result, the insurance-savings model in this paper incorporates both the risk aversion measure $(\gamma)$ and the loss aversion measure $(\lambda)$.

Table 1 and Figure 3 compare the risk aversion measure with the loss aversion measure. While loss aversion decreases insurance demand, risk aversion increases insurance demand. If the negative effect of loss aversion on insurance demand is dominated by the positive effect of risk aversion, then a

4) The term $v(a)$ can be re-written by $D * \operatorname{Gain}^{\alpha}-(1-D) * \lambda * \operatorname{Loss}^{\tilde{\alpha}}$. 
Table 1: Comparison between the Risk Aversion Measure and the Loss Aversion Measure

\begin{tabular}{|c|c|c|}
\hline & Risk Aversion: CRRA measure $(\gamma)$ & Loss Aversion $(\lambda)$ \\
\hline Domain & $\begin{array}{l}\gamma \text { measures the concavity of Bernoulli's } s \\
\text { utility function, which is defined over final } \\
\text { wealth (or consumption) }\end{array}$ & $\begin{array}{l}\lambda \text { measures, the concavity of Kahneman } \\
\text { and Tversky' } s \text { value function defined over } \\
\text { gain and loss }\end{array}$ \\
\hline $\begin{array}{l}\text { Example of a } \\
\text { survey } \\
\text { question }\end{array}$ & $\begin{array}{l}\text { Large amount gamble question (Barsky et } \\
\text { al., 1997): } \\
\text { (e.g.) Would you take a new job that has } \\
\text { a } 50-50 \text { chance of doubling your total } \\
\text { lifetime income or cutting it by a third? }\end{array}$ & $\begin{array}{l}\text { Small amount gamble question (Kahneman } \\
\text { and Tversky, 1992): } \\
\text { (e.g.) Would you agree to an investment } \\
\text { that has a } 50-50 \text { chance of receiving } \$ 200 \\
\text { or paying } \$ 100 \text { ? }\end{array}$ \\
\hline Features & $\begin{array}{l}\text { Attitude to risk under the deliberation } \\
\text { mode (system 2) or } \\
\text { attitude to risk in a comprehensively } \\
\text { inclusive context }\end{array}$ & $\begin{array}{l}\text { Attitude to loss under the intuition mode } \\
\text { (system 1) or } \\
\text { attitude to loss when correlations are } \\
\text { neglected (narrow framing) }\end{array}$ \\
\hline $\begin{array}{l}\text { Effect on } \\
\text { insurance }\end{array}$ & $\gamma \uparrow \rightarrow$ Insurance demand $\uparrow$ & $\lambda \uparrow \rightarrow$ Insurance demand $\downarrow$ \\
\hline Key theory & Expected utility theory & $\begin{array}{l}\text { Prospect theory } \\
\text { Narrow framing }\end{array}$ \\
\hline $\begin{array}{l}\text { Agent in } \\
\text { consideration }\end{array}$ & Perfectly rational agent & Boundedly rational agent \\
\hline
\end{tabular}

Notes: The insurance-savings model in this paper incorporates both $\gamma$ and $\lambda$. The relative importance of the two parameters on decision making is determined by a scaling factor $\hat{b}$.

person decides to buy insurance. (i.e., even though a person has a high magnitude of $\lambda$, he/she may be willing to buy insurance if $\gamma$ is large)

The term $\hat{b}$ is a scaling factor that reflects the degree of narrow framing or intuitive judgment. A high magnitude of $\hat{b}$ indicates that an individual's decision is significantly affected by the gain-loss value, which is in turn determined by $\lambda$. If $\hat{b}$ is zero, then this implies that a person's decision is not affected by $\lambda$ but determined solely by the CRRA parameter $\gamma$. Note that a boundedly rational consumer's utility in (2.2) includes the fully rational consumer's utility in (2.1). Specifically, a perfectly rational consumer's objective function (2.1) is a particular case of a boundedly rational consumer's objective function (2.2) where $\hat{b}$ is zero. In this regard, this paper deals with a more generalized problem. 


\section{Figure 3: Two Measures for Attitude toward Risk-or-loss in the Model}

(a) Bernoulli utility function

$$
u(w)=\frac{w^{1-\gamma}-1}{1-\gamma}
$$

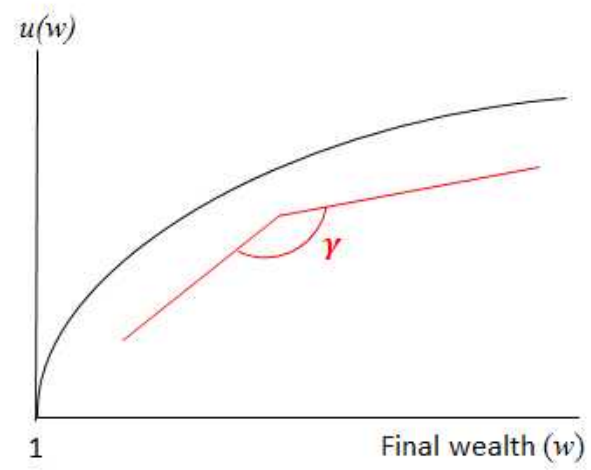

(b) Kahneman \& Tversky's value function

$$
v(x)=\left\{\begin{array}{lr}
x^{\alpha} & \text { if } x \geq 0 \\
-\lambda(-x)^{\tilde{\alpha}} \text { if } x<0
\end{array}\right.
$$

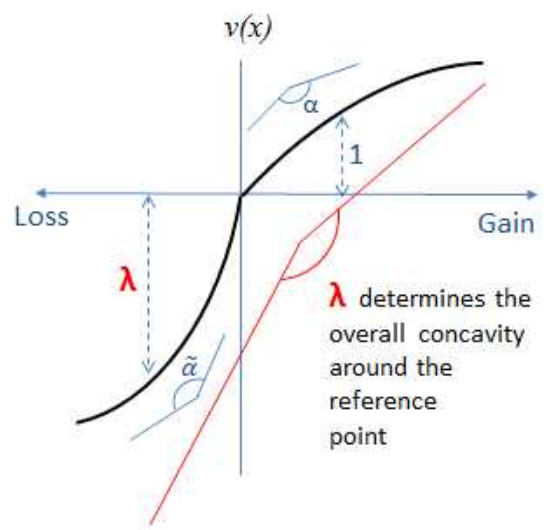

Notes: While the CRRA risk aversion measure $(\gamma)$ captures the concavity of Bernoulli's utility function (left), the loss aversion measure $(\lambda)$ captures the concavity of Kahneman and Tversky's value function (right). The model in this paper incorporates both $\gamma$ and $\lambda$. Source: Hwang (2016a)

The term $\hat{d}_{t}$ in (2.5) is the weighting function for bequests, which is commonly used in the related literature (e.g., Fischer, 1973). If $\hat{d}_{t}$ is one, this indicates that an individual attains the same level of utility from bequests as consumptions. A $\hat{d}_{t}$ of zero indicates that an individual does not value bequests.

Two assets are available in the economy in the first period: single-period term-life insurance and a riskless bond. The term $a_{t+1}(s 1)-$ or more precisely, $a_{t+1}\left(s^{t}, s_{t+1}=s 1\right)$ - represents the quantity of the single-period term-life insurance that pays out $a_{t+1}(s 1)$ units of consumption at $t+1$ if and only if $s 1$ is realized. The term $q_{t}$ - or more precisely, $q_{t}\left(s^{t}, s_{t+1}=s 1\right)$ - is the unit price of the term-life insurance. For example, if $q_{t}=0.5$ and $a_{t+1}(s 1)=2$, this means that a person abandons one unit of period t consumption $\left(1=0.5^{* 2}\right)$ in order for his/her heirs to receive two units of period $t+1$ consumption if $s 1$ is realized. The quantity of a riskless bond is denoted by $b_{t+1}$ (written in terms of the period $t$ consumption good). A positive value of $b_{t+1}$ means saving. No non-negativity 
restrictions are imposed on $a_{t+1}(s 1)$ or $b_{t+1}$. (Note that having negative holdings of $a_{t+1}(s 1)$ is analogous to buying annuities). There is, however, perfect enforcement of financial contracts. This asset market is complete because consumers can re-allocate resources across different states and periods by buying and selling $a_{t+1}(s 1)$ and $\left.b_{t+1} .5\right)$ Earnings at $t$ are denoted by $e_{t}$.

Consumers' budget constraints are as follows: 6 )

$$
\begin{aligned}
C_{t}+q_{t} \cdot a_{t+1}(s 1)+b_{t+1} & \leq e_{t} \\
Q_{t+1}(s 1) & \leq e_{t+1}(s 1)+a_{t+1}(s 1)+R_{t+1} \cdot b_{t+1} \\
C_{t+1}(s 2)+Q_{t+2}(s 2) & \leq e_{t+1}(s 2)+R_{t+1} \cdot b_{t+1}
\end{aligned}
$$

The units in all constraints are the consumption good.7) The budget constraint (2.6) illustrates that an individual decides how much to consume, buy term-life insurance, or buy riskless bonds, given the earnings in the first period. Inequalities (2.7) and (2.8) illustrate the constraints in the second period. If a person dies (i.e., $s_{t+1}=s 1$ ), then all of his/her assets become the bequests $\left(Q_{t+1}(s 1)\right)$. The assets include earnings $\left(e_{t+1}(s 1)\right.$, e.g., Social Security survivors benefits), death benefits of term-life insurance $\left(a_{t+1}(s 1)\right)$, and the principal and interests of bonds $\left(R_{t+1} \cdot b_{t+1}\right)$. Inequality (2.8) illustrates the case where a person survives at $t+1\left(i . e ., s_{t+1}=s 2\right)$ : the person decides how much to consume $\left(C_{t+1}(s 2)\right)$ and how much to set aside for bequests $\left(Q_{t+2}(s 2)\right)$.

A boundedly rational consumer's problem is as follows:

$$
\begin{gathered}
\max \\
c_{t}, a_{t+1}(s 1), b_{t+1}, Q_{t+1}(s 1), Q_{t+2}(s 2)
\end{gathered}
$$

subject to (2.6), (2.7), (2.8), $C_{t} \geq 0, C_{t+1}(s 2) \geq 0, Q_{t+1}(s 1) \geq 0$, and $Q_{t+2}(s 2) \geq 0$

5) The introduction of another type of insurance to the economy, for example $a_{t+1}(s 2)$, does not change the oplimal level of consumption or bequests.

6) Budget constraints hold with equality as strictly monotonic utility functions are assumed.

7) Note that if we assume an infinitely lived household without bequest motives, the budget constraint (2.6), (2.7) \& (2.8) can be generalized as follows:

$$
C_{t}\left(s^{t}\right)+\Sigma_{s_{t+1} \in s} q_{t}\left(s^{t}, s_{t+1}\right) \cdot a_{t+1}\left(s^{t}, s_{t+1}\right)+b_{t+1} \leq e_{t}\left(s^{t}\right)+a_{t}\left(s^{t}\right)+R_{t} \cdot b_{t}
$$

The above constraint is the standard budget constraint when sequential markets and uncertainties are considered, except for the case that a redundant asset, $b_{t+1}$, (which is the same as purchasing arrow securities $a_{t+1}$ for all possible states) is added. A similar budget constraint can be found in Dirk Kruger's macroeconomics textbook (p. 101 of "Macroeconomic Theory"). 
The Lagrangian and the first order conditions (FOC) for interior solutions are as follows: 8 )

(2.10) $L=U\left(C_{t}\right)+E_{t}\left[\hat{b} * v\left(a_{t+1}(s 1)\right)\right]+\pi_{1} \beta \widehat{d}_{t} U\left(Q_{t+1}(s 1)\right)+\pi_{2} \beta U\left(C_{t+1}(s 2)\right)+\pi_{2} \beta \widehat{d_{t+1}} U\left(Q_{t+2}(s 2)\right)$

$$
\begin{aligned}
& -\mu_{t} \cdot\left[\left(C_{t}\right)+q_{t} \cdot a_{t+1}(s 1)+b_{t+1}-e_{t}\right] \\
& -\mu_{t+1}(s 1) \cdot\left[\left(Q_{t+1}(s 1)-e_{t+1}(s 1)-a_{t+1}(s 1)-R_{t+1} \cdot b_{t+1}\right]\right. \\
& -\mu_{t+1}(s 2) \cdot\left[\left(C_{t+1}(s 2)-Q_{t+2}(s 2)-e_{t+1}(s 2)-R_{t+1} \cdot b_{t+1}\right]\right.
\end{aligned}
$$

$$
\left.U^{\prime}\left(C_{t}\right)\right)
$$$$
=\mu_{t}
$$

(2.15) $\left\{a_{t+1}(s 1)\right\} \quad q_{1} \mu_{t}-E_{t}\left[\hat{b} * v^{\prime}\left(a_{t+}(s 1)\right)\right]=\mu_{t+1}(s 1)$

(2.16) $\left\{b_{t+1}\right\} \quad R_{t+1}\left[\mu_{t+1}(s 1)+\mu_{t+1}(s 2)\right]=\mu_{t}$

The above FOCs can be summarized as follows:

(2.17) $q_{t} U^{\prime}\left(C_{t}\right)-E_{t}\left[\hat{b} * v^{\prime}\left(a_{t+}(s 1)\right)\right]=\pi_{1} \beta \widehat{d_{t}} U^{\prime}\left(Q_{t+1}(s 1)\right)$

(2.18) $\frac{1}{R_{t+1}} U^{\prime}\left(C_{t}\right)=\pi_{1} \beta \widehat{d_{t}} U^{\prime}\left(Q_{t+1}(s 1)\right)+\pi_{2} \beta U^{\prime}\left(C_{t+1}(s 2)\right)$

(2.19) $\frac{1}{R_{t+1}} U^{\prime}\left(C_{t}\right)=\pi_{1} \beta \widehat{d_{t}} U^{\prime}\left(Q_{t+1}(s 1)\right)+\pi_{2} \beta \widehat{d_{t+1}} U^{\prime}\left(C_{t+1}(s 2)\right)$

The intertemporal budget constraint summarizing (2.6), (2.7), and (2.8) is as follows:

(2.20) $C_{t}+q_{t} \cdot Q_{t+1}(s 1)+\left(\frac{1}{R_{t+1}}-q_{t}\right)\left[C_{t+1}(s 2)+Q_{t+2}(s 2)\right]=e_{t}+q_{t} \cdot e_{t+1}(s 1)+\left(\frac{1}{R_{t+1}}-q_{t}\right) \cdot e_{t+1}(s 2)$

\section{Optimal levels of saving and term-life insurance for perfectly rational agents $(i . e ., \hat{b}=0$ )}

By plugging the FOCs into (2.20), one can get optimal levels of consumption, bequests, and assets. We first look at a perfectly rational consumer's optimal choice by setting $\hat{b}=0$.

8) Since CRRA utility function satisfies inada conditions, $C^{*}>0$. And since CRRA with $\gamma>0$ is strictly concave, FOCs guarantee unique global max. 
(2.21)

$$
C_{t}^{*}=\frac{e_{t}+q_{t} e_{t+1}(s 1)+\frac{1-q_{t} R_{t+1}}{R_{t+1}} e_{t+1}(s 2)}{1+q_{t}\left(\frac{\beta \pi_{1}}{q_{t}} \widehat{d}_{t}\right)^{1 / \gamma}+\left(\frac{1-q_{t} R_{t+1}}{R_{t+1}}\right)^{1-1 / \gamma}\left(\beta \pi_{2}\right)^{1 / \gamma} \cdot\left\{1+\widehat{d_{t+1}} 1 / \gamma\right\}}
$$

$$
Q_{t+1}(s 1)^{*}=\left(\frac{\beta \pi_{1}}{q_{t}} \widehat{d}_{t}\right)^{1 / \gamma} \cdot C_{t}^{*}
$$

$$
C_{t+1}(s 2)^{*}=\left(\frac{R_{t+1}}{1-q_{t} R_{t+1}} \beta \pi_{2}\right)^{1 / \gamma} \cdot C_{t}^{*}
$$

$$
Q_{t+2}(s 2)^{*}=\left(\frac{R_{t+1}}{1-q_{t} R_{t+1}} \beta \pi_{2} \widehat{d_{t+1}}\right)^{1 / \gamma} \cdot C_{t}^{*}
$$

$a_{t+1}(s 1)^{*}=\left[\left(\frac{\beta \pi_{1}}{q_{t}} \widehat{d}_{t}\right)^{1 / \gamma}-\left(\frac{R_{t+1}}{1-q_{t} R_{t+1}} \beta \pi_{2}\right)^{1 / \gamma} \cdot\left\{1+{\widehat{d_{t+1}}}^{1 / \gamma}\right\}\right] \cdot C_{t}^{*}+e_{t+1}(s 2)-e_{t+1}(s 1)$

$$
=\frac{1}{R_{t+1}} \cdot\left[\left(\frac{R_{t+1}}{1-q_{t} R_{t+1}} \beta \pi_{2}\right)^{1 / \gamma} \cdot\left(1+\widehat{d_{t+1}}{ }^{1 / \gamma}\right)\right] \cdot C_{t}^{*}-\frac{1}{R_{t+1}} \cdot e_{t+1}(s 2)
$$

\section{Mossin's (1968) Theorem and Yaari's (1965) result}

Equation (2.25) shows a perfectly rational consumer's optimal level of term-life insurance. Note that if (i) premiums of term-life insurance are fair $\left(q_{t}=\beta \pi_{1}\right.$; here, it is also assumed that a subjective probability of survival is the same as the objective probability), (ii) a bequest motive is sufficient to be $\widehat{d_{t}}=\widehat{d_{t+1}}=1$, and (iii) the price motive for saving is neutral (i.e., $\beta \cdot R_{t+1}=1$ ), then Mossin's (1968) result holds: risk-averse individuals fully insure themselves if premiums are fair. Under such conditions, the optimal quantities of insurance and bond are $a_{t+1}(s 1)^{*}=e_{t+1}(s 2)-e_{t+1}(s 1)-C_{t}^{*} \quad$ and $\quad b_{t+1}^{*}=\frac{1}{R_{t+1}}$. $\left\{2 \cdot C_{t}^{*}-e_{t+1}(s 2)\right\}$. This leads to an allocation $C_{t}^{*}=Q_{t+1}(s 1)^{*}=C_{t+1}(s 2)^{*}=Q_{t+2}(s 2)^{*}$.

If we assume that there is no bequest motive $\left(\widehat{d_{t}}=\widehat{d_{t+1}}=0\right)$, while keeping the assumptions (i) \& (iii), then Yaari's (1965) full annuitization result holds: risk-averse individuals with no bequest motive fully annuitize their assets. Under these assumptions, the optimal quantities of insurance and bond are $a_{t+1}(s 1)^{* *}=e_{t+1}(s 2)-e_{t+1}(s 1)-C_{t}^{* *}$ and $\left.\quad b_{t+1}{ }^{* *}=\frac{1}{R_{t+1}} \cdot\left\{C_{t}^{* *}-e_{t+1}(s 2)\right\} .9\right)$ This leads to an allocation of and $C_{t}^{* *}=C_{t+1}(s 2)^{* *}>0$ and $Q_{t+1}(s 1)^{* *}=Q_{t+2}(s 2)^{* *}=0$, 
which means a full annuitization.

Although this three-period model of saving and term-life insurance is simple, it enables the analysis of various aspects of term-life insurance and saving $\left(b_{t+1}\right)$ :

(1) life cycle / permanent income motives for saving;

(2) precautionary motives for saving (Skinner, 1987);

(3) the effect of a bequest motive on life insurance and saving;

(4) the effect of loss aversion on life insurance and saving;

This paper focuses on "(4) the effect of loss aversion on life insurance and saving" while considering (1)-(3).

\section{Introduction of whole-life insurance}

Whole-life insurance serves as a saving instrument as well as insurance: whole-life insurance accumulates cash value, and consumers can withdraw money based on the reserved fund of the insurance policy (savings feature); furthermore, whole-life insurance pays out death benefits if the insured die (insurance feature). In the three-period model, purchasing whole-life insurance is the same as simultaneously purchasing term-life insurance and riskless bonds $\left(b_{t+1}\right)$. Formally, one can imagine $\widetilde{a_{t+1}}$ units of whole-life insurance that can be purchased at $\mathrm{t}$. Assume that the cash value of this insurance becomes $\widetilde{R} \cdot \widetilde{a_{t+1}}$ at $t+1$ and $\widetilde{R}^{2} \cdot \widetilde{a_{t+1}}$ at $t+2$. If the insured die at $t+2$ (i.e., $s_{t+1}=s 2$ ), then the insurance pays out death benefits of $\widetilde{R}^{2} \cdot \widetilde{a_{t+1}}$. If the insured die at $t+1$ (i.e., $\left.s_{t+1}=s 1\right)$, then the whole-life insurance pays out $(\theta+\widetilde{R}) \cdot \widetilde{a_{t+1}}$ units of consumption as death benefits. In this case, purchasing $\widetilde{a_{t+1}}$ units of whole-life insurance is the same as purchasing the same units of riskless bonds and purchasing $\theta \cdot \widetilde{a_{t+1}}$ units of term-life insurance.

9) Note that $C_{t}^{* *}>C_{t}^{*}$. 


\subsection{Testable implications of the model}

[Al] Increase in loss aversion $(\lambda)$ decreases the demand for term-life insurance $\left(a_{t+1}(s 1)^{*}\right)$

Al holds because loss aversion creates a negative gain-loss utility whenever an individual purchases term-life insurance. Hence loss aversion decreases the demand for term life insurance, $a_{t+1}(s 1)^{*}$.

FOCs show this prediction more clearly. Plugging (2.17) into (2.18) and (2.19) leads to the following equations:

$$
\begin{aligned}
& \frac{1}{R_{t+1} q_{t}} E_{t}\left[\hat{b}^{*} v^{\prime}\left(a_{t+1}(s 1)\right)\right]=\pi_{2} \beta U^{\prime}\left(C_{t+1}(s 2)\right)-\left(\frac{1-R_{t+1} q_{t}}{R_{t+1} q_{t}}\right) \pi_{1} \beta \widehat{d}_{t} U^{\prime}\left(Q_{t+1}(s 1)\right) \\
& \frac{1}{R_{t+1} q_{t}} E_{t}\left[\hat{b}^{*} v^{\prime}\left(a_{t+1}(s 1)\right)\right]=\pi_{2} \beta \widehat{d_{t+1}} U^{\prime}\left(Q_{t+2}(s 2)\right)-\left(\frac{1-R_{t+1} q_{t}}{R_{t+1} q_{t}}\right) \pi_{1} \beta \widehat{d_{t}} U^{\prime}\left(Q_{t+1}(s 1)\right)
\end{aligned}
$$

To figure out how loss aversion affects $E_{t}\left[\hat{b}^{*} v^{\prime}\left(a_{t+1}(s 1)\right)\right]$, we first look at $E_{t}\left[\hat{b}^{*} v\left(a_{t+1}(s 1)\right)\right]$ which is the expected gain-loss value when purchasing $a_{t+1}(s 1)$ units of term-life insurance. A potential gain of the insurance is the present value of the net benefits from the insurance company $\left(\beta a_{t+1}(s 1)-q_{t} a_{t+1}(s 1)\right)$. The gain is realized if $s_{t+1}=s 1$. A potential loss of the insurance is the premium paid $\left(q_{t} a_{t+1}(s 1)\right)$. The loss is realized if $s_{t+1}=s 2$ Hence, the expected gain-loss value is as follows:

$$
E_{t}\left[\hat{b} v\left(a_{t+1}(s 1)\right)\right]=\hat{b}\left[\pi_{1} \cdot\left\{\beta a_{t+1}(s 1)\right\}^{\alpha}-\pi_{2} \lambda \cdot\left\{q_{t} a_{t+1}(s 1)\right\}^{\tilde{\alpha}}\right]
$$

Thus, if we take derivatives with respect to $a_{t+1}(s 1)$, then we have

$$
E_{t}\left[\hat{b} v^{\prime}\left(a_{t+1}(s 1)\right)\right]=\hat{b}\left[\alpha \pi_{1}\left(\beta-q_{t}\right)\left\{\beta a_{t+1}(s 1)-q_{t} a_{t+1}(s 1)\right\}^{\alpha-1}-\tilde{\alpha} \pi_{2} \lambda q_{t}\left\{q_{t} a_{t+1}(s 1)\right\}^{\tilde{\alpha}-1}\right]
$$

Hence, an increase in $\lambda$ decreases the marginal gain-loss value (left-hand-side (LHS) of (27)). To keep the equality, the right-hand-side (RHS) of (2.27) must decrease. This means that $U^{\prime}\left(Q_{t+1}(s 1)\right)$ should increase relative to $U^{\prime}\left(C_{t+1}(s 2)\right)$. (Note that $\left(\frac{1-R_{t+1} q_{t}}{R_{t+1} q_{t}}\right)$ is a positive value). To increase the marginal utility of a bequest in the case of death at $t+1\left(Q_{t+1}(s 1)\right)$ relative to that of consumption in the case of survival $\left(C_{t+1}(s 2)\right)$, the level of bequest 
$\left(Q_{t+1}(s 1)\right)$ should decrease relative to the consumption $\left(C_{t+1}(s 2)\right)$. Similarly, equation (2.28) implies that the level of a bequest at $t+1,\left(Q_{t+1}(s 1)\right)$ should decrease relative to the level of a bequest at $t+2\left(Q_{t+2}(s 2)\right)$. Budget constraints (2.7) and (2.8) imply that decreasing $Q_{t+1}(s 1)$ relative to $C_{t+1}(s 2)$ and $Q_{t+2}(s 2)$ can be attained by decreasing term-life insurance. That is, the transfer of resources from state $s 1$ to state $s 2$ can be accomplished by reducing term-life insurance holdings.

\section{[A2] An increase in loss aversion $(\lambda)$ increases savings $\left(b_{t+1}\right)$}

This means that loss-averse individuals save more in order to use savings as a financial buffer against potential bad events in the future instead of using term-life insurance as a financial buffer. FOC (2.18) provides the rationale for this. Equation (2.18) implies that marginal cost of giving up today's consumption should be the same as the expected marginal benefits of tomorrow's bequest and consumption. Suppose $a_{t+1}(s 1)$ decreases or becomes zero because of a high loss-aversion. This leads to an increase in today's consumption $\left(C_{t}\right)$ and a decrease in the bequest for $s 1, Q_{t+1}(s 1)$. Hence, the LHS of (2.18) decreases, while the first term in the RHS increases. To maintain equality, the second term in the RHS (the marginal utility of tomorrow's consumption) should decrease. Hence, the level of tomorrow's consumption, $C_{t+1}(s 2)$, should increase. This is done by increasing savings $\left(b_{t+1}\right)$. Similar logic applies to the FOC (2.19) and leads to the same conclusion.

[A3] Loss aversion has less impact on the take-up of whole-life insurance than on term-life insurance.

This is because whole-life insurance serves as a saving instrument as well. Even if $s_{t+1}=s 2$ is realized, the insured can still withdraw money based on the reserved fund of the whole-life insurance policy. Hence, the potential loss from whole-life insurance is smaller than that from term-life insurance. 
[A4] The weights for bequests $\left(\widehat{d_{t}}, \widehat{d_{t+1}}\right)$ have different impacts on term-life insurance and saving. An increase in $\widehat{d_{t}}$ increases the demand for term-life insurance, while it decreases the demand for saving $\left(b_{t+1}\right)$. In contrast, an increase in $\widehat{d_{t+1}}$ decreases the demand for term-life insurance, while it increases the demand for saving $\left(b_{t+1}\right)$.

The weight, $\widehat{d_{t}}$ represents the desire for leaving bequests in the event of an unexpected premature death $\left(\widehat{d_{t}}\right)$, while $\widehat{d_{t+1}}$ represents the desire for leaving bequests for an expected death at a later time.

An increase in $\widehat{d_{t}}$ increases the demand for term-life insurance, while it decreases the demand for saving $\left(b_{t+1}\right)$. This is because a transfer of resources to the state of premature death $(s 1)$ is made by term-life insurance. A formal proof is provided in Appendix B.

In contrast, an increase in $\widehat{d_{t+1}}$ decreases the demand for term-life insurance, while it increases the demand for saving $\left(b_{t+1}\right)$. This is because a transfer of resources to state $s 2$ can be attained by reducing term-life insurance and increasing savings.

[A5] The effect of loss aversion on the demand for term-life insurance is amplified by the degree of narrow framing $(\hat{b})$ and the expected survival probability $\left(\pi_{2}\right)$.

Equation (2.30) shows this prediction clearly. Since the scaling factor, $\widehat{b}$, determines the degree to which the gain-loss value affects individuals' decisions, a high magnitude of $\hat{b}$ implies a high impact of loss aversion $(\lambda)$ on insurance take-up. And since the potential loss is associated with $s_{t+1}=s 2$, the subjective probability of experiencing $s 2\left(\pi_{2}\right)$ affects the impacts of loss aversion. 


\section{Empirical Tests Using the Health and Retirement Study}

\subsection{Loss aversion data}

The degree of loss aversion, which is formally defined by $\lambda=\frac{-v(-x)}{v(x)}$, captures the relative sensitivity to losses compared with the same amount of gains. Kahneman and Tversky (1992) measure loss aversion using small-amount risky gamble questions (e.g., accept or turn down a prospect that has a 50-50 chance of losing \$100 or winning \$202). 10) This paper uses a similar question.

This paper uses the Health and Retirement Study (HRS) Public Data. The HRS is a longitudinal panel survey that interviews a representative sample of approximately 20,000 Americans over the age of 50 every two years (HRS webpage). While regularly collecting detailed information on respondents' assets and health status, the HRS also conducts a one-time survey on special topics called an 'experimental module' (experimental modules are also publicly available). Survey questions about respondents' attitudes toward small-amount risky investments are included in the Prospect Theory Module of the 2012 HRS. Details of the Prospect Theory Module are explained in the principal investigators' study on narrow framing and long-term care insurance (Gottlieb and Mitchell, 2015). Specifically, this paper uses the following questions, which are randomly assigned to about 1,900 HRS respondents: 11)

"Suppose that a relative offers you an investment opportunity for which there is a $50-50$ chance you would receive [ $\$ 103$ or have to pay $\$ 100]$.

10) The theoretical foundation of the loss aversion measure is discussed in Rabin (2000), Rabin and Thaler (2001), and Barberis, Huang and Thaler (2006). These studies prove that subjects' behavior of turning down a small favorable prospect cannot be rationalized without introducing subjects' neglect of the diversification effect that the prospect may bring. In the HRS sample, approximately $94.4 \%$ of respondents turn down the Receive-\$103-or-Pay- $\$ 100$ investment, suggesting that they tend to neglect correlation. Hence, for at least $94.4 \%$ of respondents, the small-amount-risky-investment-questions in this paper capture how individuals assess gain and loss when correlations are neglected. This feature allows the questions to measure loss aversion as defined by Kahneman and Tversky (1992).

11) Technically, not all seven questions are asked to respondents. All respondents are first asked '(4) Receive $\$ 115$ or pay $\$ 100$ ' question. If a respondent agrees to this investment, then, '(2) Receive $\$ 107$ or pay $\$ 100$ ' is asked. If a respondent does not agree to the initial question (4), then '(6) Receive $\$ 130$ or pay $\$ 100$ ' is asked. Similar rules are applied to the subsequent questions. For details, see Gottlieb and Mitchell (2015). 
Table 2: Estimation Results of Loss Aversion $(\lambda)$

\begin{tabular}{lccccc} 
Risky Investments & \begin{tabular}{c} 
Those who accept the \\
investment but rejects other \\
less favorable investment offers \\
\cline { 2 - 4 } (percent)
\end{tabular} & $\begin{array}{c}\text { Range of } \\
\text { Implied } \\
\text { Loss Aversion }\end{array}$ & $\begin{array}{c}\text { Selected } \\
\text { Loss Aversion }\end{array}$ \\
(1) Receive $\$ 103$ or pay $\$ 100$ & 95 & $(5.6)$ & $\lambda \leq 1.03$ & 1.015 \\
(2) Receive $\$ 107$ or pay $\$ 100$ & 22 & $(1.3)$ & $1.03<\lambda \leq 1.07$ & 1.05 \\
(3) Receive $\$ 110$ or pay $\$ 100$ & 5 & $(0.3)$ & $1.07<\lambda \leq 1.10$ & 1.085 \\
(4) Receive $\$ 115$ or pay $\$ 100$ & 66 & $(3.9)$ & $1.10<\lambda \leq 1.15$ & 1.125 \\
(5) Receive $\$ 120$ or pay $\$ 100$ & 24 & $(1.4)$ & $1.15<\lambda \leq 1.20$ & 1.175 \\
(6) Receive $\$ 130$ or pay $\$ 100$ & 24 & $(1.4)$ & $1.20<\lambda \leq 1.30$ & 1.25 \\
(7) Receive $\$ 300$ or pay $\$ 100$ & 323 & $(19.0)$ & $1.30<\lambda \leq 3.00$ & 2.15 \\
Reject 'Receive $\$ 300$ or pay $\$ 100$ ' & 1,139 & $(67.1)$ & $\lambda>3.00$ & 3.15 \\
\hline Total & 1,698 & $(100.0)$ & - & - \\
\hline
\end{tabular}

Source: HRS 2012, Prospect Theory Module

Would you agree to this investment?
(1) Receive $\$ 103$ or pay $\$ 100$
(2) Receive $\$ 107$ or pay $\$ 100$
(3) Receive $\$ 110$ or pay $\$ 100$
(4) Receive $\$ 115$ or pay $\$ 100$
(5) Receive $\$ 120$ or pay $\$ 100$
(6) Receive $\$ 130$ or pay $\$ 100$
(7) Receive $\$ 300$ or pay $\$ 100 ”$

Among the selected sample of 1,900 elderly people, 1,698 complete the survey. Table 2 shows the results. Nineteen percent of the respondents reject investments (1)-(6) but accept the investment (7), indicating that their loss aversion is greater than 1.3 and equal to or less than 3.0. For these individuals, loss aversion of 2.15 (average of 1.3 and 3.0) is assigned. Approximately two thirds of the respondents reject all seven risky investments, indicating that their loss aversion is greater than 3.0. As a result, the median of $\lambda$ is estimated to be higher than three, which is higher than Kahneman and Tversky's estimation result (median of $\lambda=2.25$ ). It seems that this high loss aversion is associated with the sample of the HRS, which only surveys the elderly (aged 51 or more), who, in general, have a more conservative attitude toward loss than the young.

Table A.4 (Appendix) presents the degree of loss aversion by demographics. Although there is no statistical significance, females, those aged 70 or older, less 
educated people, and those with fewer children tend to be more loss-averse. Risk aversion, which is based on the status-quo-bias-free lifetime income gamble questions (Barsky et al., 1997), shows a similar pattern.

\subsection{Life insurance ownership and wealth data}

Detailed information on the definitions, sources, and characteristics of the data is reported in Table A.1-A.3 (Appendix). Life insurance ownership information is based on the following questions from the 2012 HRS $(\mathrm{N}=18,712)$ :

(i) "Do you have any life insurance, including individual or group policies? IWER: Do not include burial insurance." (HRS code: NT011)

(ii) "How many different life insurance policies do you have?

IWER: Include individual policies, group policies, or paid-up policies if $\mathrm{R}$ asks.” (NT012)

(iii) "[What/Altogether, what] is the total face value of [this policy/these policies], that is, the amount of money the beneficiary would get if you were to die?" (NT013)

The HRS also collects ownership information about whole-life insurance.

(iv) "[Is this a life insurance policy that builds/Are any of these life insurance policies ones that build] up a cash value that you can borrow against, or that you would receive if the policy were to be cancelled?

Def: (These are sometimes called 'Whole Life' or 'Straight Life Policies.')" (NT018)

(v) "How many such policies do you have?" (NT019)

(vi) "What is the current face value of [these policies/this policy]?" (NT020)

Since the 2012 HRS does not survey the ownership of term-life insurance, we estimate term-life insurance ownership information based on the fact that life insurance is either term-life or whole-life insurance. For example, suppose a 
respondent answers that he/she has two life insurance plans, and their total face value is $\$ 20,000$. If the person answers that he/she has one whole-life insurance plan whose face value is $\$ 12,000$, then the person is assumed to have one term-life insurance plan whose face value is $\$ 8,000$.

To examine if the estimated ownership data on term-life insurance is reasonable, the estimated data is compared with a data set based on real interviews on term-life insurance holdings. The 1993 HRS (AHEAD survey) interviews those aged 70 or older about ownership of term-life insurance (for details, see Brown 2001). The questions on ownership of term-life insurance are discontinued after the 1993 survey. Although there is a considerable time gap between the two surveys (2012 vs.1993), given the scarcity of individual-level term-life insurance ownership data, this is one feasible way to assess if our estimated data is reasonable. In the 1993 HRS, the ownership rate of term-life insurance among married men and women aged 70 and older is 41.74 and 30.14 percent respectively. In the 2012 HRS, the estimated ownership rate of term-life insurance among married men and women aged 70 and older is 37.51 and 26.09 percent respectively. Considering the time gap, it seems that the difference falls within an acceptable range. Both data show that roughly one third of those aged 70 or older own term-life insurance, indicating that many U.S. elderly utilize the renewal option of term-life insurance. ${ }^{12)}$

In the 2012 HRS data as a whole (aged 51 and older), 56.0 percent of people are found to hold life insurance: 38.0 percent own term-life insurance and 25.4 percent own whole-life insurance. Among them, 7.4 percent own both term-life and whole-life insurance (see Table 3). The median of the total face value conditional on owning any life insurance is $\$ 45,000$, and the conditional average of the total face value is $\$ 116,105$. Life insurance owners have on average 1.54 life insurance plans. In the case of term life insurance, the median

12) Considering that one primary goal of life insurance is to protect family against the loss of a primary wage earner, which is especially true in the case of term-life insurance, the elderly's owning of (term-) life insurance raises questions regarding their motives since most elderly people do not earn wage income. Regarding this question, Brown (2001) has discussed various reasons: (1) protection of the spouse against loss of pension or Social Security income, (2) residue from a past attempt during working-age to protect human capital, (3) tax planning, and (4) covering funeral expenses (p. 117). 
Table 3: Life Insurance Ownership of the U.S. Elderly in 2012 (Age $\geq 51$ )

\begin{tabular}{lccc} 
& Any life insurance & Term-life & Whole-life \\
Ownership rate (own=1) & 0.560 & 0.380 & 0.254 \\
Amount I Own & & & \\
$\quad$ Medican (\$) & $\$ 45,000$ & $\$ 50,000$ & $\$ 30,000$ \\
Mean (\$) & $\$ 116,105$ & $\$ 124,589$ & $\$ 75,005$ \\
Average number of plans | Own & 1.54 & 1.37 & 1.33 \\
\hline
\end{tabular}

Note: Unweighted data.

Source: HRS 2012

of the total face value conditional on holding any term-life plan is $\$ 50,000$, and the conditional average of the total face value is $\$ 124,589$.

Detailed ownership information in Table A.5 (Appendix) shows that wealthy, highly-educated, male, and married individuals, as well as those with children, are more likely to hold a life insurance policy.

One important limitation of the HRS data is that it does not distinguish if a respondent's life insurance policy is an individual policy or a group policy. Since many employers provide term-life insurance as a part of a workplace benefits package, this limitation could be a confounding factor in investigating how individual's behavioral tendencies affect insurance buying decisions. To alleviate this issue, we take the following approaches. First, the analysis is restricted to those aged 60 or older in all regressions, so that our samples are less affected by the employer-provided term-life policies, which are tied to employment (of those aged 60 or older in the HRS sample, only 20.26 percent are employed). Second, an indicator variable is added to determine whether the respondent is currently working in all regressions. Third, for the robustness check, occupation dummies (to the respondent's job with the longest reported tenure ${ }^{13)}$ ) are added. Fourth, whether or not loss aversion is associated with the probability of "holding two or more plans of term-life insurance" and with the

13) Employer-provided term-life insurance has a renewal option, which means that those who retire may keep term-life coverage if they decide to pay premiums by themselves. Hence, retirees' term-life ownership can be affected by past employment history. Control for the past occupation history can alleviate this issue. 
Table 4: Median Levels of Household Wealth by Age Group in 2012 (Nominal Dollars)

\begin{tabular}{lccccc} 
(Number of Households) & $\begin{array}{c}\text { Age } 51-59 \\
(3,732)\end{array}$ & $\begin{array}{c}60-69 \\
(3,095)\end{array}$ & $\begin{array}{c}70-79 \\
(3,048)\end{array}$ & $\begin{array}{c}80-89 \\
(1,503)\end{array}$ & $\begin{array}{c}90-99 \\
(413)\end{array}$ \\
Stock & 0 & 0 & 0 & 0 & 0 \\
House & 20,000 & 60,000 & 80,000 & 79,000 & 0 \\
Nonrisky & 1,000 & 2,500 & 5,000 & 10,000 & 6,000 \\
Net Fin Worth & 0 & 2,000 & 7,975 & 18,450 & 10,000 \\
Net Worth & 50,000 & 111,500 & 160,000 & 173,800 & 79,000 \\
\hline
\end{tabular}

Note: Unweighted cross-section data in 2012.

Nonrisky = value of checking, savings, or money market accounts + value of CDs, government savings bonds, \& T-bills + net value of bonds and bond funds.

Net Fin Worth $=$ Stock + Nonrisky + net value of all other saving value of other debt (other than mortgages, land loans, or home loans).

Net Worth $=$ Net Fin Worth + House + Net Value of Secondary Residence .

Source: RAND HRS Income and Wealth Imputations-version O (March 2016)

amount of "face value $\$ 50,000$ " is tested based on the fact that employer-provided term-life policies are typically limited to one plan with a face value of $\$ 50,000$.

Five variables are used for household wealth levels in 2012: Stock, House, Nonrisky, Net Fin Worth, and Net Worth. The source of these wealth variables is the RAND HRS Income and Wealth Imputations-Version O (March 2016). Stock is the net value of stocks, mutual funds, and investment trusts that a household owns (RAND HRS code: H11WSTCK). House is a net value of primary residence (H11WTOTH). Nonrisky is the sum of the "value of checking, savings, or money market accounts,' 'value of CDs, government savings bonds, and T-bills,' and the 'net value of bonds and bond funds.' (H11WCHCK+H11WCD+H11WBOND). Net Fin Worth is the net value of non-housing financial wealth (H11WTOTN $=$ Stock + Nonrisky + net value of all other saving - value of other debt (other than mortgages, land loans, or home loans)). Net Worth is total net wealth including secondary residences $($ H11WTOTB $=$ Net Fin Worth + House + Net Value of Secondary Residence $)$.

Table 4 reports five wealth variables by age group. One important pattern to note is that elderly households increase their wealth level even after retirement (so called savings puzzle): those aged 70-79 have a higher net worth level than those aged 60-69; those aged 80-89 have an even higher net worth level. This 
wealth accumulation pattern is not consistent with the predictions of the permanent income / life cycle model of saving, which predicts a substantial dissaving after retirement.

\subsection{Loss aversion and term-life insurance \& whole-life insurance}

\subsubsection{Descriptive statistics}

To control for employer-provided term-life insurance and the life cycle effect of saving, we restrict our sample to those 60 and older. When one uses all samples of the HRS (i.e., those 51 and older), however, one can also find a similar empirical result, i.e., a negative association between loss aversion and the take-up of term-life insurance as reported in Table A.6 (Appendix).

Panel A of Table 5 shows that loss aversion is significantly negatively correlated with the term-life insurance holdings and positively correlated with the household's wealth. These results are consistent with the prediction [A1]-[A2] in the previous section. Specifically, the high loss-aversion group shows a significantly lower ownership rate of term-life insurance than the low loss-aversion group (34.2\% vs. $41.5 \%)$. In terms of both the number of term-life insurance policies (0.448 vs. 0.573 ) and the total coverage amount of term-life insurance (logged value: $2.950 \mathrm{vs}$. 4.031), the high loss-aversion group has significantly lower figures. In contrast, being highly loss averse or not does not show a statistically significant association with whole-life insurance, which is a combination of insurance and savings. If we look at the pure savings side, Net Financial Worth and Net Worth are positively correlated with loss aversion. This is consistent with the model, which predicts that loss aversion may increase precautionary saving. Figure 4 illustrates main results.

Except for gender, there is no measurable difference in demographics between the low loss-aversion and high loss-aversion groups in terms of cognitive ability, education, marital status, and the number of children.

Panel B of Table 5 reports ownership information for term-life and whole-life insurance, conditional on owning any type of life insurance. Loss aversion is significantly negatively correlated with term-life insurance holdings and weakly positively correlated with whole-life insurance. 
Figure 4: Loss Aversion, Ownership of Term-life \& Whole-life Insurance, and Wealth $($ Age $\geq 60)$

a. Own Term-life Insurance

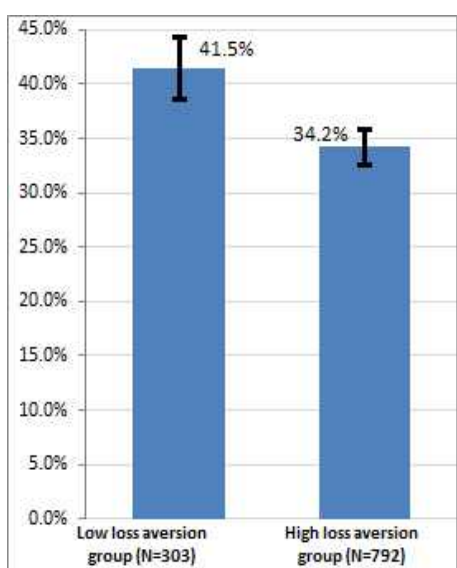

b. Own Whole-life Insurance

c. Log Net Worth

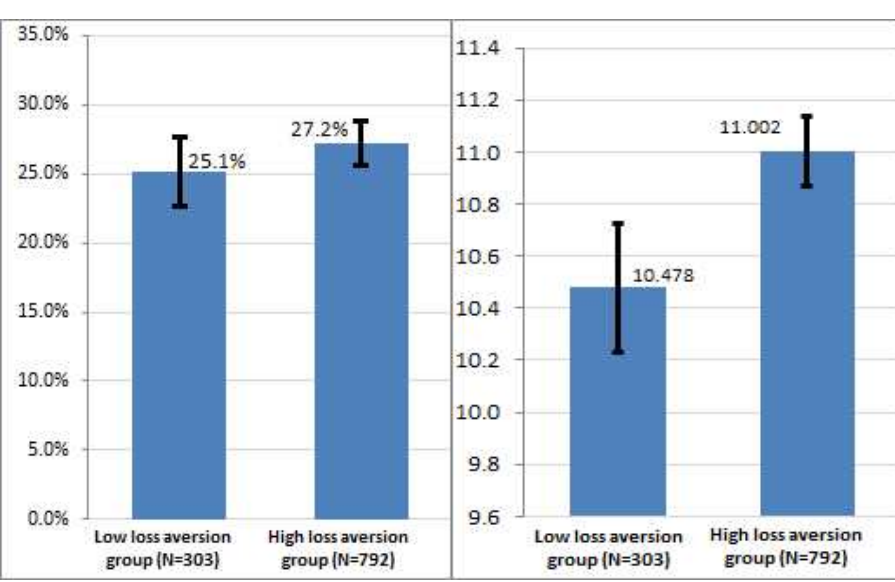

Notes: Figure a [b] illustrates the ownership rate of term-life insurance [whole-life insurance] among the low loss aversion group $(\lambda \leq 2.15, N=303)$ and the high loss aversion group $(\lambda=3.15, \quad N=792)$. Figure $c$ illustrates the average of Log Net Worth among the low loss aversion group $(\lambda \leq 2.15)$ and the high loss aversion group $(\lambda=3.15)$. The error bars indicate the standard errors in Table 5. The high loss-aversion group shows a significantly lower ownership rate of term-life insurance (=pure insurance) than the low loss-aversion group (34.2\% vs. $41.5 \%)$. The high loss-aversion group shows a weakly higher ownership rate of whole-life insurance (= partial insurance + partial savings) than the low loss-aversion group ( $27.2 \%$ vs. $25.1 \%$ ). The high loss-aversion group holds a significantly higher level of net worth (=savings) than the low loss-aversion group (logged value 11.002 vs 10.478). These results are consistent with the prediction that loss aversion depresses insurance demand and stimulates savings. 
Table 5: Loss Aversion, Term-life and Whole-life Insurance, and Wealth (Age $\geq 60$ )

Panel A. HRS sample aged 60 or more

\begin{tabular}{|c|c|c|c|c|c|}
\hline \multirow{4}{*}{$\begin{array}{l}\text { own_life } \\
\text { num_life } \\
\text { log_amt_life }\end{array}$} & \multicolumn{2}{|c|}{$\begin{array}{c}\text { Those with low } \\
\text { loss aversion }(\lambda \leq 2.15) \\
N=303\end{array}$} & \multicolumn{2}{|c|}{$\begin{array}{c}\text { Those with high } \\
\text { loss aversion }(\lambda=3.15) \\
N=792\end{array}$} & \multirow{2}{*}{$\begin{array}{c}\text { Two tailed t-test for } \\
\text { equal mean } \\
\text { p-value } \\
0.3553\end{array}$} \\
\hline & 0.594 & $(0.028)$ & 0.563 & $(0.018)$ & \\
\hline & 0.917 & $(0.057)$ & 0.828 & $(0.034)$ & 0.1723 \\
\hline & 5.916 & $(0.312)$ & 5.198 & $(0.192)$ & $0.0475^{* *}$ \\
\hline own_term & 0.415 & $(0.029)$ & 0.342 & $(0.017)$ & $0.0275^{* *}$ \\
\hline num_term & 0.573 & $(0.047)$ & 0.448 & $(0.026)$ & $0.0153^{* *}$ \\
\hline log_amt_term & 4.031 & $(0.311)$ & 2.950 & $(0.176)$ & $0.0016^{* * *}$ \\
\hline own_whole & 0.251 & $(0.025)$ & 0.272 & $(0.016)$ & 0.5018 \\
\hline num_whole & 0.323 & $(0.037)$ & 0.358 & $(0.025)$ & 0.4442 \\
\hline log_amt_whole & 1.144 & $(0.210)$ & 1.031 & $(0.123)$ & 0.6333 \\
\hline log_Stock & 2.752 & $(0.285)$ & 2.525 & $(0.170)$ & 0.4856 \\
\hline log_House & 8.398 & $(0.297)$ & 8.684 & $(0.183)$ & 0.4117 \\
\hline log_Nonrisky & 7.095 & $(0.256)$ & 7.535 & $(0.149)$ & 0.126 \\
\hline log_Net Fin Worth & 6.841 & $(0.305)$ & 7.483 & $(0.177)$ & $0.0616^{*}$ \\
\hline log_Net Worth & 10.478 & $(0.245)$ & 11.002 & $(0.134)$ & $0.0475^{* *}$ \\
\hline cognitive & 518.0 & $(2.07)$ & 516.2 & (1.33) & 0.4623 \\
\hline edu & 12.78 & $(0.187)$ & 12.58 & $(0.105)$ & 0.3251 \\
\hline married & 0.561 & $(0.028)$ & 0.575 & $(0.018)$ & 0.6708 \\
\hline female & 0.534 & $(0.029)$ & 0.610 & $(0.017)$ & $0.0225^{* *}$ \\
\hline kids & 3.302 & $(0.118)$ & 3.224 & $(0.074)$ & 0.5790 \\
\hline
\end{tabular}

Panel B. Samples are restricted to those who own any type of life insurance (Age $\geq 60$ )

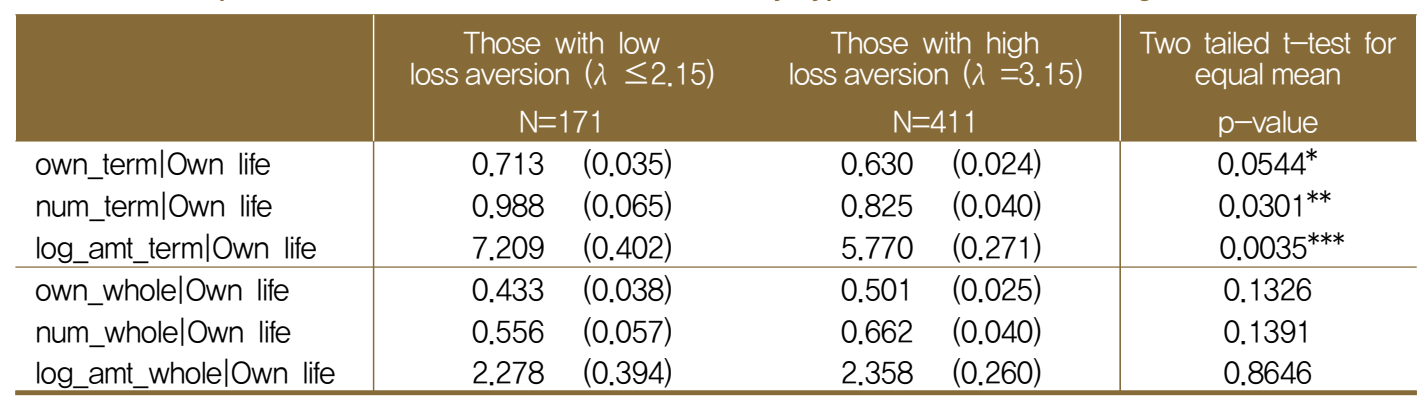

Notes: The values are the average of each group. Standard errors in parentheses. $* * * p<0.01, * *$ $\mathrm{p}<0.05, * \mathrm{p}<0.1$. own_life (own_term, own_whole) is an indicator variable if a respondent owns any life insurance (term-life insurance, whole-life insurance). num_life (num_term, num_whole) is the number of any life insurance (term-life insurance, whole-life insurance) a respondent holds. log_amt_life (log_amt_term, log_amt_whole) is the natural log of 'the face value of life insurance (term-life insurance or whole life insurance) +1 '. cognitive is a respondent's total score on the quantitative number series of the HRS. edu is years of education. log_Stock (log_House, log_Nonrisky, log_NetFinWorth, log_NetWorth) is the natural log of 'Stock (House, Nonrisky, NetFinWorth, NetWorth) +1 ' (The value in the log is replaced with one if the original value is less than one).

Sources: 2012 HRS, RAND HRS Income and Wealth Imputations-Version O (March 2016) 


\subsubsection{Regression results 1: loss aversion, term-life and whole-life insurance}

Our estimating equations are as follows:

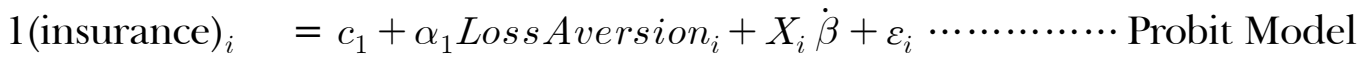

Number_of_insu ${ }_{i}=c_{2}+\alpha_{2}$ LossAversion $_{i}+X_{i} \ddot{\beta}+e_{i} \cdots \cdots \cdots \cdots$ OLS

Log_amount_insu ${ }_{i}=c_{3}+\alpha_{3}$ Loss_Aversion $_{i}+X_{i} \beta^{\cdots}+u_{i} \cdots \cdots \ldots$. Tobit Model

where 1 (insurance) ${ }_{i}$ is an indicator variable for whether an individual $i$ owns term-life (or whole-life) insurance, Number_of insu $_{i}$ is the number of term-life (or whole-life) insurance policies that the individual owns, Log_amount_insu ${ }_{i}$ is "the natural $\log$ of the total face value of the term-life (or whole-life) insurance that the individual owns +1 ,' and $X_{i}$ denotes control variables. The Tobit model is employed for the last equation because Log_amount_insu ${ }_{i}$ is left-censored at zero. Note that a person's desire for insurance protection can be measured using the face value of insurance only if the person owns life insurance. If the person does not own life insurance, then the measure of the desire is unduly coded as zero. Hence, the Tobit model is appropriate.

Estimation results in Table 6 indicate that loss aversion is significantly negatively associated with ownership of term-life insurance and weakly positively associated with whole-life insurance, which is consistent with the predictions [A1] and [A3] of the model. Columns (1)-(3) in the Panel B of Table 6 show that the negative association between loss aversion and term-life insurance ownership holds after controlling for various factors including bequest motives (if one has a written will, the number of children, and marital status), age, gender, income, wealth, education, and employment status. Columns (4)-(6) of Table 6 report that loss aversion is positively associated with whole-life insurance holdings, but the relationship is not statistically significant.

Table 6 indicates that loss aversion has an economically meaningful effect on the ownership probability of term-life insurance and a large effect on the coverage amount of term-life insurance. If the marginal effect of loss aversion is calculated at means of explanatory variables using column (1) of Panel B in Table 6, the marginal effect is calculated to be -0.036 . This indicates that a one-unit change in loss aversion decreases the probability of owning term-life 
insurance by 3.6 percent point. Although the figure, -3.6 percent point, is itself not large, considering that the ownership probability of term-life insurance is only 36.0 percent in the sample, it is appropriate to interpret that loss aversion has economically meaningful effects on term-life insurance holdings. Column (2) of Panel B indicates that a one-unit change in loss aversion decreases the number of term-life policies by 0.0674. Column (3) of Panel B in Table 6 indicates an economically large impact of loss aversion on the coverage amount of term-life insurance. Column (3) reports that a unit increase in loss aversion decreases the coverage amount by 133.7 percent.

Table 7 reports the regression results when samples are restricted to those who own any type of life insurance. It shows that not only term-life insurance, but also whole-life insurance, has a statistically significant relationship with loss-aversion. Columns (4)-(5) show that the positive association between whole-life insurance ownership and loss-aversion becomes statistically significant when we focus on the choices between term-life and whole-life insurance. The marginal effects of loss-aversion measured at means of explanatory variables of Table 7 are as follows: for those who own any type of life insurance, a one-unit change in loss aversion marginally decreases (increases) the probability of owning term-life (whole-life) insurance by 5.83 (6.60) percent point if the marginal effect is measured at means of explanatory variables. And one-unit increase in loss aversion decreases (increases) the number of term-life (whole-life) policies by 0.115 (0.094), and decreases (increases) the desired coverage amount of term-life (whole-life) by 118.2 (156.6) percent point.

The effect of a bequest motive on term-life and whole-life insurance appears to be in line with the prediction [A4] of the model: the desire for leaving bequests for an expected death at a later time $\left(\widehat{d_{t+1}}\right)$ increases the demand for saving. Table 6 and Table 7 report that the bequest motive as measured by an indicator variable if an individual has a written will is positively associated with whole-life insurance. Although the act of writing a will is open to interpretation, when the problem is narrowed down as to whether the act is associated with $\hat{d}_{t}$ or $\widehat{d_{t+1}}$, it is reasonable to interpret that the act is associated with $\widehat{d_{t+1}}$. 
An indicator variable for being currently employed is estimated to be significantly positively associated with term-life insurance but not with whole-life insurance. This result is consistent with the fact that (i) those with labor income are more likely to purchase term-life insurance because one primary function of term-life insurance is to replace labor income in the event of an income earner's death; and (ii) current workers are more likely to be covered by the employer-provided term-life plan. 
Table 6: Loss Aversion, Term-life \& Whole-life Insurance (Age $\geq 60$ )

\begin{tabular}{|c|c|c|c|c|c|c|}
\hline \multicolumn{7}{|c|}{ Whole-Life Insurance } \\
\hline VARIABLES & $\begin{array}{l}\text { (1) Probit } \\
\text { own_term }\end{array}$ & $\begin{array}{l}\text { (2) OLS } \\
\text { num_term }\end{array}$ & $\begin{array}{c}\text { (3) Tobit } \\
\text { log_amt_term }\end{array}$ & $\begin{array}{l}\text { (4) Probit } \\
\text { own_whole }\end{array}$ & $\begin{array}{l}\text { (5) OLS } \\
\text { num_whole }\end{array}$ & $\begin{array}{c}\text { (6) Tobit } \\
\text { log_amt_whole }\end{array}$ \\
\hline Constant & $\begin{array}{c}-0.0984^{*} \\
(0.0568) \\
-0.0814 \\
(0.161)\end{array}$ & $\begin{array}{c}-0.0695^{*} \\
(0.0357) \\
0.674^{* * *} \\
(0.103)\end{array}$ & $\begin{array}{c}-1.685^{* *} \\
(0.664) \\
-0.380 \\
(1.930)\end{array}$ & $\begin{array}{c}0.0974 \\
(0.0606) \\
-0.893^{* * *} \\
(0.173)\end{array}$ & $\begin{array}{l}0.0456^{*} \\
(0.0273) \\
0.223^{* * *} \\
(0.0760)\end{array}$ & $\begin{array}{c}0.919 \\
(1.404) \\
-24.73^{* * *} \\
(4.156)\end{array}$ \\
\hline $\begin{array}{l}\text { Observations } \\
\text { R-squared }\end{array}$ & 1,051 & $\begin{array}{l}1,050 \\
0.004\end{array}$ & 987 & 1,051 & $\begin{array}{l}1,048 \\
0.002\end{array}$ & 862 \\
\hline \multicolumn{7}{|c|}{ Panel B. Regressions with control variables } \\
\hline VARIABLES & $\begin{array}{l}\text { (1) Probit } \\
\text { own_term }\end{array}$ & $\begin{array}{l}\text { (2) OLS } \\
\text { num_term }\end{array}$ & $\begin{array}{c}\text { (3) Tobit } \\
\text { log_amt_term }\end{array}$ & $\begin{array}{l}\text { (4) Probit } \\
\text { own_whole }\end{array}$ & $\begin{array}{c}\text { (5) OLS } \\
\text { num_whole }\end{array}$ & $\begin{array}{c}\text { (6) Tobit } \\
\text { log_amt_whole }\end{array}$ \\
\hline lossavers & $\begin{array}{c}-0.0964^{*} \\
(0.0583)\end{array}$ & $\begin{array}{c}-0.0674^{*} \\
(0.0351)\end{array}$ & $\begin{array}{c}-1.337^{* *} \\
(0.629)\end{array}$ & $\begin{array}{c}0.0984 \\
(0.0619)\end{array}$ & $\begin{array}{c}0.0452 \\
(0.0276)\end{array}$ & $\begin{array}{c}0.834 \\
(1.394)\end{array}$ \\
\hline will & $\begin{array}{c}0.0456 \\
(0.0950)\end{array}$ & $\begin{array}{c}0.0299 \\
(0.0578)\end{array}$ & $\begin{array}{c}0.341 \\
(1.070)\end{array}$ & $\begin{array}{l}0.213^{* *} \\
(0.0992)\end{array}$ & $\begin{array}{l}0.0882^{* *} \\
(0.0447)\end{array}$ & $\begin{array}{l}5.597^{* *} \\
(2.288)\end{array}$ \\
\hline log_income & $\begin{array}{c}0.0179 \\
(0.0369)\end{array}$ & $\begin{array}{c}0.0235 \\
(0.0203)\end{array}$ & $\begin{array}{c}0.113 \\
(0.416)\end{array}$ & $\begin{array}{c}0.0265 \\
(0.0334)\end{array}$ & $\begin{array}{c}0.0193 \\
(0.0131)\end{array}$ & $\begin{array}{c}0.574 \\
(0.830)\end{array}$ \\
\hline log_networth & $\begin{array}{c}0.0379^{* * * *} \\
(0.0134)\end{array}$ & $\begin{array}{l}0.0152^{* *} \\
(0.00621)\end{array}$ & $\begin{array}{l}0.391^{* *} \\
(0.159)\end{array}$ & $\begin{array}{l}0.00712 \\
(0.0131)\end{array}$ & $\begin{array}{c}0.00425 \\
(0.00484)\end{array}$ & $\begin{array}{c}0.301 \\
(0.311)\end{array}$ \\
\hline female & $\begin{array}{c}-0.115 \\
(0.0852)\end{array}$ & $\begin{array}{c}-0.0874^{*} \\
(0.0507)\end{array}$ & $\begin{array}{l}-0.976 \\
(0.971)\end{array}$ & $\begin{array}{l}-0.216^{* *} \\
(0.0874)\end{array}$ & $\begin{array}{c}-0.142^{* * *} \\
(0.0431)\end{array}$ & $\begin{array}{c}-7.232^{* * *} \\
(1.860)\end{array}$ \\
\hline married & $\begin{array}{l}-0.0430 \\
(0.0966)\end{array}$ & $\begin{array}{c}-0.00415 \\
(0.0570)\end{array}$ & $\begin{array}{c}0.147 \\
(1.107)\end{array}$ & $\begin{array}{c}0.00991 \\
(0.100)\end{array}$ & $\begin{array}{l}0.00903 \\
(0.0474)\end{array}$ & $\begin{array}{c}-0.0943 \\
(2.253)\end{array}$ \\
\hline age & $\begin{array}{l}-0.0568 \\
(0.0764)\end{array}$ & $\begin{array}{l}-0.0243 \\
(0.0412)\end{array}$ & $\begin{array}{l}-0.707 \\
(0.888)\end{array}$ & $\begin{array}{c}0.146^{*} \\
(0.0875)\end{array}$ & $\begin{array}{c}0.0567 \\
(0.0386)\end{array}$ & $\begin{array}{c}3.351 \\
(2.169)\end{array}$ \\
\hline age_sq & $\begin{array}{c}0.000300 \\
(0.000513)\end{array}$ & $\begin{array}{c}0.000125 \\
(0.000272)\end{array}$ & $\begin{array}{c}0.00323 \\
(0.00600)\end{array}$ & $\begin{array}{l}-0.00101^{*} \\
(0.000590)\end{array}$ & $\begin{array}{l}-0.000380 \\
(0.000259)\end{array}$ & $\begin{array}{l}-0.0234 \\
(0.0147)\end{array}$ \\
\hline edu & $\begin{array}{c}0.0441^{* * *} \\
(0.0144)\end{array}$ & $\begin{array}{c}0.0122^{*} \\
(0.00705)\end{array}$ & $\begin{array}{c}0.554^{* * *} \\
(0.167)\end{array}$ & $\begin{array}{l}0.00750 \\
(0.0153)\end{array}$ & $\begin{array}{c}0.00319 \\
(0.00709)\end{array}$ & $\begin{array}{c}0.143 \\
(0.369)\end{array}$ \\
\hline kids & $\begin{array}{l}0.00284 \\
(0.0199)\end{array}$ & $\begin{array}{c}-0.00962 \\
(0.0102)\end{array}$ & $\begin{array}{l}0.0388 \\
(0.227)\end{array}$ & $\begin{array}{c}0.0246 \\
(0.0205)\end{array}$ & $\begin{array}{c}0.00426 \\
(0.00929)\end{array}$ & $\begin{array}{c}0.00502 \\
(0.437)\end{array}$ \\
\hline employed & $\begin{array}{l}0.218^{* *} \\
(0.108)\end{array}$ & $\begin{array}{l}0.145^{* *} \\
(0.0666)\end{array}$ & $\begin{array}{l}2.698^{* *} \\
(1.173)\end{array}$ & $\begin{array}{c}0.113 \\
(0.115)\end{array}$ & $\begin{array}{c}0.0277 \\
(0.0514)\end{array}$ & $\begin{array}{c}3.602 \\
(2.452)\end{array}$ \\
\hline Constant & $\begin{array}{c}1.269 \\
(2.852)\end{array}$ & $\begin{array}{c}1.243 \\
(1.547)\end{array}$ & $\begin{array}{c}20.00 \\
(33.09)\end{array}$ & $\begin{array}{c}-6.649^{* *} \\
(3.240)\end{array}$ & $\begin{array}{l}-2.136 \\
(1.410)\end{array}$ & $\begin{array}{c}-153.6^{*} \\
(78.68)\end{array}$ \\
\hline $\begin{array}{l}\text { Observations } \\
\text { R-squared }\end{array}$ & 1,042 & $\begin{array}{l}1,041 \\
0.047\end{array}$ & 978 & 1,042 & $\begin{array}{l}1,039 \\
0.029 \\
\end{array}$ & 854 \\
\hline
\end{tabular}

Notes: Robust standard errors in parentheses. ${ }^{* *} p<0.01$, ** $p<0.05, * p<0.1$.

Dependent variables are individual-level indicator variables for owning term-life or whole-life insurance (column $1 \& 4$ respectively), the number of term-life or whole-life plans (column $2 \& 5$ respectively), and the natural log of 'face value of term-life or whole-life insurance +1 ' (column 3 \& 6 respectively). Lossavers is a continuous variable for loss aversion (1.015, $1.05, \cdots, 3.15)$. Will is an indicator variable for having a written will. Log_networth is the natural log of 'the total net wealth including secondary residence (H11WTOTB) +1 ' (The value in the log is replaced with one if the original value is less than one). Edu is years of education. Kids is the number of children. Employed is an indicator variable for the person is currently working. 
Table 7: Choices between Term-life \& Whole-life Insurance Conditional On Holding Any Life Insurance (Age $\geq 60$ )

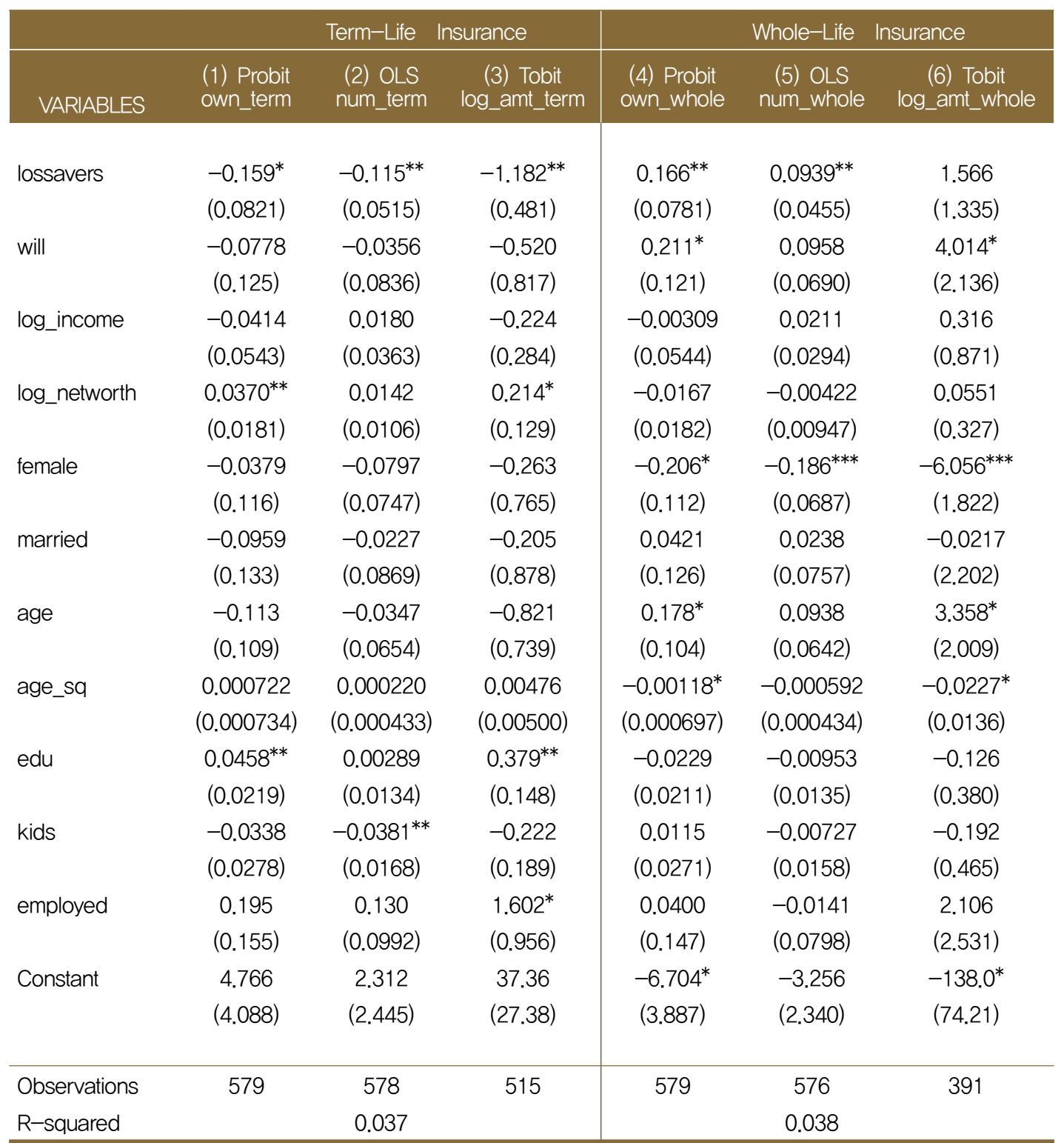

Notes: Robust standard errors in parentheses. ${ }^{* *} \mathrm{p}<0.01,{ }^{* *} \mathrm{p}<0.05,{ }^{*} \mathrm{p}<0.1$.

Dependent variables are an individual-level indicator variable for owning term-life insurance (column 1) and whole-life insurance (column 4), the number of term-life or whole-life plans (column 2 \& 5 respectively), and the natural log of 'face value of term-life or whole-life insurance $+1^{\prime}$ (column $3 \& 6$ respectively). Lossavers is a continuous variable for loss aversion $(1.015,1.05, \cdots, 3.15)$. Will is an indicator variable for having a written will. Log_networth is the natural log of 'the total net wealth including secondary residence (H11WTOTB) +1 ' (The value in the log is replaced with one if the original value is less than one). Edu is years of education. kids is the number of children. Employed is an indicator variable for whether the person is currently working. See Table A.1 (Appendix) for details of variables. 


\section{Interaction with the expected survival probability}

This paper now addresses the prediction [A5]: if the effect of loss aversion on insurance demand is amplified by the degree of narrow framing and the expected survival probability. First, it examines if the negative effect of loss aversion is more prominent among those who expect that they will not die in the near future (those who expect that they are more likely to lose premiums if they purchase term-limited insurance). To measure the expected survival probability, the HRS question is used, which asks the percent chance that a respondent will live at least $11 \sim 15$ more years (prob_live80100). A dummy variable, livesure, indicates that the respondent responds $90 \sim 100$ percent to the question. Column (3) of Table 8 reports a significant negative coefficient of the interaction term (lossavers $\times$ livesure) in the regressions for own_term and $\log$ amt_term, indicating that the effect of loss aversion is indeed large among those who expect that they will live 11 15 more years with the probability of 90 percent or more. Columns (2) of Table 8, however, show that the interaction term is not significant in the regression for num_term. Another result to note is that the expected survival probability itself (prob_live80100) shows a positive sign, not a negative sign, as the model has predicted, although all coefficients are not statistically significant. Overall, while some of the results are in line with the model's prediction, there are somewhat weaker results in terms of loss aversion's interaction with the expected survival probability. 
Table 8: Interaction between Loss Aversion and the Expected Survival Probability (Age $\geq 60)$

\begin{tabular}{|c|c|c|c|c|c|c|}
\hline \multirow[b]{2}{*}{ VARIABLES } & \multicolumn{3}{|c|}{ Term-Life Insurance } & \multicolumn{3}{|c|}{ Whole-Life Insurance } \\
\hline & $\begin{array}{l}\text { (1) Probit } \\
\text { own_term }\end{array}$ & $\begin{array}{l}\text { (2) OLS } \\
\text { num_term }\end{array}$ & $\begin{array}{c}\text { (3) Tobit } \\
\text { log_amt_term }\end{array}$ & $\begin{array}{l}\text { (4) Probit } \\
\text { own_whole }\end{array}$ & $\begin{array}{l}\text { (5) OLS } \\
\text { num_whole }\end{array}$ & $\begin{array}{c}\text { (6) Tobit } \\
\text { log_amt_whole }\end{array}$ \\
\hline lossavers & $\begin{array}{l}-0.0843 \\
(0.0605)\end{array}$ & $\begin{array}{c}-0.0621^{*} \\
(0.0370)\end{array}$ & $\begin{array}{c}-1.144^{*} \\
(0.642)\end{array}$ & $\begin{array}{c}0.108^{*} \\
(0.0646)\end{array}$ & $\begin{array}{c}0.0467 \\
(0.0292)\end{array}$ & $\begin{array}{c}0.893 \\
(1.415)\end{array}$ \\
\hline lossavers $\mathrm{x}$ livesure & $\begin{array}{c}-0.0590^{*} \\
(0.0359)\end{array}$ & $\begin{array}{l}-0.0193 \\
(0.0184)\end{array}$ & $\begin{array}{c}-0.912^{* *} \\
(0.433)\end{array}$ & $\begin{array}{c}-0.00700 \\
(0.0371)\end{array}$ & $\begin{array}{l}0.00199 \\
(0.0200)\end{array}$ & $\begin{array}{l}-0.609 \\
(0.839)\end{array}$ \\
\hline prob_live80100 & $\begin{array}{c}0.00219 \\
(0.00171)\end{array}$ & $\begin{array}{l}9.84 e-05 \\
(0.00103)\end{array}$ & $\begin{array}{c}0.0309 \\
(0.0191)\end{array}$ & $\begin{array}{l}0.000772 \\
(0.00177)\end{array}$ & $\begin{array}{c}0.000489 \\
(0.000829)\end{array}$ & $\begin{array}{c}0.0422 \\
(0.0380)\end{array}$ \\
\hline will & $\begin{array}{c}0.0474 \\
(0.0981)\end{array}$ & $\begin{array}{c}0.0393 \\
(0.0598)\end{array}$ & $\begin{array}{c}-0.0719 \\
(1.091)\end{array}$ & $\begin{array}{l}0.185^{*} \\
(0.102)\end{array}$ & $\begin{array}{l}0.0796 * \\
(0.0470)\end{array}$ & $\begin{array}{l}5.531^{* *} \\
(2.303)\end{array}$ \\
\hline log_income & $\begin{array}{c}-0.00395 \\
(0.0381)\end{array}$ & $\begin{array}{c}0.0166 \\
(0.0221)\end{array}$ & $\begin{array}{r}-0.0957 \\
(0.415)\end{array}$ & $\begin{array}{c}0.0328 \\
(0.0358)\end{array}$ & $\begin{array}{c}0.0214 \\
(0.0144)\end{array}$ & $\begin{array}{c}0.389 \\
(0.795)\end{array}$ \\
\hline log_networth & $\begin{array}{c}0.0387^{* * *} \\
(0.0138)\end{array}$ & $\begin{array}{l}0.0154^{* *} \\
(0.00658)\end{array}$ & $\begin{array}{l}0.384^{* *} \\
(0.161)\end{array}$ & $\begin{array}{l}0.00847 \\
(0.0136)\end{array}$ & $\begin{array}{c}0.00500 \\
(0.00510)\end{array}$ & $\begin{array}{c}0.324 \\
(0.314)\end{array}$ \\
\hline female & $\begin{array}{c}-0.107 \\
(0.0888)\end{array}$ & $\begin{array}{l}-0.0859 \\
(0.0534)\end{array}$ & $\begin{array}{l}-0.849 \\
(1.005)\end{array}$ & $\begin{array}{c}-0.230 * * \\
(0.0904)\end{array}$ & $\begin{array}{c}-0.148^{* * *} \\
(0.0451)\end{array}$ & $\begin{array}{c}-7.485^{* * *} \\
(1.867)\end{array}$ \\
\hline married & $\begin{array}{c}-0.0246 \\
(0.100)\end{array}$ & $\begin{array}{l}-0.0100 \\
(0.0594)\end{array}$ & $\begin{array}{c}0.308 \\
(1.134)\end{array}$ & $\begin{array}{l}0.0108 \\
(0.104)\end{array}$ & $\begin{array}{l}0.00613 \\
(0.0499)\end{array}$ & $\begin{array}{l}-0.296 \\
(2.266)\end{array}$ \\
\hline age & $\begin{array}{c}-0.0765 \\
(0.109)\end{array}$ & $\begin{array}{l}-0.0383 \\
(0.0620)\end{array}$ & $\begin{array}{l}-1.386 \\
(1.238)\end{array}$ & $\begin{array}{l}0.264^{* *} \\
(0.116)\end{array}$ & $\begin{array}{c}0.0826 \\
(0.0572)\end{array}$ & $\begin{array}{c}3.719 \\
(2.712)\end{array}$ \\
\hline age_sq & $\begin{array}{c}0.000446 \\
(0.000750)\end{array}$ & $\begin{array}{c}0.000224 \\
(0.000423)\end{array}$ & $\begin{array}{c}0.00816 \\
(0.00858)\end{array}$ & $\begin{array}{c}-0.00183^{* *} \\
(0.000801)\end{array}$ & $\begin{array}{r}-0.000559 \\
(0.000395)\end{array}$ & $\begin{array}{l}-0.0261 \\
(0.0187)\end{array}$ \\
\hline edu & $\begin{array}{c}0.0431^{* * *} \\
(0.0150)\end{array}$ & $\begin{array}{c}0.0126^{*} \\
(0.00753)\end{array}$ & $\begin{array}{c}0.537^{* * *} \\
(0.170)\end{array}$ & $\begin{array}{l}0.00444 \\
(0.0161)\end{array}$ & $\begin{array}{c}0.00153 \\
(0.00768)\end{array}$ & $\begin{array}{l}0.0915 \\
(0.376)\end{array}$ \\
\hline kids & $\begin{array}{l}0.00908 \\
(0.0207)\end{array}$ & $\begin{array}{c}-0.00569 \\
(0.0108)\end{array}$ & $\begin{array}{l}0.0646 \\
(0.231)\end{array}$ & $\begin{array}{c}0.0185 \\
(0.0212)\end{array}$ & $\begin{array}{l}0.000528 \\
(0.00978)\end{array}$ & $\begin{array}{c}-0.0685 \\
(0.446)\end{array}$ \\
\hline employed & $\begin{array}{l}0.252^{* *} \\
(0.111)\end{array}$ & $\begin{array}{l}0.166^{* *} \\
(0.0691)\end{array}$ & $\begin{array}{l}2.940^{* *} \\
(1.192)\end{array}$ & $\begin{array}{c}0.103 \\
(0.117)\end{array}$ & $\begin{array}{c}0.0214 \\
(0.0535)\end{array}$ & $\begin{array}{c}3.517 \\
(2.449)\end{array}$ \\
\hline Constant & $\begin{array}{c}2.015 \\
(3.940)\end{array}$ & $\begin{array}{c}1.766 \\
(2.244)\end{array}$ & $\begin{array}{c}44.12 \\
(44.59)\end{array}$ & $\begin{array}{c}-10.88^{* * *} \\
(4.213)\end{array}$ & $\begin{array}{l}-3.074 \\
(2.029)\end{array}$ & $\begin{array}{c}-164.5^{*} \\
(96.90)\end{array}$ \\
\hline $\begin{array}{l}\text { Observations } \\
\text { R-squared }\end{array}$ & 968 & $\begin{array}{c}967 \\
0.046\end{array}$ & 911 & 968 & $\begin{array}{c}965 \\
0.030\end{array}$ & 791 \\
\hline
\end{tabular}

Notes: Robust standard errors in parentheses. $* * * p<0.01$, ** $p<0.05$, ${ }^{*} p<0.1$. prob_live80100 is the respondents' subjective expectation on the percent chance that he/she will live at least 11 15 more years. It is based on the question "What is the percent chance that you will

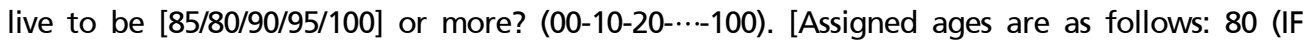
AGE IS 65-69) 85 (IF AGE IS 70-74) 90 (IF AGE IS 75-79) 95 (IF AGE IS 80-84) 100 (IF AGE IS 85-89)]. Livesure is an indicator variable for prob_live80100 being $90-100$ percent. See Table A1 (Appendix) for details of variables. 


\section{Interaction with the degree of narrow framing (proxied by the inverse of taking financial advice)}

Kahneman (2003) points out that narrow framing is associated with the "low accessibility" to a person's existing risk and portfolio. This paper posits that those who have taken financial advice from financial experts are more likely to have realized his/her existing risk and thus are more likely to have broad framing rather than narrow framing. Financial advice may also have direct impact on life insurance take-up because financial experts may encourage individuals to purchase a life insurance plan. To capture these effects, the HRS 2014 module question regarding financial advice is used. The variable, advice, is an indicator variable for whether a person takes financial advice from experts (e.g., bank officer, financial consultant). When the 'advice' variable is merged with the loss aversion data, there are fewer than one hundred samples. Although the sample size is less than ideal, interesting patterns that are consistent with the model are found in the regression results. First, the sign of the interaction term (i_lossaver $\times$ advice) is positive in columns (1)-(3) and negative in columns (4)-(6), which is consistent with the prediction of the model. The results imply that the effect of loss aversion on insurance uptake is canceled out by financial advice. However, only three interaction terms are statistically significant. Direct effects of financial advice on term-life and whole-life ownership (apart from the interaction effect with loss aversion) are captured by the 'advice' term, but all of them are insignificant. 
Table 9: Interaction between Loss Aversion and Narrow Framing (Proxied by the Inverse of Taking Financial Advice, Age $\geq 60$ )

\begin{tabular}{|c|c|c|c|c|c|c|}
\hline & \multicolumn{3}{|c|}{ Term-Life Insurance } & \multicolumn{3}{|c|}{ Whole-Life Insurance } \\
\hline VARIABLES & $\begin{array}{l}\text { (1) Probit } \\
\text { own_term }\end{array}$ & $\begin{array}{l}\text { (2) OLS } \\
\text { num_term }\end{array}$ & $\begin{array}{c}\text { (3) Tobit } \\
\text { log_amt_term }\end{array}$ & $\begin{array}{l}\text { (4) Probit } \\
\text { own_whole }\end{array}$ & $\begin{array}{l}\text { (5) OLS } \\
\text { num_whole }\end{array}$ & $\begin{array}{c}\text { (6) Tobit } \\
\text { log_amt_whole }\end{array}$ \\
\hline lossavers & $\begin{array}{c}-0.455^{*} \\
(0.233)\end{array}$ & $\begin{array}{c}-0.214^{*} \\
(0.108)\end{array}$ & $\begin{array}{c}-4.504^{* *} \\
(1.953)\end{array}$ & $\begin{array}{l}0.523^{* *} \\
(0.237)\end{array}$ & $\begin{array}{l}0.190^{* *} \\
(0.0756)\end{array}$ & $\begin{array}{c}71.74^{* * *} \\
(0.732)\end{array}$ \\
\hline i_lossaver_advice & $\begin{array}{c}0.915 \\
(0.914)\end{array}$ & $\begin{array}{l}0.555^{*} \\
(0.324)\end{array}$ & $\begin{array}{c}10.38 \\
(8.228)\end{array}$ & $\begin{array}{c}-2.294^{* *} \\
(1.065)\end{array}$ & $\begin{array}{c}-0.627^{*} \\
(0.360)\end{array}$ & $\begin{array}{c}-161.0 \\
(0)\end{array}$ \\
\hline advice & $\begin{array}{c}-0.536 \\
(0.759)\end{array}$ & $\begin{array}{l}-0.374 \\
(0.240)\end{array}$ & $\begin{array}{l}-4.574 \\
(6.620)\end{array}$ & $\begin{array}{c}1.314 \\
(0.846)\end{array}$ & $\begin{array}{c}0.395 \\
(0.246)\end{array}$ & $\begin{array}{c}81.36 \\
(0)\end{array}$ \\
\hline will & $\begin{array}{c}-0.709^{*} \\
(0.416)\end{array}$ & $\begin{array}{l}-0.251 \\
(0.160)\end{array}$ & $\begin{array}{l}-5.375 \\
(4.016)\end{array}$ & $\begin{array}{l}0.764^{*} \\
(0.396)\end{array}$ & $\begin{array}{c}0.250 \\
(0.156)\end{array}$ & $\begin{array}{c}21.96^{* * *} \\
(2.001)\end{array}$ \\
\hline log_income & $\begin{array}{c}0.281 \\
(0.257)\end{array}$ & $\begin{array}{c}0.143 \\
(0.116)\end{array}$ & $\begin{array}{c}3.829 \\
(2.452)\end{array}$ & $\begin{array}{l}0.0583 \\
(0.248)\end{array}$ & $\begin{array}{l}0.0582 \\
(0.119)\end{array}$ & $\begin{array}{c}6.659^{* * *} \\
(0.216)\end{array}$ \\
\hline log_networth & $\begin{array}{c}0.0189 \\
(0.0473)\end{array}$ & $\begin{array}{l}0.00472 \\
(0.0170)\end{array}$ & $\begin{array}{c}0.161 \\
(0.475)\end{array}$ & $\begin{array}{l}0.0847^{*} \\
(0.0446)\end{array}$ & $\begin{array}{c}0.0174 \\
(0.0144)\end{array}$ & $\begin{array}{l}0.0112 \\
(0.182)\end{array}$ \\
\hline female & $\begin{array}{c}0.221 \\
(0.333)\end{array}$ & $\begin{array}{l}0.0452 \\
(0.119)\end{array}$ & $\begin{array}{c}1.774 \\
(3.446)\end{array}$ & $\begin{array}{l}-0.442 \\
(0.344)\end{array}$ & $\begin{array}{l}-0.165 \\
(0.161)\end{array}$ & $\begin{array}{l}-2.281 \\
(1.756)\end{array}$ \\
\hline married & $\begin{array}{l}-0.443 \\
(0.422)\end{array}$ & $\begin{array}{l}-0.171 \\
(0.159)\end{array}$ & $\begin{array}{l}-4.746 \\
(4.329)\end{array}$ & $\begin{array}{l}-0.200 \\
(0.435)\end{array}$ & $\begin{array}{c}-0.0352 \\
(0.191)\end{array}$ & $\begin{array}{c}2.996 \\
(1.968)\end{array}$ \\
\hline age & $\begin{array}{l}-0.0245 \\
(0.0256)\end{array}$ & $\begin{array}{r}-0.00482 \\
(0.00867)\end{array}$ & $\begin{array}{l}-0.392 \\
(0.282)\end{array}$ & $\begin{array}{c}-0.00556 \\
(0.0213)\end{array}$ & $\begin{array}{l}-0.00341 \\
(0.00905)\end{array}$ & $\begin{array}{c}-0.897^{* * *} \\
(0.0322)\end{array}$ \\
\hline edu & $\begin{array}{c}0.0618 \\
(0.0647)\end{array}$ & $\begin{array}{c}0.0193 \\
(0.0199)\end{array}$ & $\begin{array}{c}0.188 \\
(0.570)\end{array}$ & $\begin{array}{l}-0.0721 \\
(0.0552)\end{array}$ & $\begin{array}{l}-0.0232 \\
(0.0290)\end{array}$ & $\begin{array}{c}-2.020^{* * *} \\
(0.165)\end{array}$ \\
\hline kids & $\begin{array}{c}0.0580 \\
(0.0794)\end{array}$ & $\begin{array}{c}0.0166 \\
(0.0326)\end{array}$ & $\begin{array}{c}0.859 \\
(0.778)\end{array}$ & $\begin{array}{c}0.154^{*} \\
(0.0858)\end{array}$ & $\begin{array}{c}0.0542 \\
(0.0391)\end{array}$ & $\begin{array}{c}2.665^{* * *} \\
(0.366)\end{array}$ \\
\hline employed & $\begin{array}{c}0.151 \\
(0.437)\end{array}$ & $\begin{array}{c}0.162 \\
(0.200)\end{array}$ & $\begin{array}{c}0.658 \\
(4.366)\end{array}$ & $\begin{array}{c}0.295 \\
(0.465)\end{array}$ & $\begin{array}{c}-0.0150 \\
(0.183)\end{array}$ & $\begin{array}{c}-6.983^{* * *} \\
(1.422)\end{array}$ \\
\hline Constant & $\begin{array}{l}-1.165 \\
(3.423)\end{array}$ & $\begin{array}{l}-0.372 \\
(1.319)\end{array}$ & $\begin{array}{l}-7.535 \\
(36.30)\end{array}$ & $\begin{array}{l}-3.072 \\
(3.003)\end{array}$ & $\begin{array}{l}-0.649 \\
(1.507)\end{array}$ & $\begin{array}{c}-241.8^{* * *} \\
(2.307)\end{array}$ \\
\hline $\begin{array}{l}\text { Observations } \\
\text { R-squared }\end{array}$ & 92 & $\begin{array}{c}92 \\
0.246\end{array}$ & 90 & 91 & $\begin{array}{c}91 \\
0.110\end{array}$ & 73 \\
\hline
\end{tabular}

Notes: Robust standard errors in parentheses. $* * * p<0.01, * * p<0.05, * p<0.1$.

Advice is an indicator variable for getting advice from financial experts. It is based on the 2014 HRS Module questions "Do you [and your[partner/husband/wife]] have someone such as a friend or relative, or bank officer, lawyer or financial consultant who regularly helps you with handling your money or property or other financial matters such as signing checks, paying bills, dealing with banks and making investments? [Yes /No]" and "[IF YES] Who helps you [and your [partner/husband/wife]] with your finances? 1. Child Or Child-In-Law, 2. Other Relative, 3. Friend, 4. Lawyer, 5. Bank Officer, 6. Financial Consultant, Accountant Or Other Professional Investment Counselor, 7. Other, Specify." The value of zero is assigned if a respondent chooses "No" to the first question or "1 4, or 7" to the second question. The value of one is assigned if a respondent choose Yes in the first question and ( 5 or 6 ) in the second question (getting help from financial experts). 


\section{Robustness checks}

First, the possible effect of employer-provided term-life insurance is further controlled for. The dependent variable of columns (1)-(2) in Panel A of Table A.7 (Appendix) is an indicator variable for owning two or more policies of term-life insurance. The dependent variable of columns (3)-(4) is the log of the "coverage amount of term-life insurance - $\$ 50,000 "$ (the dependent variable is replaced with 0 if the coverage amount is less than $\$ 50,001$ ). By using these dependent variables, we consider the possibility that one term-life insurance plan with the coverage amount of $\$ 50,000$ or less can be provided by employers. The results in columns (1)-(3) of Panel A show that the negative effect of loss aversion on term-life insurance is significant even if the possibility that the first term-life insurance policy is provided by employers is considered. In the case of column (4), loss aversion is only marginally significant (p-value: 13.2 percent). However, in this case also, loss aversion maintains its negative sign. In Panel B of Table A.7 (Appendix), regression results are reported when 13 occupation dummy variables based on industry codes with the longest reported tenure are added. There are still significant coefficients of loss aversion in the regressions for term-life insurance.

Second, the sample is restricted to low-wealth individuals to consider the possibility that (i) the level of wealth may affect individuals' attitude toward loss and (ii) to control for the heterogeneous tax-exemption or tax-deference effects of life insurance that differs by wealth levels (Brown 2001). In particular, the possibility that wealth levels co-determine loss aversion (in the form of decreasing absolute risk aversion (DARA) or increasing absolute risk aversion (IARA)) and life insurance ownership decisions can be ruled out by looking at similar wealth-level individuals. This study chooses low-wealth individuals who are less likely to be affected by tax incentives of whole-life insurance. The results in Table A.8 (Appendix) show that statistical significance is somewhat weakened from the baseline results as the sample size has halved. Still, loss aversion is significant at 5 percent in the regression for num_term and at 10 percent in the regression for log_amt_term.

Third, a risk-aversion measure is added to address a possible omitted 
variable problem. The status-quo-bias-free lifetime income gamble questions by Barsky et al. (1997) are used to measure risk-aversion. Note that the lifetime income gamble questions capture the concavity of Bernoulli's utility-of-wealth function, which represents risk attitude when the magnitude of risk is large and when all risks are assessed comprehensively within a broad frame. This contrasts with the loss-aversion questions capturing the concavity of Kahneman and Tversky's $(1979,1992)$ value function when the magnitude of risk is small and when each risk is likely to be assessed in isolation from each other. (See Table 1 and Figure 3). The number of observations in which both risk-aversion and loss-aversion measures are available is about 360. Panel A in Table A.9 (Appendix) reports that loss aversion maintains its significant negative sign in the regressions for term-life insurance holdings and shows a positive sign in the regressions for whole-life holdings. One thing to note is that the risk-aversion measure shows a significant negative sign in the regression for whole-life insurance. To further examine the relationship between risk aversion and life insurance holdings, the loss-aversion measure is dropped from explanatory variables so that the relationship can be tested in a large sample. When loss aversion is dropped from the covariates, available observations increase to about 4,000 individuals. In this large data set, risk aversion is found to be an insignificant variable in the regressions for whole-life insurance (See Panel B of Table A.9 (Appendix)). This relationship between risk aversion and life insurance holdings is further explained using an age cohort sample.

Fourth, the sample is restricted to those in the same life-cycle stage, those aged 60-69 in particular. Table A.10 (Appendix) reports the results. These results are similar to the previous results: loss aversion is significantly negatively associated with term-life insurance and is positively associated with whole-life insurance. Note that even if the risk aversion measure is added to this age cohort sample, loss aversion's effects remain robust while risk-aversion is not significant (Panel B of Table A.10, Appendix). Another pattern to note is that, although statistically insignificant, risk aversion tends to be positively associated with term-life insurance ownership and negatively associated whole-life insurance ownership. This pattern is consistent with the rational aspects of 
purchasing insurance.

Fifth, the Bivariate Probit, SUR, and Bivariate Tobit models are employed to consider the cases where decisions to buy term-life and whole-life are jointly determined.14) Since term-life and whole-life insurance are partial substitutes of each other, owning one type of life insurance may have a negative effect on the purchase of the other type of life insurance. Results for Bivariate Probit model for two binary outcomes (own_term, own_whole) are reported in columns (1)-(2) in Table A.11 (Appendix). Although the estimated coefficients of loss-aversion are similar to the baseline results in Table 6 (two separate Probit models), the correlation $(\rho)$ between term-life and whole-life ownership is estimated to be -0.232 and significant at $1 \%$. This indicates that the two types of life insurance are indeed partial substitutes of each other. This negative correlation is in line with previous literature, such as Frees and Sun (2010). Columns (3)-(4) report SUR estimation results for the number of plans, which can be more efficient than two separate OLS regressions. Columns (5)-(6) report estimation results of the Bivariate Tobit model for the coverage amount. The results are not significantly different from those in Table 6.

Sixth, an indicator variable is used for high loss-aversion rather than using a continuous measure for loss aversion. The indicator variable (i_lossaver) takes the value of one if a person's loss aversion is greater than three and zero otherwise. Table A.12 (Appendix) reports similar results to those in Table 6 .

Lastly, another control variable, self-reported health status is added to control for the possible adverse selection problem in the life insurance market. One can verify that the results in Table A.13 (Appendix) are similar to the baseline results.

\subsubsection{Regression Results 2: Loss Aversion and Household Wealth}

This section examines if loss aversion increases savings (Prediction [A2]) by looking at loss-aversion's association with households' wealth levels. Since the logged wealth variables are left-censored at zero, the Tobit model is employed.

14) For estimation, Stata codes 'biprobit', 'sureg', and 'mvtobit' are used. 
Analyzed samples are restricted to those aged 65 or more so that the focus is on those who have entered the retirement stage and hence finished their wealth accumulation processes. Columns (1) and (6) in Table 10 report that loss aversion is negatively associated with $\log _{-}$Stock, which represents the sum of the amount of stocks, mutual funds, and investment trusts a household holds. This negative association is consistent with the model (loss-averse individuals are less likely to hold risky-looking assets) and the literature on loss-aversion and stock market participation (Dimmock \& Kouwenberg, 2010). Columns (3) and (8) report that loss aversion is positively associated with log_Nonrisky, the amount of non-risky assets as measured by the sum of the 'value of checking, savings, or money market accounts,' 'value of CD, government savings bonds, and T-bills,' and the 'net value of bonds and bond funds.' Columns (5) and (10) show that loss aversion is positively associated with Net Worth, the sum of household's net financial asset and real estate asset, including secondary residences. These results are in line with the prediction [A2].

Another result to note is that having a written will is significantly positively associated with levels of wealth. (columns (6)-(10) in Table 10). Although our estimation strategy does not resolve the possible reverse causality issue (i.e., wealthy individuals are more likely to write a will), the strong positive correlation is in line with the model's prediction [A4]. 
Table 10: Loss Aversion and Household Wealth (Tobit Model, Age $\geq 65$ )

\begin{tabular}{|c|c|c|c|c|c|c|c|c|c|c|}
\hline VARIABLES & $\begin{array}{c}(1) \\
\text { log_Stock }\end{array}$ & $\begin{array}{c}(2) \\
\log _{-} \text {House }\end{array}$ & $\begin{array}{l}\text { (3) log_ } \\
\text { Nonrisky }\end{array}$ & $\begin{array}{l}\text { (4) } \log _{\text {NetFinWorth }}\end{array}$ & $\begin{array}{l}\text { (5) } \log _{-} \\
\text {NetWorth }\end{array}$ & $\begin{array}{c}(6) \\
\log _{\text {SStock }}\end{array}$ & $\begin{array}{l}\text { (7) log_ } \\
\text { House }\end{array}$ & $\begin{array}{l}\text { (8) log_ } \\
\text { Nonrisky }\end{array}$ & $\begin{array}{l}\text { (9) } \log _{\text {NetFinWorth }}\end{array}$ & $\begin{array}{l}\text { (10) log } \\
\text { NetWorth }\end{array}$ \\
\hline lossavers & $\begin{array}{c}-1.560^{*} \\
(0.871)\end{array}$ & $\begin{array}{c}0.378 \\
(0.321)\end{array}$ & $\begin{array}{l}0.571^{* *} \\
(0.250)\end{array}$ & $\begin{array}{c}0.501 \\
(0.315)\end{array}$ & $\begin{array}{l}0.489^{* *} \\
(0.228)\end{array}$ & $\begin{array}{c}-1.964^{* *} \\
(0.839)\end{array}$ & $\begin{array}{c}0.300 \\
(0.295)\end{array}$ & $\begin{array}{l}0.443^{*} \\
(0.228)\end{array}$ & $\begin{array}{c}0.256 \\
(0.291)\end{array}$ & $\begin{array}{l}0.333^{* *} \\
(0.166)\end{array}$ \\
\hline log_income & $\begin{array}{c}5.978^{* * *} \\
(0.734)\end{array}$ & $\begin{array}{c}0.859^{* * *} \\
(0.288)\end{array}$ & $\begin{array}{c}1.154^{* * *} \\
(0.275)\end{array}$ & $\begin{array}{c}1.695^{* * *} \\
(0.396)\end{array}$ & $\begin{array}{c}0.776^{* * *} \\
(0.206)\end{array}$ & $\begin{array}{c}3.764^{* * *} \\
(0.818)\end{array}$ & $\begin{array}{c}0.310 \\
(0.214)\end{array}$ & $\begin{array}{c}0.802^{* * *} \\
(0.232)\end{array}$ & $\begin{array}{c}1.033^{* * *} \\
(0.306)\end{array}$ & $\begin{array}{l}0.230^{* *} \\
(0.106)\end{array}$ \\
\hline edu & $\begin{array}{c}1.621^{* * *} \\
(0.252)\end{array}$ & $\begin{array}{l}0.296 * * * \\
(0.0819)\end{array}$ & $\begin{array}{l}0.535^{* * *} \\
(0.0658)\end{array}$ & $\begin{array}{l}0.669^{* * *} \\
(0.0880)\end{array}$ & $\begin{array}{l}0.315^{* * *} \\
(0.0532)\end{array}$ & $\begin{array}{c}1.100^{* * *} \\
(0.265)\end{array}$ & $\begin{array}{c}0.156^{*} \\
(0.0845)\end{array}$ & $\begin{array}{l}0.283^{* * *} \\
(0.0662)\end{array}$ & $\begin{array}{l}0.375^{* * *} \\
(0.0861)\end{array}$ & $\begin{array}{l}0.159^{* * *} \\
(0.0410)\end{array}$ \\
\hline age & $\begin{array}{c}0.161^{*} \\
(0.0916)\end{array}$ & $\begin{array}{c}-0.0917^{* * *} \\
(0.0336)\end{array}$ & $\begin{array}{c}0.0661^{* * *} \\
(0.0238)\end{array}$ & $\begin{array}{l}0.128^{* * *} \\
(0.0307)\end{array}$ & $\begin{array}{c}-0.00856 \\
(0.0190)\end{array}$ & $\begin{array}{c}3.036 \\
(1.850)\end{array}$ & $\begin{array}{c}0.562 \\
(0.605)\end{array}$ & $\begin{array}{l}-0.315 \\
(0.445)\end{array}$ & $\begin{array}{c}0.510 \\
(0.541)\end{array}$ & $\begin{array}{l}0.0634 \\
(0.272)\end{array}$ \\
\hline age_sq & & & & & & $\begin{array}{l}-0.0194 \\
(0.0120)\end{array}$ & $\begin{array}{l}-0.00410 \\
(0.00393)\end{array}$ & $\begin{array}{c}0.00232 \\
(0.00286)\end{array}$ & $\begin{array}{l}-0.00265 \\
(0.00346)\end{array}$ & $\begin{array}{r}-0.000321 \\
(0.00173)\end{array}$ \\
\hline will & & & & & & $\begin{array}{c}10.05^{* * *} \\
(1.579)\end{array}$ & $\begin{array}{c}2.273^{* * *} \\
(0.476)\end{array}$ & $\begin{array}{c}2.351^{* * *} \\
(0.360)\end{array}$ & $\begin{array}{c}3.603^{* * *} \\
(0.481)\end{array}$ & $\begin{array}{c}1.859^{* * *} \\
(0.245)\end{array}$ \\
\hline female & & & & & & $\begin{array}{l}2.801^{* *} \\
(1.294)\end{array}$ & $\begin{array}{c}0.437 \\
(0.436)\end{array}$ & $\begin{array}{c}0.442 \\
(0.333)\end{array}$ & $\begin{array}{c}0.630 \\
(0.442)\end{array}$ & $\begin{array}{c}0.186 \\
(0.219)\end{array}$ \\
\hline married & & & & & & $\begin{array}{c}4.569^{* * *} \\
(1.497)\end{array}$ & $\begin{array}{c}3.167^{* * *} \\
(0.486)\end{array}$ & $\begin{array}{l}0.817^{* *} \\
(0.360)\end{array}$ & $\begin{array}{c}1.417^{* * *} \\
(0.488)\end{array}$ & $\begin{array}{c}0.979^{* * *} \\
(0.227)\end{array}$ \\
\hline kids & & & & & & $\begin{array}{c}-0.984^{* * *} \\
(0.331)\end{array}$ & $\begin{array}{c}0.0382 \\
(0.0923)\end{array}$ & $\begin{array}{l}-0.0909 \\
(0.0723)\end{array}$ & $\begin{array}{l}-0.117 \\
(0.0951)\end{array}$ & $\begin{array}{l}0.00492 \\
(0.0488)\end{array}$ \\
\hline employed & & & & & & $\begin{array}{l}-2.153 \\
(2.002)\end{array}$ & $\begin{array}{c}-0.0501 \\
(0.616)\end{array}$ & $\begin{array}{l}-0.428 \\
(0.471)\end{array}$ & $\begin{array}{l}-0.440 \\
(0.657)\end{array}$ & $\begin{array}{c}0.476 \\
(0.314)\end{array}$ \\
\hline i_hispanic & & & & & & $\begin{array}{c}-16.57^{* * *} \\
(5.175)\end{array}$ & $\begin{array}{l}-0.754 \\
(0.935)\end{array}$ & $\begin{array}{c}-2.639^{* * *} \\
(0.811)\end{array}$ & $\begin{array}{c}-2.749^{* * *} \\
(0.979)\end{array}$ & $\begin{array}{l}-0.453 \\
(0.495)\end{array}$ \\
\hline own_house & & & & & & $\begin{array}{c}1.873 \\
(1.945)\end{array}$ & & $\begin{array}{c}1.305^{* * *} \\
(0.445)\end{array}$ & $\begin{array}{c}1.843^{* * *} \\
(0.563)\end{array}$ & $\begin{array}{c}4.539^{* * *} \\
(0.387)\end{array}$ \\
\hline Constant & $\begin{array}{c}-99.45^{* * *} \\
(11.02)\end{array}$ & $\begin{array}{c}1.749 \\
(4.201)\end{array}$ & $\begin{array}{c}-17.75^{* * *} \\
(3.649)\end{array}$ & $\begin{array}{c}-29.93^{* * *} \\
(5.030)\end{array}$ & $\begin{array}{l}-1.512 \\
(2.855)\end{array}$ & $\begin{array}{c}-182.2^{* *} \\
(71.35)\end{array}$ & $\begin{array}{l}-20.69 \\
(23.22)\end{array}$ & $\begin{array}{c}1.535 \\
(17.23)\end{array}$ & $\begin{array}{l}-36.97^{*} \\
(21.05)\end{array}$ & $\begin{array}{l}-2.746 \\
(10.56)\end{array}$ \\
\hline $\begin{array}{l}\text { occupation } \\
\text { dummies }\end{array}$ & - & - & - & - & - & 0 & & 0 & 0 & 0 \\
\hline Observations & 834 & 834 & 834 & 834 & 834 & 829 & 829 & 829 & 829 & 829 \\
\hline
\end{tabular}

Notes: Robust standard errors in parentheses. $* * * p<0.01, * \star p<0.05, * p<0.1$.

Occupation_dummies are 13 dummy variables based on the industry code for job with longest tenure (RAND HRS code: R11JLIND). Own_house is an indicator variable for owning house (H11WOHOUS).

\section{Robustness checks}

First, we apply quantile regressions because asset holdings data can be sensitive to extreme values. Results in Table 11 report median regression results in columns (2)-(5) and a 95 percentile regression result in column (1). ${ }^{15)}$ Similar

15) A 95 percentile quantile regression is applied because only about 11 percent of households participate in the stock market. 
to the results in Table 10, loss aversion has a positive association with $\log$ _NetWorth and log_Nonrisky and a negative association with log_Stock. Figure 5 shows the coefficients of loss-aversion when quantile regressions with various percentiles are applied. It shows that loss aversion's effects on asset holdings differ depending on wealth quantiles. Loss aversion's effects are significant among low-to-moderate wealth households.

Second, the sample is restricted to those in the same life-cycle stage, those aged $65-70$ in particular. The results in Table A.14 show that, although statistical significance has been weakened, loss-aversion's association with log_Stock and log_NetWorth remains similar to the baseline results in Table 10.

Third, the indicator variables are used for high loss aversion (i_lossaver, i_lossaver2) rather than using a continuous variable for loss aversion. The results in Table A.15 (Appendix) show that, although statistical significance varies depending on the types of dummy variables, the overall results are similar to the baseline results in Table 10 .

Fourth, the risk-aversion measure (Barsky et al., 1997) is added to address a possible omitted variable problem. The number of observations in which both risk-aversion and loss-aversion measures are available is only 197. Table A.16 (Appendix) reports that loss aversion has a significant negative sign in the regression for log_stock (Column 1). Loss aversion maintains its positive sign in the regression for log_NetWorth but the coefficient is not statistically significant (Column 5). Another point to note is that, in all columns (1)-(5), the risk aversion measure is not statistically significant. To further check if the insignificance of the risk aversion measure is caused by too few samples, the loss-aversion measure is dropped from explanatory variables so that the relationship between risk aversion and wealth can be tested in a large sample. When loss aversion is dropped from covariates, available observations increase to 2,215 individuals. In this large data set, risk aversion is found to be an insignificant variable in all regressions (Columns 6-10 in Table A.16). These results suggest that the risk aversion measure does not have an additional explanatory power on wealth levels when demographic variables are controlled for. This, in turn, implies that although the main regression results do not 
Table 11: Loss Aversion and Household Wealth (Quantile Regression, Age $\geq 65$ )

\begin{tabular}{lccccc}
\multirow{2}{*}{$\begin{array}{c}\text { VARIABLES } \\
\text { quantile }\end{array}$} & $\begin{array}{c}(1) \\
\text { log_Stock }\end{array}$ & $\begin{array}{c}(2) \\
\text { log_House }\end{array}$ & $\begin{array}{c}(3) \\
\text { log_Nonrisky }\end{array}$ & $\begin{array}{c}(4) \\
\text { log_NetFinWorth }\end{array}$ & $\begin{array}{c}(5) \\
\text { log_NetWorth }\end{array}$ \\
\cline { 2 - 6 } log_income & 0.95 & 0.5 & 0.5 & 0.5 & 0.5 \\
& $-0.506^{* *}$ & $0.163^{*}$ & $0.373^{*}$ & 0.0171 & $0.218^{* *}$ \\
age & $(0.236)$ & $(0.0985)$ & $(0.199)$ & $(0.260)$ & $(0.0929)$ \\
& $1.110^{* * *}$ & $0.426^{* * *}$ & $1.166^{* * *}$ & $1.328^{* * *}$ & $0.838^{* * *}$ \\
edu & $(0.137)$ & $(0.0570)$ & $(0.115)$ & $(0.151)$ & $(0.0538)$ \\
& 0.0367 & -0.0100 & $0.0699^{* * *}$ & $0.0866^{* * *}$ & -0.00423 \\
Constant & $(0.0230)$ & $(0.00958)$ & $(0.0194)$ & $(0.0253)$ & $(0.00904)$ \\
& $0.466^{* * *}$ & $0.110^{* * *}$ & $0.422^{* * *}$ & $0.555^{* * *}$ & $0.178^{* * *}$ \\
& $(0.0549)$ & $(0.0229)$ & $(0.0462)$ & $(0.0605)$ & $(0.0216)$ \\
& $-6.635^{* * *}$ & $5.824^{* * *}$ & $-15.05^{* * *}$ & $-18.31^{* * *}$ & 0.953 \\
Observations & $(2.440)$ & $(1.017)$ & $(2.055)$ & $(2.689)$ & $(0.960)$ \\
\hline
\end{tabular}

Notes: Standard errors in parentheses. ${ }^{* * *} p<0.01,{ }^{* *} p<0.05,{ }^{*} p<0.1$.

include the risk aversion measure, the results may not have an omitted variable problem caused by the exclusion of the risk aversion measure. ${ }^{16)}$

Lastly, share by asset type (or asset-specific share) of net worth is used as a dependent variable. Table A.17 reports the Tobit regression results. It shows that, consistent with the prediction of this paper, the Stock's share is significantly negatively associated with loss aversion while Nonrisky's share is positively associated with loss aversion. But in the case of Nonrisky's share, statistical significance is lacking.

16) Note that most empirical studies on insurance purchasing behavior have used demographic variables (e.g., age, gender, family structure) as a proxy for risk aversion instead of using direct measures for risk aversion due to the difficulty of obtaining an appropriate risk aversion measure (Outreville, 2014, p. 170). Recent studies by Hwang (2016a) and Gottlieb and Mitchell (2015) report that the CRRA measure is not a statistically significant determinant of take-up of long-term care insurance or private health insurance. 
Figure 5: Coefficients of Loss Aversion by Quantiles when Quantile Regressions are Estimated at All Percentiles (Specification: Columns (2)-(5) of Table 11)
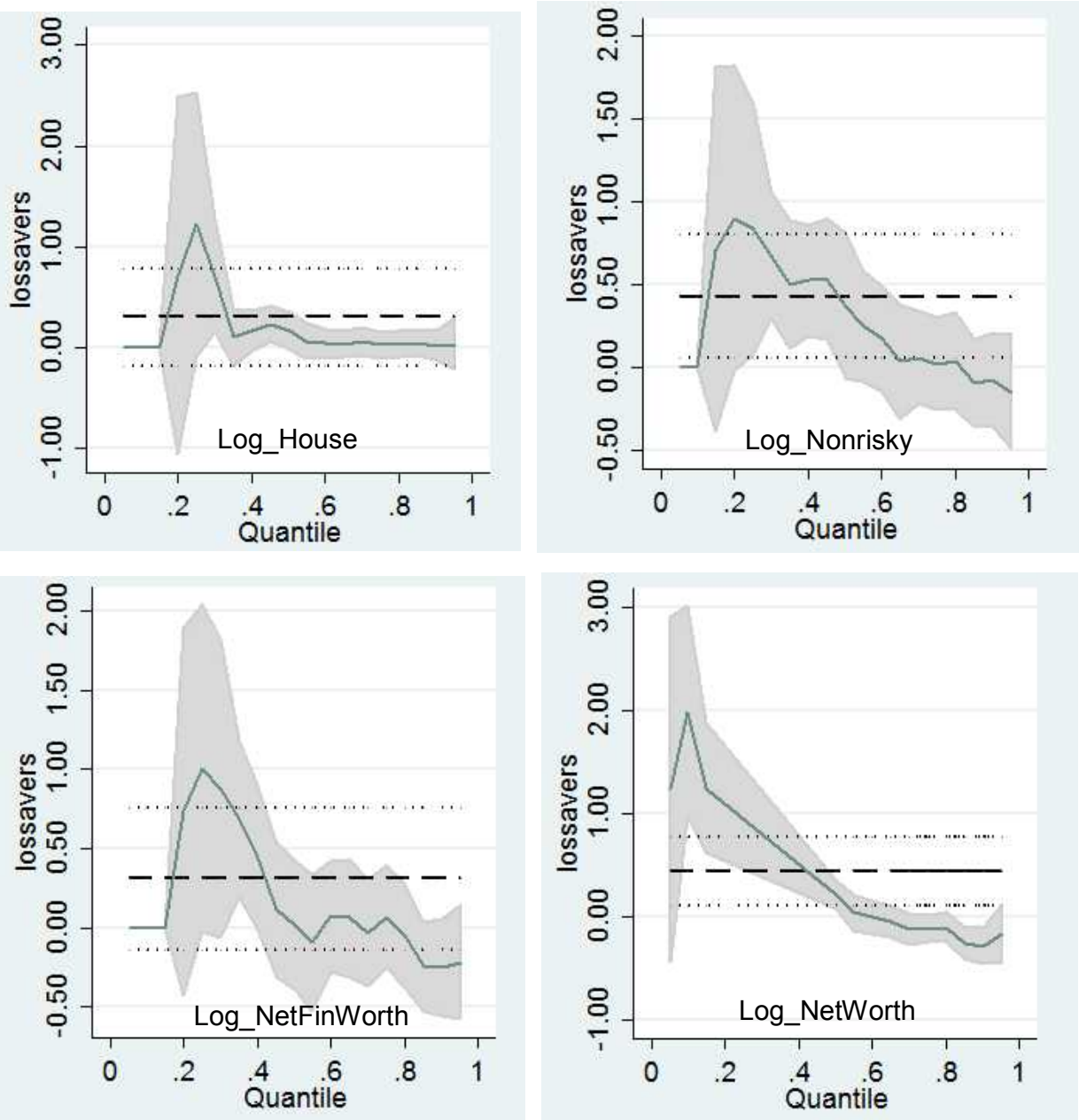

Notes: Shaded regions indicate the $95 \%$ confidence interval of quantile regressions when dependent variables are log_House, log_Nonrisky, log_NetFinWorth, and log_NetWorth (columns (2)-(5) of Table 11). Bold lines in the center of the shaded regions indicate the effects of loss aversion on log_House (by qunatiles of log_House), log_Nonrisky (by quantiles of log_Nonrisky), log_NetFinWorth (by quantiles of log_NetFinWorth), and on log_NetWorth (by quantiles of log_NetWorth). Straight dotted lines indicate the coefficient and $95 \%$ confidence intervals of OLS regressions. 


\section{Summary}

The modeling part of this paper examines how loss aversion would affect insurance buying decisions and savings decisions within the context of life cycle/permanent income savings model with a bequest motive. The five testable predictions from the model are first derived and then tested empirically. Loss aversion is measured by respondents' attitudes toward small-amount risky investments (e.g., equal chances of receiving $\$ 115$ or paying $\$ 100 ; \ldots$; receiving $\$ 300$ or paying $\$ 100$ ) in the HRS 2012. This paper focuses on the three types of assets that differ from each other in the insurance vs. savings element: (1) term-life insurance (pure insurance), (2) whole-life insurance (partial insurance + partial savings), and (3) net worth (savings).

First three predictions ([A1]-[A3]) can be summarized as follows: while loss aversion decreases the demand for pure insurance (term-life insurance), it may increase the demand for savings (net worth). Loss-aversion may have either a negative or a positive impact on the holdings of whole-life insurance, since whole-life insurance is a combination of pure insurance and savings. The sign of the impact will be determined by the proportion of protection vs. savings elements that a whole-life insurance plan contains. Empirical test results using the HRS data set are consistent with these predictions. Loss-averse elderly people have a significantly low ownership ratio of term-life insurance. They also have a lower number of term-life policies and lower coverage amounts of term-life insurance. In contrast, loss-averse elderly people possess higher levels of net worth than others in the form of non-risky assets. In its relationship with whole-life insurance, loss-aversion shows a positive association with whole-life insurance holdings, but its statistical significance is less robust. This occasional positive association is consistent with the fact that whole-life insurance held by the elderly has considerable savings elements.

The model's fourth prediction ([A4]) is that two weights for bequests (bequest weight for the death at $t+1$ vs. bequest weight for the death at $t+2$ ) have different impacts on term-life insurance and savings. In particular, the model predicts that an increase in the bequest weight for $t+2$ (expected death) 
would decrease the demand for term-life insurance, while it would increase the demand for savings. Empirical results are in line with this prediction. The bequest motive for expected death as measured by an indicator variable for having a written will is not significant in the regressions for term-life insurance holdings but significant with a positive sign in the regressions for whole-life insurance holdings. The indicator variable for the bequest motive shows the strongest association with levels of net worth, which represents pure savings.

The model's fifth prediction ([A5]) is that the effect of loss-aversion on the demand for term-life insurance is amplified by the expected survival probability and the degree of narrow framing. The findings are somewhat weaker but still consistent with this prediction. For example, the negative effect of loss aversion on the coverage amount of term-life is large among those who are confident that they would not die in the near future.

The results in this paper suggest that loss aversion, one of the most common behavioral tendencies, distorts the elderly's portfolio choice substantially, forcing the elderly to hold too little insurance and to save too much. ${ }^{17)}$ This implies that market failure or under-insurance problem may persist without government's intervention because the under-insurance problem is associated with the deep-rooted loss aversion parameter (Guiso, 2015). This in turn indicates that the provision of public insurance program may be needed to enhance public welfare. Another implication of this paper is that under-insurance may result in under-consumption through the channel of over-saving. As baby boomers enter their retirement years, the elderly's consumption will account for more and more proportion of total consumption. The results in this paper indicate that the provision of public insurance may be an effective measure to stimulate the elderly's consumption, thereby maintaining economic vitality in the aging society.

The limitations of this paper are as follows. First, the empirical results in this paper have a generalizability issue: this paper has not explored whether the same results hold for the young because the samples of the HRS are limited to

17) Hwang (2016b) discusses the socially optimal level of insurance when individuals are subject to loss aversion and narrow framing. 
those aged 51 and older by construction. Secondly, this paper uses several proxy measures to test the predictions of the insurance-savings model, but the proxy variables may be subject to measurement errors. For example, this paper measures the strength of the bequest motives for expected death using an indicator variable if an individual has a written will. The degree of narrow framing is proxied by the inverse of taking financial advice. It should be acknowledged that these proxy variables may be subject to measurement errors. Thirdly, the current version of this paper limits the analysis to a cross-sectional analysis. A dynamic analysis or panel study will help enrich and broaden our understandings of the topic.

※ STATA replication codes (including the instructions for downloading the HRS public data) are available at https://drive.google.com/open?id=0B2f2_rE_k61WRkxDSnFzMEVWdTA 


\section{References}

Aizenman, J. (1998), "Buffer Stocks and Precautionary Savings with Loss Aversion," Journal of international Money and Finance, Vol. 17(6), pp. 931-947.

Barberis, N. (2013), "Thirty Years of Prospect Theory in Economics: A Review and Assessment," Journal of Economic Perspectives, Vol. 27(1), pp. 173-196.

Barberis, N., M. Huang, and T. Santos (2001), "Prospect Theory And Asset Prices," Quarterly Journal of Economics, Vol. 116(1), pp. 1-53.

Barberis, N., M. Huang, and R. H. Thaler (2006), "Individual Preferences, Monetary Gambles, and Stock Market Participation: A Case for Narrow Framing," The American Economic Review, Vol. 96(4), pp. 1069-1090.

Barsky, R. B., F. T. Juster, M. S. Kimball, and M. D. Shapiro (1997), "Preference Parameters And Behavioral Heterogeneity: An Experimental Approach In The Health And Retirement Study," The Quarterly Journal of Economics.

Benartzi, S., and R. H. Thaler (1995), "Myopic Loss-aversion and the Equity Premium Puzzle," Quarterly Journal of Economics, Vol. 110, pp. 73-92.

Benartzi, S., and R. H. Thaler (2007), "Heuristics and Biases in Retirement Savings Behavior," The Journal of Economic Perspectives, Vol. 21(3), pp. 81-104.

Benartzi, S., A. Previtero, and R. H. Thaler (2011), "Annuitization Puzzles," The Journal of Economic Perspectives, Vol. 25(4), pp. 143-164.

Bernheim, B. D., K. G. Carman, J. Gokhale, and L. J. Kotlikoff (2003), "Are Life Insurance Holdings Related to Financial Vulnerabilities?" Economic Inquiry, Vol. 41(4), pp. 531-554.

Bernheim, B. D., L. Forni, J. Gokhale, and L. J. Kotlikoff (2003), "The Mismatch between Life Insurance Holdings and Financial Vulnerabilities: Evidence from the Health and Retirement Study," The American Economic Review, Vol. 93(1), pp. 354-365. 
Brown, J. R. (2001), "Are the Elderly Really Over-annuitized? New Evidence on Life Insurance and Bequests," In Themes in the Economics of Aging, University of Chicago Press, pp. 91-126.

Bhargava, S., G. Loewenstein, and J. Sydnor (2015), "Do Individuals Make Sensible Health Insurance Decisions? Evidence from a Menu with Dominated Options," National Bureau of Economic Research, No. w21160.

Bowman, D., D. Minehart, and M. Rabin (1999), "Loss Aversion in a Consumption -savings Model," Journal of Economic Behavior \& Organization, Vol. 38(2), pp. 155-178.

Brown, J. R. (2014), "Income as the Outcome: How to Broaden the Narrow Framing of U.S. Retirement Policy," Risk Management and Insurance Review, Vol. 17(1), pp. 7-16.

Brown, J. R., J. R. Kling, S. Mullainathan, and M. V. Wrobel (2008), "Why Don't People Insure Late-Life Consumption? A Framing Explanation of the Under-annuitization Puzzle," American Economic Review, Vol. 98(2), pp. 304-309.

Brown, J. R., J. R. Kling, S. Mullainathan, and M. V. Wrobel (2013), "Framing Lifetime Income," The Journal of Retirement, Vol. 1(1), pp. 27-37.

Camerer, C. F. (2004), "Prospect Theory in the Wild: Evidence from the Field," Advances in Behavioral Economics, pp. 148-161.

Cole, S., X. Giné, J. Tobacman, R. Townsend, P. Topalova, and J. Vickery (2013), "Barriers to Household Risk Management: Evidence from India," American economic journal. Applied economics, Vol. 5(1), p. 104.

Chetty, R. (2015), "Behavioral Economics and Public Policy: A Pragmatic Perspective," No. w20928, National Bureau of Economic Research.

Dimmock, S. G., and R. Kouwenberg (2010), "Loss-aversion and Household Portfolio Choice," Journal of Empirical Finance, Vol. 17(3), pp. 441-459. 
Dynan, K. E., J. Skinner, and S. P. Zeldes (2002), "The Importance of Bequests and Life-cycle Saving in Capital Accumulation: A New Answer," The American Economic Review, Vol. 92(2), pp. 274-278.

Dynan, K. E., J. Skinner, and S. P. Zeldes (2004), "Do the Rich Save More?" Journal of political economy, Vol. 112(2), pp. 397-444.

Fischer, S. (1973), "A Life Cycle Model of Life Insurance Purchases," International Economic Review, Vol. 14(1), pp. 132-152.

Frees, E. W., and Y. Sun (2010), "Household Life Insurance Demand: A Multivariate Two-part Model," North American Actuarial Journal, Vol. 14(3), pp. 338-354.

Gottlieb, D. (2012), "Prospect Theory, Life Insurance, and Annuities," The Wharton School Research Paper, No. 44.

Gottlieb, D., and O. S. Mitchell (2015), "Narrow Framing And Long-Term Care Insurance," Pension Research Council Working Papers, 2015-03, Wharton School Pension Research Council, University of Pennsylvania.

Greene, M. R. (1963), "Attitudes toward Risk and a Theory of Insurance Consumption," The Journal of Insurance, Vol. 30(2), pp. 165-182.

Greene, M. R. (1964), "Insurance Mindedness Implications for Insurance Theory," The Journal of Risk and Insurance, Vol. 31(1), pp. 27-38.

Guiso, L. (2015), "A Test of Narrow Framing and its Origin," Italian Economic Journal, Vol. 1(1), pp. 61-100.

Hwang, I. (2016a), "Prospect Theory and Insurance Demand. (February 3, 2016)," Available at SSRN: http://ssrn.com/abstract $=2586360$ or http://dx.doi.org/10.2139/ssm.2586360.

Hwang, I. (2016b), "Behavioral Welfare Analysis of Insurance Markets: The Case of Narrow Framing and Loss Aversion (July 20, 2016)," Available at SSRN: https://ssrn.com/abstract=2673273.

Johnson, E. J., J. Hershey, J. Meszaros, and H. Kunreuther (1993), "Framing, Probability Distortions, and Insurance Decisions," Journal of Risk and Uncertainty, Vol. 7(1), pp. 35-51. 
Kahneman, D. (2003), "Maps of Bounded Rationality: Psychology for Behavioral Economics," American Economic Review, Vol. 93(5), pp. 1449-1475.

Kahneman, D., and D. Lovallo (1993), "Timid Choices and Bold Forecasts: A Co gnitive Perspective on Risk Taking," Management science, Vol. 39(1), pp. $17-31$.

Kahneman, D., and A. Tversky (1979), "Prospect Theory: An Analysis of Decision under Risk," Econometrica: Journal of the Econometric Society, Vol. 47(2), pp. 263-292.

Köszegi, B., and M. Rabin (2009), "Reference-dependent Consumption Plans," The American Economic Review, Vol. 99(3), pp. 909-936.

Kotlikoff, L. J. (1988), "Intergenerational Transfers and Savings," Journal of Economic Perspectives, Vol. 2(2), pp. 41-58.

Kunreuther, H. C., M. V. Pauly, and S. McMorrow (2013), "Insurance and Behavioral Economics: Improving Decisions in the Most Misunderstood Industry," Cambridge University Press.

Levin, I. P., S. L. Schneider, and G. J. Gaeth (1998), "All Frames are Not Ceated Equal: A Typology and Critical Analysis of Framing Effects," Organizational Behavior and Human Decision Processes, Vol. 76(2), pp. 149-188.

LIMRA (2010), U.S. Life Ownership Study.

Mossin, J. (1968), “Aspects of Rational Insurance Purchasing," The Journal of Political Economy, Vol. 76(4), pp. 553-568.

Mountain, T. (2015), "Life Insurance and Financial Vulnerability," Doctoral Dissertatio $\mathrm{n}$, The Ohio State University.

Outreville, J. F. (2014), "Risk Aversion, Risk Behavior, and Demand for Insurance: A Survey," Journal of Insurance Issues, Vol. 37(2), pp. 158-186.

Pagel, M. (2016), "Expectations-based Reference-dependent Life-Cycle Consumption," Available at https://sites.google.com/site/michaelapagel/. 
Rabin, M. (2000), "Risk Aversion and Expected Utility Theory: A Calibration Theor em” Econometrica, Vol. 68(5), pp. 1281-1292.

Rabin, M., and R. H. Thaler (2001), "Anomalies: Risk Aversion," The Journal of Economic Perspectives, Vol. 15(1), pp. 219-232.

Safra, Z., and U. Segal (2008), "Calibration Results for Non-expected Utility Theories," Econometrica, Vol. 76(5), pp. 1143-1166.

Simon, H. A. (1957), "Models of Man: Social and Rational," John Wiley \& Sons, Inc., New York.

Tversky, A., and D. Kahneman (1981), "The Framing of Decisions and the Psychology of Choice," Science, Vol. 211(4481), pp. 453-458.

Tversky, A., and D. Kahneman (1992), "Advances in Prospect Theory: Cumulative Representation of Uncertainty," Journal of Risk and Uncertainty, Vol. 54, pp. 297-323.

Yaari, M. E. (1965), "Uncertain Lifetime, Life Insurance, and the Theory of the Consumer," The Review of Economic Studies, Vol. 32(2), pp. 137-150.

Zietz, E. N. (2003), "An Examination of the Demand for Life Insurance," Risk Management and Insurance Review, Vol. 6(2), pp. 159-191. 


\section{APPENDIX}

\section{Table A.1: Definitions and Sources of Variables}

\begin{tabular}{|c|c|c|}
\hline Variable & Related Question / Coding & HRS Code \\
\hline lossavers & $\begin{array}{l}\text { See Section } 4.1 \text {. This variable takes } 1.015,1.05,1.085,1.125 \text {, } \\
1.175,1.25,2.15 \text {, or } 3.15 \text {. }\end{array}$ & $\begin{array}{l}\text { NV014, NV015, } \\
\text { NV016, NV017 }\end{array}$ \\
\hline i_lossaver ( $\left.\begin{array}{ll}0 & 1\end{array}\right)$ & An indicator variable for high loss aversion $(\lambda=3.15)$ & " \\
\hline i_lossaver2 ( 0 1) & An indicator variable for loss aversion $(\lambda \geq 2.15)$ & " \\
\hline own_life $\left(\begin{array}{ll}0 & 1\end{array}\right)$ & $\begin{array}{l}\text { Do you have any life insurance, including individual or group } \\
\text { policies? IWER: Do not include burial insurance. ); Coded as } \\
\text { 1=Yes; 0=No }\end{array}$ & NT011 \\
\hline num_life & $\begin{array}{l}\text { How many different life insurance policies do you have? } \\
\text { IWER: Include individual policies, group policies, or paid-up } \\
\text { policies if R asks. }\end{array}$ & NT012 \\
\hline log_amt_life & $\begin{array}{l}\text { [What/Altogether, what] is the total face value of [this } \\
\text { policy/these policies], that is, the amount of money the } \\
\text { beneficiary would get if you were to die? ; Coded as } \ln (1+\text { face } \\
\text { value) }\end{array}$ & NT013 \\
\hline own_whole ( $\left(\begin{array}{ll}0 & 1\end{array}\right)$ & $\begin{array}{l}\text { [Is this a life insurance policy that builds/Are any of these life } \\
\text { insurance policies ones that build] up a cash value that you can } \\
\text { borrow against, or that you would receive if the policy were to } \\
\text { be cancelled? Def: (These are sometimes called 'Whole Life' or } \\
\text { 'Straight Life Policies.'); Coded as } 1=\text { Yes; 0=No }\end{array}$ & NT018 \\
\hline num_whole & How many such policies do you have? & NT019 \\
\hline log_amt_whole & $\begin{array}{l}\text { What is the current face value of [these policies/this policy]? } \\
\text { Coded as } \ln (1+\text { face value })\end{array}$ & NT020 \\
\hline own_term ( $\left.\begin{array}{ll}0 & 1\end{array}\right)$ & Author's imputation. See Section 4.2. & \\
\hline num_term & " & \\
\hline log_amt_term & $"$ & \\
\hline own2term ( $\left(\begin{array}{ll}0 & 1\end{array}\right)$ & $\begin{array}{l}\text { An indicator variable for owning two or more policies of term-life } \\
\text { insurance }\end{array}$ & \\
\hline log_amt_term50k & In(face value of term $-50,000) .^{\S}$ & \\
\hline will $\left(\begin{array}{ll}0 & 1\end{array}\right)$ & $\begin{array}{l}\text { Do you currently have a will that is written and witnessed?; } \\
\text { Coded as } 1 \text { if response is ' } 1 \text {. Yes, will,' '2. [vol] Yes, will and } \\
\text { trust,' or ' } 3 \text {. [vol] No will, but have trust'. Coded as } 0 \text { otherwise. }\end{array}$ & NT001 \\
\hline log_income \# & In(1+family income $)$ & H11ITOT* \\
\hline log_Stock \# & In $(1+$ net value of stocks, mutual funds, and investment trusts). & H11WSTCK* \\
\hline log_House \# & In $\left(1+\right.$ net value of primary residence). ${ }^{\S}$ & H11WTOTH* \\
\hline log_Nonrisky \# & $\begin{array}{l}\text { In (1+ 'value of checking, savings, or money market accounts' + 'value } \\
\text { of CD, government savings bonds, and T-bills' }+ \text { 'net value of bonds } \\
\text { and bond funds.' })\end{array}$ & $\begin{array}{l}\text { H11WCHCK* } \\
+ \text { H11WCD* } \\
+H 11 \text { WBOND* }\end{array}$ \\
\hline log_NetFinWorth \# & $\begin{array}{l}\text { In( } 1 \text { tthe net value of non-housing financial wealth (Stock + Nonrisky } \\
\text { +net value of all other saving-value of other debt other than mortgage, land loan, or } \\
\text { home loan)).\$. }\end{array}$ & H11WTOTN* \\
\hline log_NetWorth \# & In $(1+$ total net wealth including secondary residence $){ }^{\S}$ & H11WTOTB* \\
\hline
\end{tabular}


Table A.1: (Cont.)

\begin{tabular}{|c|c|c|}
\hline Variable & Related question / Coding & HRS Code \\
\hline own_house $\left(\begin{array}{ll}0 & 1\end{array}\right)$ & An indicator variable for house ownership & H11WOHOUS* \\
\hline edu & Years of education & NZ216 \\
\hline kids & Number of Resident and non-resident children & $\begin{array}{l}\text { NA099 + } \\
\text { NA100 }\end{array}$ \\
\hline employed ( $\left.\begin{array}{ll}0 & 1\end{array}\right)$ & $\begin{array}{l}\text { An indicator variable for currently working. Coded as } 1 \text { if } \\
\text { NJ005M1==1 (Working now), } 0 \text { otherwise. }\end{array}$ & NJ005M1 \\
\hline selfemp (l $\left.\begin{array}{ll}0 & 1\end{array}\right)$ & An indicator variable for self employers. & R11SLFEMP* \\
\hline cognitive & $\begin{array}{l}\text { Calculated Number Series Score (A high score indicates a high } \\
\text { cognitive ability). } \\
\text { ex) I would like you to write down the numbers from left to right } \\
\text { and then tell me what number goes in the blank based on the } \\
\text { pattern of numbers. } 2 \ldots 4 \ldots 6 \ldots \text { BLANK }\end{array}$ & NNSSCORE \\
\hline prob_live80100 & 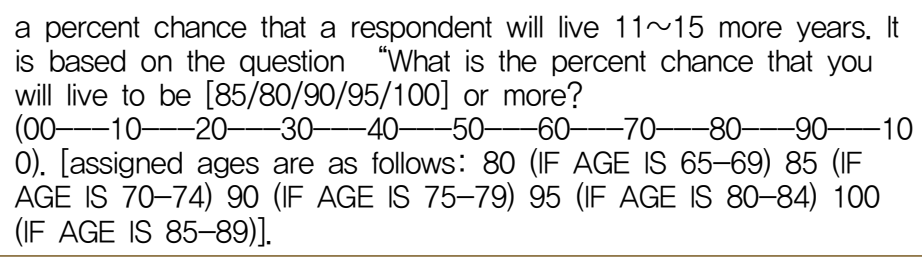 & NP029 \\
\hline livesure $\left(\begin{array}{ll}0 & 1\end{array}\right)$ & An indicator variable for 'prob_live80100 $\geq 90$ percent' & $"$ \\
\hline
\end{tabular}

An indicator variable for getting advice from financial experts. This is based on the 2014 HRS Module questions "Do you [and your[partner/husband/wife]] have someone such as a friend or relative, or bank officer, lawyer or financial consultant who regularly helps you with handling your money or property or other financial matters such as signing checks, paying bills, dealing with banks and making investments? [Yes/No]" and "[IF YES] Who helps

advice ( $\left.\begin{array}{ll}0 & 1\end{array}\right)$ you [and your [partner/husband/wife]] with your finances? 1.CHILD OR CHILD-IN-LAW 2.OTHER RELATIVE 3.FRIEND 4.LAWYER 5.BANK OFFICER 6.FINANCIAL CONSULTANT, ACCOUNTANT OR OTHER PROFESSIONAL INVESTMENT COUNSELOR 7.OTHER, SPECIFY." The value of zero is assigned if a respondent chooses "No" to the first question or " $1 \sim 4$, or 7 " to the second question. The value of one is assigned if a respondent choose Yes in the first question and (5 or 6 ) in the second question (getting help from financial experts).

This variable takes $1,2,3,4,5$, or 6 . It is based on the question, "Suppose that you are the only income earner in the family. Your doctor recommends that you move because of allergies, and you have to choose between two possible jobs. The first would guarantee your current total family income for life. The second is

riskavers possibly better paying, but the income is also less certain. There is r8risk6* a 50-50 chance the second job would double your total lifetime income and a 50-50 chance that it would cut it by a third [by seventy-five percent; in half; by twenty percent; by 10 percent]. Which job would you take - the first job or the second job?" See Barsky et al. (1997)

Notes: \# indicates household-level data; individual-level data otherwise. $\S$ indicates that the value in the log is replaced with one if the original value is less than one. * indicates that the source of the data is "RAND HRS Income and Wealth Imputations-v.O (March 2016)." 
Table A.2: Descriptive Statistics of Variables (2012 HRS Sample Aged 60 or More and Loss-aversion Data is Available)

\begin{tabular}{|c|c|c|c|c|c|c|c|c|}
\hline \multirow{2}{*}{ Variable } & \multirow{2}{*}{ Mean } & \multirow[b]{2}{*}{ S.D. } & \multicolumn{5}{|c|}{ Quantiles } & \multirow{2}{*}{ obs } \\
\hline & & & Min & Q1 & Median & Q3 & Max & \\
\hline lossavers & 2.76 & $(0.69)$ & 1.01 & 2.15 & 3.15 & 3.15 & 3.15 & 1,100 \\
\hline i_lossaver & 0.72 & $(0.45)$ & 0 & 0 & 1 & 1 & 1 & 1,100 \\
\hline i_lossaver2 & 0.89 & $(0.31)$ & 0 & 1 & 1 & 1 & 1 & 1,100 \\
\hline own_life & 0.57 & $(0.50)$ & 0 & 0 & 1 & 1 & 1 & 1,095 \\
\hline num_life & 0.85 & $(0.95)$ & 0 & 0 & 1 & 1 & 5 & 1,087 \\
\hline log_amt_life & 5.4 & $(5.18)$ & 0 & 0 & 8.52 & 10.13 & 15.42 & 1,001 \\
\hline own_term & 0.36 & $(0.48)$ & 0 & 0 & 0 & 1 & 1 & 1,051 \\
\hline num_term & 0.48 & $(0.75)$ & 0 & 0 & 0 & 1 & 5 & 1,050 \\
\hline log_amt_term & 3.26 & $(4.85)$ & 0 & 0 & 0 & 9.21 & 15.42 & 987 \\
\hline own2term & 0.09 & $(0.29)$ & 0 & 0 & 0 & 0 & 1 & 1,050 \\
\hline log_amt_term50k & 1.17 & (3.47) & 0 & 0 & 0 & 0 & 15.41 & 987 \\
\hline own_whole & 0.27 & $(0.44)$ & 0 & 0 & 0 & 1 & 1 & 1,051 \\
\hline num_whole & 0.35 & $(0.66)$ & 0 & 0 & 0 & 1 & 4 & 1,048 \\
\hline log_amt_whole & 1.06 & (3.12) & 0 & 0 & 0 & 0 & 12.71 & 862 \\
\hline will & 0.58 & $(0.49)$ & 0 & 0 & 1 & 1 & 1 & 1,095 \\
\hline log_income & 10.31 & $(1.27)$ & 0 & 9.74 & 10.37 & 10.99 & 14.22 & 1,100 \\
\hline log_Stock & 2.59 & $(4.85)$ & 0 & 0 & 0 & 0 & 15.42 & 1,100 \\
\hline log_House & 8.6 & (5.16) & 0 & 0 & 11.29 & 12.09 & 14.91 & 1,100 \\
\hline log_Nonrisky & 7.41 & $(4.27)$ & 0 & 5.53 & 8.66 & 10.71 & 14.65 & 1,100 \\
\hline log_NetFinWorth & 7.31 & $(5.10)$ & 0 & 0 & 9.21 & 11.46 & 15.52 & 1,100 \\
\hline log_NetWorth & 10.86 & (3.93) & 0 & 10.48 & 12.07 & 13.17 & 16.37 & 1,100 \\
\hline age & 72.26 & (8.43) & 60 & 65 & 72 & 78 & 99 & 1,100 \\
\hline edu & 12.63 & (3.03) & 0 & 12 & 12 & 14 & 17 & 1,093 \\
\hline kids & 3.25 & (2.08) & 0 & 2 & 3 & 4 & 20 & 1,100 \\
\hline employed & 0.21 & $(0.41)$ & 0 & 0 & 0 & 0 & 1 & 1,100 \\
\hline selfemp & 0.08 & $(0.27)$ & 0 & 0 & 0 & 0 & 1 & 1,100 \\
\hline cognitive & 516.67 & (34.36) & 409 & 501 & 519 & 537 & 584 & 943 \\
\hline prob_live80100 & 46.04 & (31.62) & 0 & 20 & 50 & 75 & 100 & 1,021 \\
\hline livesure & 0.12 & $(0.32)$ & 0 & 0 & 0 & 0 & 1 & 1,021 \\
\hline advice & 0.12 & (0.33) & 0 & 0 & 0 & 0 & 1 & 97 \\
\hline married & 0.57 & $(0.50)$ & 0 & 0 & 1 & 1 & 1 & 1,100 \\
\hline female & 0.59 & $(0.49)$ & 0 & 0 & 1 & 1 & 1 & 1,100 \\
\hline i_hispanic & 0.09 & $(0.29)$ & 0 & 0 & 0 & 0 & 1 & 1,100 \\
\hline own_house & 0.78 & $(0.41)$ & 0 & 1 & 1 & 1 & 1 & 1,100 \\
\hline riskavers & 4.75 & (1.43) & 1 & 4 & 5 & 6 & 6 & 373 \\
\hline health_status & 2.88 & $(1.09)$ & 1 & 2 & 3 & 4 & 5 & 1,098 \\
\hline share_stock & 6.60 & (16.74) & 0 & 0 & 0 & 0 & 100 & 1,001 \\
\hline share_house & 43.39 & $(34.47)$ & 0 & 11.88 & 38.5 & 76.27 & 100 & 1,001 \\
\hline share_nonrisky & 16.64 & (25.64) & 0 & 0.58 & 5.04 & 20 & 100 & 1,001 \\
\hline
\end{tabular}

Note: See Table A.1 for definitions of variables. 
Table A.3: Characteristics of the Analyzed 2012 HRS Sample: Comparison with 2012 CPS

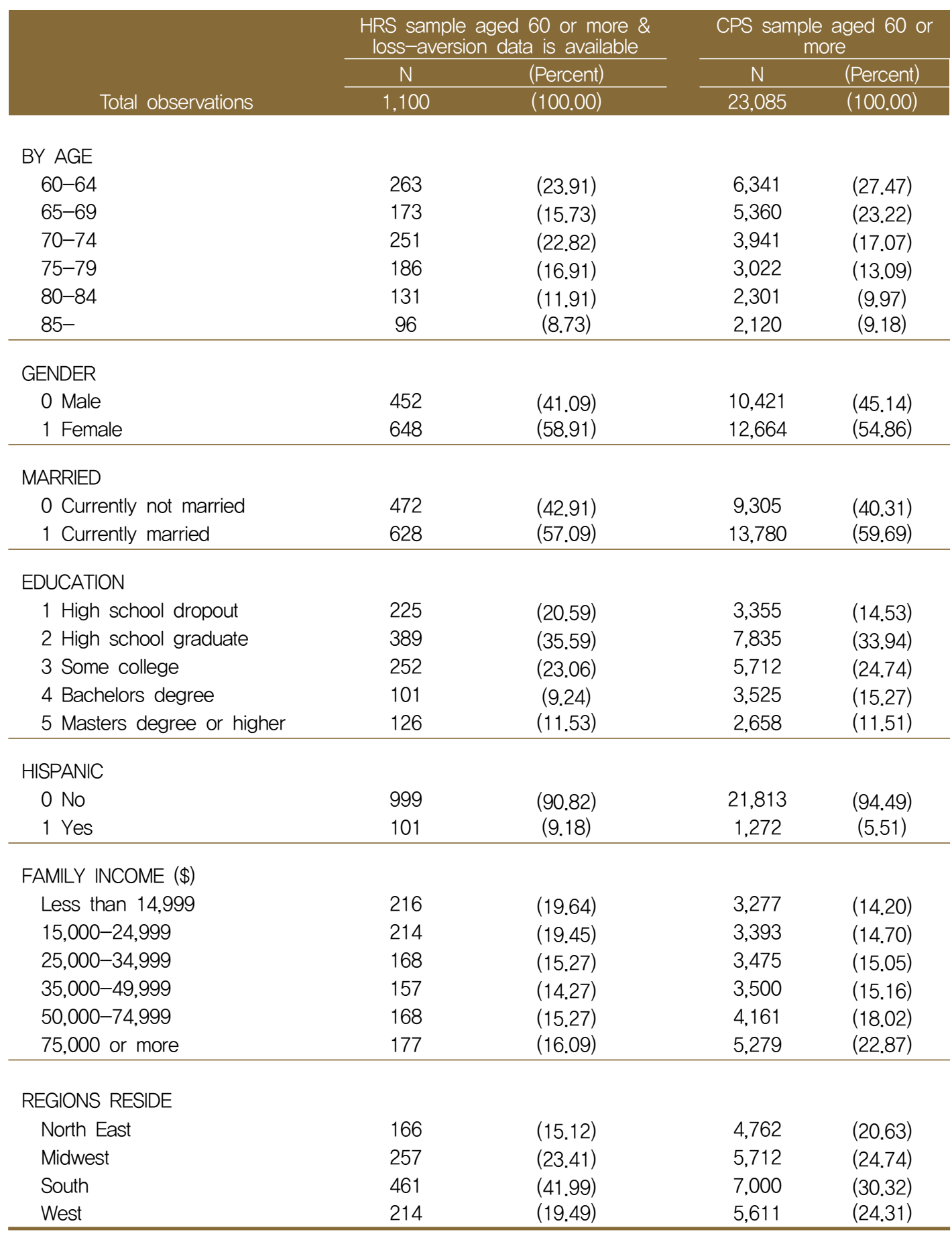

Notes: The analyzed HRS samples are those who are aged 60 or more and loss aversion data is available. Current Population Survey (CPS) samples are based on July 2012 survey. All figures are based on unweighted data. 
Table A.4: Demography of Loss Aversion and Risk Aversion (Age $\geq 60$ )

\begin{tabular}{|c|c|c|c|c|c|c|c|c|c|c|}
\hline & Male & Female & $\begin{array}{l}\text { Age } \\
60-70\end{array}$ & $70-80$ & $\begin{array}{c}\text { Not } \\
\text { currently } \\
\text { married }\end{array}$ & $\begin{array}{l}\text { Currently } \\
\text { Married }\end{array}$ & $\begin{array}{l}\text { edu } \\
\langle=12\end{array}$ & edu>12 & kids $\langle=2$ & kids $>3$ \\
\hline \multirow{4}{*}{$\begin{array}{l}N \\
\text { lossavers } \\
(1.015,1.05, \ldots, 3.15) \\
(\mathrm{s} . \mathrm{d})\end{array}$} & 452 & 648 & 436 & 437 & 472 & 628 & 614 & 486 & 464 & 636 \\
\hline & 2.70 & 2.80 & 2.69 & 2.80 & 2.76 & 2.76 & 2.78 & 2.73 & 2.79 & 2.74 \\
\hline & $(0.72)$ & (0.66) & $(0.71)$ & (0.69) & $(0.68)$ & $(0.70)$ & (0.67) & $(0.71)$ & $(0.67)$ & $(0.70)$ \\
\hline & Male & Female & $\begin{array}{l}\text { Age } \\
60-70\end{array}$ & $70-80$ & $\begin{array}{c}\text { Not } \\
\text { currently } \\
\text { married }\end{array}$ & $\begin{array}{l}\text { Currently } \\
\text { Married }\end{array}$ & $\begin{array}{l}\text { edu } \\
\langle=12\end{array}$ & edu>12 & kids $<=2$ & kids $>3$ \\
\hline$N$ & 1,671 & 2,550 & 3,701 & 520 & 1,494 & 2,727 & 1,954 & 3,178 & 2,046 & 3,086 \\
\hline $\begin{array}{l}\text { riskavers } \\
(1,2,3,4,5,6)\end{array}$ & 4.58 & 4.84 & 4.73 & 4.80 & 4.69 & 4.76 & 4.92 & 4.59 & 4.70 & 4.73 \\
\hline (s.d) & (0.53) & $(1.41)$ & $(1.46)$ & $(1.48)$ & (1.53) & $(1.43)$ & (1.44) & (1.50) & (1.43) & (1.53) \\
\hline
\end{tabular}

Notes: See Table A.1 for definitions of lossavers and riskavers. This table shows that female, old, and undereducated individuals are more likely to be loss-averse. Risk aversion also exhibits a similar pattern. The correlation of coefficient (between loss aversion and risk aversion is estimated to be $0.1095(\mathrm{~N}=373$, p-value=0.0345).

Source: 2012 HRS. RAND HRS Data File (v.O) (Feb 2016) 
Table A.5: Life Insurance Ownership Ratio of the U.S. Elderly in 2012 (Ageindividual-level, Unweighted)

\begin{tabular}{|c|c|c|c|c|c|c|}
\hline $\begin{array}{l}\text { BY AGE } \\
(\mathrm{N})\end{array}$ & $\begin{array}{l}51-59 \\
(5,620)\end{array}$ & $\begin{array}{l}60-69 \\
(5,018)\end{array}$ & $\begin{array}{l}70-79 \\
(5,042)\end{array}$ & $\begin{array}{l}80-89 \\
(2,361)\end{array}$ & $\begin{array}{c}90 \text { or older } \\
(534)\end{array}$ & $\begin{array}{c}\text { Total } \\
(18,575)\end{array}$ \\
\hline Any life insurance $(a+b-c)$ & 0.582 & 0.583 & 0.550 & 0.512 & 0.403 & 0.560 \\
\hline term-life(a) & 0.453 & 0.407 & 0.326 & 0.296 & 0.242 & 0.380 \\
\hline whole-life(b) & 0.211 & 0.255 & 0.294 & 0.280 & 0.197 & 0.254 \\
\hline both types (c ) & 0.082 & 0.079 & 0.070 & 0.064 & 0.036 & 0.074 \\
\hline $\begin{array}{l}\text { BY GENDER } \\
(\mathrm{N})\end{array}$ & $\begin{array}{l}\text { Male } \\
(7,947)\end{array}$ & $\begin{array}{l}\text { Female } \\
(10,627)\end{array}$ & $\begin{array}{c}\text { Total } \\
(18,574)\end{array}$ & & & \\
\hline Any life insurance $(a+b-c)$ & 0.602 & 0.528 & 0.560 & & & \\
\hline term-life(a) & 0.416 & 0.353 & 0.380 & & & \\
\hline whole-life(b) & 0.276 & 0.237 & 0.254 & & & \\
\hline both types (c ) & 0.091 & 0.062 & 0.074 & & & \\
\hline $\begin{array}{l}\text { BY CURRENT MARITAL STATUS } \\
(\mathrm{N})\end{array}$ & $\begin{array}{l}\text { Not married } \\
\text { orcoupled } \\
(7,968)\end{array}$ & $\begin{array}{c}\text { Married or } \\
\text { coupled } \\
(10,606)\end{array}$ & $\begin{array}{c}\text { Total } \\
(18,574)\end{array}$ & & & ' \\
\hline Any life insurance $(a+b-c)$ & 0.485 & 0.616 & 0.560 & & & \\
\hline term-life(a) & 0.322 & 0.423 & 0.380 & & & \\
\hline whole-life(b) & 0.214 & 0.283 & 0.254 & & & \\
\hline both types (c ) & 0.052 & 0.091 & 0.074 & & & \\
\hline $\begin{array}{l}\text { BY THE NUMER OF KIDS } \\
(\mathrm{N})\end{array}$ & $\begin{array}{c}0 \\
(1,467)\end{array}$ & $\begin{array}{c}1 \\
(1,940)\end{array}$ & $\begin{array}{c}2 \\
(5,018)\end{array}$ & $\begin{array}{c}3 \\
(3,908)\end{array}$ & $\begin{array}{l}4 \text { or more } \\
(6,242)\end{array}$ & $\begin{array}{c}\text { Total } \\
(18,575)\end{array}$ \\
\hline Any life insurance $(a+b-c)$ & 0.487 & 0.567 & 0.605 & 0.594 & 0.516 & 0.560 \\
\hline term-life(a) & 0.344 & 0.387 & 0.413 & 0.408 & 0.343 & 0.380 \\
\hline whole-life(b) & 0.202 & 0.254 & 0.276 & 0.273 & 0.236 & 0.254 \\
\hline both types (c ) & 0.059 & 0.074 & 0.083 & 0.086 & 0.062 & 0.074 \\
\hline $\begin{array}{l}\text { BY HOUSEHOLD NET WORTH } \\
(\mathrm{N})\end{array}$ & $\begin{array}{c}\text { Bottom } 25 \% \\
(4,557)\end{array}$ & $\begin{array}{c}25-50 \% \\
(4,583)\end{array}$ & $\begin{array}{c}50-75 \% \\
(4,679)\end{array}$ & $\begin{array}{c}\text { Top } 25 \% \\
(4,756)\end{array}$ & $\begin{array}{c}\text { Total } \\
(18,575)\end{array}$ & \\
\hline Any life insurance $(a+b-c)$ & 0.407 & 0.582 & 0.638 & 0.607 & 0.560 & \\
\hline term-life(a) & 0.280 & 0.403 & 0.442 & 0.393 & 0.380 & \\
\hline whole-life(b) & 0.161 & 0.240 & 0.295 & 0.315 & 0.254 & \\
\hline both types (c ) & 0.034 & 0.062 & 0.099 & 0.100 & 0.074 & \\
\hline $\begin{array}{l}\text { BY EDUCATION } \\
(\mathrm{N})\end{array}$ & $\begin{array}{c}\text { Highschool } \\
\text { Dropout } \\
(3,889)\end{array}$ & $\begin{array}{c}\text { Highschool } \\
\text { Graduate } \\
(5,743)\end{array}$ & $\begin{array}{l}\text { Some } \\
\text { College } \\
(4,327)\end{array}$ & $\begin{array}{c}\text { Bachelor's } \\
\text { Degree } \\
(2,225)\end{array}$ & $\begin{array}{c}\text { Gradiate } \\
\text { Degree } \\
(2,047)\end{array}$ & $\begin{array}{c}\text { Total } \\
(18,231)\end{array}$ \\
\hline Any life insurance $(a+b-c)$ & 0.392 & 0.576 & 0.605 & 0.644 & 0.649 & 0.560 \\
\hline term-life(a) & 0.247 & 0.374 & 0.415 & 0.476 & 0.471 & 0.380 \\
\hline whole-life(b) & 0.174 & 0.270 & 0.268 & 0.288 & 0.297 & 0.254 \\
\hline both types (c ) & 0.030 & 0.068 & 0.078 & 0.120 & 0.119 & 0.074 \\
\hline
\end{tabular}

Notes: This table displays the ownership ratio of life insurance of the U.S. elderly. It shows that 56.0 percent of those aged 51 or older have life insurance. By demographic characteristics, wealthy, highly educated, male and married individuals and those with kids are more likely to hold life insurance.

Data Source: 2012 HRS 
Table A.6: Loss Aversion and Term-Life \& Whole-life Insurance: All HRS Samples

\begin{tabular}{l|cccc|c} 
& \multicolumn{2}{|c}{$\begin{array}{c}\text { Those with low } \\
\text { loss aversion }(\lambda \leq 2.15)\end{array}$} & $\begin{array}{r}\text { Those with high } \\
\text { loss aversion }(\lambda=3.15) \\
N=1,087\end{array}$ & $\begin{array}{c}\text { Two tailed t-test for } \\
\text { equal mean } \\
\text { p-value }\end{array}$ \\
\hline own_term & 0.431 & $(0.021)$ & 0.373 & $(0.015)$ & $0.023^{* *}$ \\
num_term & 0.589 & $(0.034)$ & 0.504 & $(0.024)$ & $0.040^{* *}$ \\
log_amt_term & 4.442 & $(0.241)$ & 3.520 & $(0.159)$ & $0.001^{* * *}$ \\
\hline own_whole & 0.243 & $(0.018)$ & 0.254 & $(0.013)$ & 0.628 \\
num_whole & 0.291 & $(0.024)$ & 0.327 & $(0.020)$ & 0.267 \\
log_amt_whole & 1.094 & $(0.151)$ & 1.078 & $(0.104)$ & 0.927 \\
\hline
\end{tabular}

Notes: Standard errors in parentheses. ${ }^{* *} p<0.01, * * p<0.05, * p<0.1$.

Sources: 2012 HRS

\section{Table A.7 Robustness Check 1: Further Control of Employer-provided Term-life Plans (Age $\geq 60$ )}

Panel A

\begin{tabular}{|c|c|c|c|c|}
\hline & $\begin{array}{l}\text { (1) Probit } \\
\text { own_2term }\end{array}$ & $\begin{array}{l}\text { (2) Probit } \\
\text { own_2term }\end{array}$ & $\begin{array}{c}\text { (3) Tobit } \\
\text { log_amt_term50k }\end{array}$ & $\begin{array}{c}\text { (4) Tobit } \\
\text { log_amt_term50k }\end{array}$ \\
\hline lossavers & $\begin{array}{c}-0.153^{* *} \\
(0.0723)\end{array}$ & $\begin{array}{c}-0.151^{* *} \\
(0.0744)\end{array}$ & $\begin{array}{c}-3.336^{* *} \\
(1.371)\end{array}$ & $\begin{array}{l}-1.782 \\
(1.183)\end{array}$ \\
\hline will & & $\begin{array}{c}0.119 \\
(0.137)\end{array}$ & & $\begin{array}{c}5.639 * * * \\
(2.144)\end{array}$ \\
\hline log_income & & $\begin{array}{c}0.0597 \\
(0.0801)\end{array}$ & & $\begin{array}{c}0.862 \\
(0.982)\end{array}$ \\
\hline log_networth & & $\begin{array}{c}0.0103 \\
(0.0189)\end{array}$ & & $\begin{array}{c}0.486 \\
(0.360)\end{array}$ \\
\hline female & & $\begin{array}{c}-0.223^{*} \\
(0.114)\end{array}$ & & $\begin{array}{c}-7.620^{* * *} \\
(1.857)\end{array}$ \\
\hline married & & $\begin{array}{c}0.00129 \\
(0.136)\end{array}$ & & $\begin{array}{c}2.791 \\
(2.443)\end{array}$ \\
\hline age & & $\begin{array}{c}0.0397 \\
(0.0977)\end{array}$ & & $\begin{array}{c}-0.0598 \\
(2.739)\end{array}$ \\
\hline age_sq & & $\begin{array}{l}-0.000275 \\
(0.000659)\end{array}$ & & $\begin{array}{c}-0.00624 \\
(0.0194)\end{array}$ \\
\hline edu & & $\begin{array}{c}0.000765 \\
(0.0183)\end{array}$ & & $\begin{array}{c}1.151^{* * *} \\
(0.324)\end{array}$ \\
\hline kids & & $\begin{array}{l}-0.0402 \\
(0.0284)\end{array}$ & & $\begin{array}{c}0.600 \\
(0.445)\end{array}$ \\
\hline employed & & $\begin{array}{c}0.405^{* * *} \\
(0.137)\end{array}$ & & $\begin{array}{c}8.166^{* * *} \\
(1.921)\end{array}$ \\
\hline Constant & $\begin{array}{c}-0.901^{* * *} \\
(0.201)\end{array}$ & $\begin{array}{l}-3.009 \\
(3.665)\end{array}$ & $\begin{array}{c}-16.09^{* * *} \\
(4.125)\end{array}$ & $\begin{array}{l}-15.91 \\
(98.01)\end{array}$ \\
\hline Observations & 1,050 & 1,041 & 987 & 978 \\
\hline
\end{tabular}




\begin{tabular}{|c|c|c|c|c|c|c|}
\hline \multirow[b]{2}{*}{ VARIABLES } & \multicolumn{3}{|c|}{ Term-Life Insurance } & \multicolumn{3}{|c|}{ Whole-Life Insurance } \\
\hline & $\begin{array}{l}\text { (1) Probit } \\
\text { own_term }\end{array}$ & $\begin{array}{l}\text { (2) OLS } \\
\text { num_term }\end{array}$ & $\begin{array}{c}\text { (3) Tobit } \\
\text { log_amt_term }\end{array}$ & $\begin{array}{l}\text { (4) Probit } \\
\text { own_whole }\end{array}$ & $\begin{array}{c}\text { (5) OLS } \\
\text { num_whole }\end{array}$ & $\begin{array}{c}\text { (6) Tobit } \\
\text { log_amt_whole }\end{array}$ \\
\hline \multirow[t]{2}{*}{ lossavers } & $-0.103^{*}$ & $-0.0682^{* *}$ & $-1.265^{* *}$ & $0.107^{*}$ & $0.0475^{*}$ & 0.969 \\
\hline & $(0.0590)$ & $(0.0336)$ & $(0.605)$ & $(0.0627)$ & $(0.0282)$ & $(1.416)$ \\
\hline \multirow[t]{2}{*}{ will } & 0.00103 & 0.00203 & -0.0181 & $0.225^{* *}$ & $0.0948^{* *}$ & $5.515^{* *}$ \\
\hline & $(0.0989)$ & $(0.0581)$ & (1.063) & $(0.0999)$ & $(0.0452)$ & (2.225) \\
\hline \multirow[t]{2}{*}{ log_income } & 0.0325 & 0.0312 & 0.253 & 0.0196 & 0.0157 & 0.718 \\
\hline & $(0.0369)$ & $(0.0206)$ & (0.389) & $(0.0338)$ & $(0.0131)$ & $(0.830)$ \\
\hline \multirow{2}{*}{ log_networth } & $0.0317^{* *}$ & $0.0109^{*}$ & $0.314^{* *}$ & 0.00729 & 0.00428 & 0.250 \\
\hline & $(0.0136)$ & $(0.00604)$ & $(0.155)$ & $(0.0132)$ & $(0.00479)$ & $(0.313)$ \\
\hline \multirow[t]{2}{*}{ female } & -0.0357 & -0.0539 & 0.0135 & $-0.231^{* *}$ & $-0.146^{* * *}$ & $-7.501^{* * *}$ \\
\hline & $(0.0946)$ & $(0.0517)$ & $(1.027)$ & $(0.0954)$ & $(0.0506)$ & (2.007) \\
\hline \multirow[t]{2}{*}{ married } & -0.0403 & -0.00456 & 0.0143 & 0.000947 & 0.00988 & -0.323 \\
\hline & $(0.0980)$ & $(0.0549)$ & $(1.075)$ & $(0.101)$ & $(0.0478)$ & (2.233) \\
\hline \multirow[t]{2}{*}{ age } & -0.101 & -0.0534 & -0.922 & 0.136 & 0.0594 & 3.541 \\
\hline & $(0.0837)$ & $(0.0437)$ & (0.923) & $(0.0922)$ & $(0.0417)$ & $(2.227)$ \\
\hline \multirow[t]{2}{*}{ age_sq } & 0.000617 & 0.000331 & 0.00486 & -0.000952 & -0.000399 & -0.0244 \\
\hline & $(0.000563)$ & $(0.000290)$ & $(0.00625)$ & (0.000622) & $(0.000281)$ & $(0.0151)$ \\
\hline \multirow[t]{2}{*}{ edu } & $0.0436^{* * *}$ & 0.00850 & $0.565^{* * *}$ & 0.00850 & 0.00427 & 0.0659 \\
\hline & $(0.0156)$ & $(0.00743)$ & $(0.175)$ & $(0.0159)$ & $(0.00723)$ & $(0.370)$ \\
\hline \multirow[t]{2}{*}{ kids } & 0.00863 & -0.00652 & 0.113 & 0.0275 & 0.00495 & 0.0313 \\
\hline & $(0.0202)$ & $(0.00974)$ & $(0.216)$ & $(0.0206)$ & $(0.00925)$ & $(0.430)$ \\
\hline \multirow[t]{2}{*}{ employed } & $0.276^{* *}$ & $0.169^{* * *}$ & $3.351^{* * *}$ & 0.0923 & 0.0200 & $4.285^{*}$ \\
\hline & $(0.112)$ & $(0.0651)$ & (1.158) & $(0.116)$ & $(0.0529)$ & (2.466) \\
\hline \multirow[t]{2}{*}{ Constant } & 2.487 & 2.113 & 23.87 & $-6.258^{*}$ & -2.214 & $-163.4^{* *}$ \\
\hline & (3.083) & (1.610) & (33.95) & $(3.377)$ & $(1.503)$ & (79.98) \\
\hline occupation_dummies & $\mathrm{O}$ & 0 & 0 & 0 & $\mathrm{O}$ & 0 \\
\hline Observations & 1,042 & 1,041 & 978 & 1,042 & 1,039 & 854 \\
\hline R-squared & & 0.098 & & & 0.038 & \\
\hline
\end{tabular}

Notes: Robust standard errors in parentheses. *** p<0.01, ** $p<0.05, * p<0.1$. The dependent variable of columns (1)-(2) in Panel $A$ is an indicator variable for owning two or more policies of term-life insurance. The dependent variable of columns (3)-(4) is log of the "coverage amount of term-life insurance - \$50,000" (the dependent variable is replaced with 0 if the coverage amount is less than $\$ 50,001$ ). By using these dependent variables, we consider the possibility that one term-life insurance plan with the coverage amount of $\$ 50,000$ or less can be provided by employers. In Panel $\mathrm{B}$, we report regression results when 13 occupation dummy variables (based on industry codes with longest reported tenure) are added. 
Table A.8: Robustness Check 2: Low Wealth Level (Bottom Half) Individuals Only (Age $\geq 60)$

\begin{tabular}{|c|c|c|c|c|c|c|}
\hline & \multicolumn{3}{|c|}{ Term-Life Insurance } & \multicolumn{3}{|c|}{ Whole-Life Insurance } \\
\hline VARIABLES & $\begin{array}{l}\text { (1) Probit } \\
\text { own_term }\end{array}$ & $\begin{array}{l}\text { (2) OLS } \\
\text { num_term }\end{array}$ & $\begin{array}{l}\text { (3) Tobit } \\
\text { log_amt_term }\end{array}$ & $\begin{array}{l}\text { (4) Probit } \\
\text { own_whole }\end{array}$ & $\begin{array}{l}\text { (5) OLS } \\
\text { num_whole }\end{array}$ & $\begin{array}{c}\text { (6) Tobit } \\
\text { log_amt_whole }\end{array}$ \\
\hline \multirow[t]{2}{*}{ lossavers } & -0.132 & $-0.103^{* *}$ & $-1.577^{*}$ & 0.0957 & 0.0377 & 1.553 \\
\hline & $(0.0846)$ & $(0.0521)$ & $(0.911)$ & $(0.0882)$ & $(0.0418)$ & $(2.189)$ \\
\hline \multirow[t]{2}{*}{ will } & 0.183 & $0.165^{* *}$ & 1.606 & 0.184 & 0.0605 & 4.129 \\
\hline & $(0.132)$ & $(0.0818)$ & $(1.456)$ & $(0.134)$ & $(0.0656)$ & (2.999) \\
\hline \multirow[t]{2}{*}{ log_income } & 0.0624 & 0.0446 & 0.466 & 0.0666 & $0.0299^{*}$ & 1.774 \\
\hline & $(0.0724)$ & $(0.0422)$ & $(0.810)$ & $(0.0591)$ & $(0.0170)$ & (2.102) \\
\hline \multirow[t]{2}{*}{ log_networth } & $0.0483^{* * *}$ & $0.0224^{* * *}$ & $0.492^{* * *}$ & 0.0263 & $0.0127^{* *}$ & $0.838^{* *}$ \\
\hline & $(0.0163)$ & $(0.00740)$ & $(0.190)$ & $(0.0161)$ & $(0.00564)$ & $(0.406)$ \\
\hline \multirow[t]{2}{*}{ female } & 0.0215 & -0.0193 & 1.074 & -0.00218 & -0.0393 & -3.436 \\
\hline & $(0.128)$ & $(0.0772)$ & $(1.442)$ & $(0.129)$ & $(0.0576)$ & (2.892) \\
\hline \multirow[t]{2}{*}{ married } & -0.00234 & 0.0261 & 1.651 & 0.0118 & 0.0437 & 0.452 \\
\hline & $(0.140)$ & $(0.0936)$ & (1.566) & $(0.144)$ & $(0.0639)$ & (3.202) \\
\hline \multirow[t]{2}{*}{ age } & 0.0447 & 0.0567 & 0.692 & 0.158 & $0.0716^{*}$ & $6.382^{* *}$ \\
\hline & $(0.104)$ & $(0.0521)$ & (1.193) & $(0.111)$ & $(0.0432)$ & $(2.593)$ \\
\hline \multirow[t]{2}{*}{ age_sq } & -0.000364 & -0.000420 & -0.00589 & -0.00106 & $-0.000475^{*}$ & $-0.0421^{* *}$ \\
\hline & $(0.000695)$ & $(0.000346)$ & $(0.00806)$ & $(0.000742)$ & $(0.000285)$ & $(0.0173)$ \\
\hline \multirow[t]{2}{*}{ edu } & $0.0578^{* * *}$ & $0.0169^{*}$ & $0.813^{* * *}$ & 0.00842 & 0.00293 & -0.154 \\
\hline & $(0.0206)$ & $(0.00923)$ & $(0.244)$ & $(0.0207)$ & $(0.00897)$ & $(0.505)$ \\
\hline \multirow[t]{2}{*}{ kids } & -0.00674 & -0.0192 & 0.0159 & 0.0439 & 0.0107 & -0.403 \\
\hline & $(0.0282)$ & $(0.0147)$ & $(0.316)$ & $(0.0283)$ & $(0.0116)$ & $(0.685)$ \\
\hline \multirow[t]{2}{*}{ employed } & 0.187 & 0.119 & 2.224 & 0.213 & 0.0565 & 5.797 \\
\hline & $(0.160)$ & $(0.0942)$ & $(1.720)$ & $(0.168)$ & $(0.0788)$ & (3.773) \\
\hline \multirow[t]{2}{*}{ Constant } & -3.202 & -1.972 & -41.11 & $-7.979^{*}$ & $-2.921^{*}$ & $-288.0^{* * *}$ \\
\hline & (3.878) & $(1.961)$ & $(44.86)$ & $(4.133)$ & $(1.583)$ & (95.70) \\
\hline Observations & 518 & 517 & 491 & 520 & 520 & 425 \\
\hline R-squared & & 0.076 & & & 0.036 & \\
\hline
\end{tabular}

Notes: Robust standard errors in parentheses. $* * * p<0.01, * * p<0.05, * p<0.1$. This table displays the results when the sample is restricted to the bottom half of the original sample in terms of wealth levels. The results show that loss aversion is still significant at 5 percent level in the regression for num_term and is significant at 10 percent in the regression for log_amt_term. 
Table A.9: Robustness Check 3: A Risk Aversion Measure is Added (Age $\geq 60$ )

Panel A

\begin{tabular}{|c|c|c|c|c|c|c|}
\hline & \multicolumn{3}{|c|}{ Term-Life Insurance } & \multicolumn{3}{|c|}{ Whole-Life Insurance } \\
\hline VARIABLES & $\begin{array}{l}\text { (1) Probit } \\
\text { own_term }\end{array}$ & $\begin{array}{l}\text { (2) OLS } \\
\text { num_term }\end{array}$ & $\begin{array}{c}\text { (3) Tobit } \\
\text { log_amt_term }\end{array}$ & $\begin{array}{l}\text { (4) Probit } \\
\text { own_whole }\end{array}$ & $\begin{array}{l}\text { (5) OLS } \\
\text { num_whole }\end{array}$ & $\begin{array}{c}\text { (6) Tobit } \\
\text { log_amt_whole }\end{array}$ \\
\hline \multirow[t]{2}{*}{ lossavers } & $-0.171^{*}$ & $-0.138^{* *}$ & $-2.091^{* *}$ & $0.243^{* *}$ & $0.0913^{* *}$ & 3.276 \\
\hline & $(0.0981)$ & $(0.0643)$ & $(0.891)$ & $(0.115)$ & $(0.0355)$ & $(2.298)$ \\
\hline \multirow[t]{2}{*}{ riskaver } & 0.0161 & 0.0148 & -0.0436 & $-0.0945^{*}$ & -0.0299 & $-1.964^{*}$ \\
\hline & $(0.0502)$ & $(0.0285)$ & $(0.508)$ & $(0.0517)$ & $(0.0205)$ & $(1.082)$ \\
\hline \multirow[t]{2}{*}{ will } & 0.0334 & -0.0333 & 0.395 & 0.195 & 0.0714 & $7.953^{* *}$ \\
\hline & $(0.158)$ & $(0.110)$ & $(1.554)$ & $(0.172)$ & $(0.0679)$ & (3.752) \\
\hline \multirow[t]{2}{*}{ log_income } & 0.0288 & 0.0823 & -0.0302 & 0.0153 & 0.00181 & 0.271 \\
\hline & $(0.0985)$ & $(0.0574)$ & $(0.965)$ & $(0.0952)$ & $(0.0375)$ & $(2.448)$ \\
\hline \multirow[t]{2}{*}{ log_networth } & -0.00536 & -0.00118 & -0.0674 & $0.0706^{* * *}$ & $0.0200^{* * *}$ & $1.188^{* * *}$ \\
\hline & $(0.0211)$ & $(0.0123)$ & $(0.208)$ & $(0.0218)$ & $(0.00522)$ & $(0.442)$ \\
\hline \multirow[t]{2}{*}{ female } & -0.0834 & -0.104 & -0.478 & -0.145 & -0.0627 & $-6.692^{* *}$ \\
\hline & $(0.144)$ & $(0.0864)$ & $(1.440)$ & $(0.158)$ & $(0.0621)$ & (3.309) \\
\hline \multirow[t]{2}{*}{ married } & 0.188 & 0.0513 & 2.143 & -0.219 & -0.0724 & -6.551 \\
\hline & $(0.179)$ & $(0.103)$ & $(1.821)$ & $(0.200)$ & $(0.0824)$ & (4.424) \\
\hline \multirow[t]{2}{*}{ age } & 0.0337 & -0.160 & 1.254 & 1.133 & 0.260 & 13.00 \\
\hline & $(0.959)$ & $(0.590)$ & $(9.468)$ & $(1.067)$ & $(0.418)$ & (24.12) \\
\hline \multirow[t]{2}{*}{ age_sq } & -0.000564 & 0.00108 & -0.0130 & -0.00891 & -0.00211 & -0.103 \\
\hline & $(0.00736)$ & $(0.00450)$ & $(0.0728)$ & $(0.00819)$ & $(0.00320)$ & $(0.185)$ \\
\hline \multirow[t]{2}{*}{ edu } & $0.0634^{* *}$ & 0.0189 & $0.760^{* * *}$ & -0.00690 & -0.00576 & -0.0162 \\
\hline & $(0.0267)$ & $(0.0134)$ & $(0.272)$ & $(0.0287)$ & $(0.0110)$ & $(0.782)$ \\
\hline \multirow[t]{2}{*}{ kids } & -0.0133 & -0.0146 & -0.209 & 0.00450 & -0.00823 & -0.0847 \\
\hline & $(0.0380)$ & $(0.0220)$ & $(0.380)$ & $(0.0409)$ & $(0.0139)$ & $(0.872)$ \\
\hline \multirow[t]{2}{*}{ employed } & $0.360^{* *}$ & $0.204^{*}$ & $3.339^{* *}$ & 0.117 & 0.0506 & $7.894^{* *}$ \\
\hline & $(0.161)$ & $(0.119)$ & (1.593) & $(0.176)$ & $(0.0665)$ & (3.797) \\
\hline \multirow[t]{2}{*}{ Constant } & -0.875 & 5.628 & -32.79 & -37.65 & -7.876 & -446.6 \\
\hline & (31.24) & (19.29) & (307.3) & (34.63) & (13.56) & (778.2) \\
\hline Observations & 361 & 361 & 347 & 361 & 360 & 308 \\
\hline R-squared & & 0.091 & & & 0.056 & \\
\hline
\end{tabular}


Panel B

\begin{tabular}{|c|c|c|c|c|c|c|}
\hline & \multicolumn{3}{|c|}{ Term-Life Insurance } & \multicolumn{3}{|c|}{ Whole-Life Insurance } \\
\hline VARIABLES & $\begin{array}{l}\text { (1) Probit } \\
\text { own_term }\end{array}$ & $\begin{array}{l}\text { (2) OLS } \\
\text { num_term }\end{array}$ & $\begin{array}{c}\text { (3) Tobit } \\
\text { log_amt_term }\end{array}$ & $\begin{array}{l}\text { (4) Probit } \\
\text { own_whole }\end{array}$ & $\begin{array}{l}\text { (5) OLS } \\
\text { num_whole }\end{array}$ & $\begin{array}{c}\text { (6) Tobit } \\
\text { log_amt_whole }\end{array}$ \\
\hline \multirow[t]{2}{*}{ riskaver } & $0.0276^{* *}$ & 0.00735 & 0.174 & -0.00326 & -0.00192 & -0.136 \\
\hline & $(0.0140)$ & $(0.00833)$ & $(0.146)$ & $(0.0148)$ & $(0.00745)$ & $(0.323)$ \\
\hline \multirow[t]{2}{*}{ will } & 0.0502 & 0.0231 & 0.521 & $0.245^{* * *}$ & $0.100^{* * *}$ & $4.039^{* * *}$ \\
\hline & $(0.0453)$ & $(0.0274)$ & $(0.466)$ & $(0.0478)$ & $(0.0236)$ & $(1.092)$ \\
\hline \multirow[t]{2}{*}{ log_income } & 0.0254 & $0.0225^{* * *}$ & 0.259 & $0.0632^{* * *}$ & $0.0221^{* * *}$ & $1.333^{* * *}$ \\
\hline & $(0.0155)$ & $(0.00844)$ & $(0.167)$ & $(0.0191)$ & $(0.00539)$ & $(0.506)$ \\
\hline \multirow[t]{2}{*}{ log_networth } & 0.00702 & 0.00483 & 0.0950 & 0.00598 & 0.00408 & 0.112 \\
\hline & $(0.00594)$ & $(0.00314)$ & $(0.0633)$ & $(0.00647)$ & $(0.00255)$ & $(0.153)$ \\
\hline \multirow[t]{2}{*}{ female } & $-0.163^{* * *}$ & $-0.106^{* * *}$ & $-1.930^{* * *}$ & -0.0454 & $-0.0568^{* *}$ & $-2.868^{* * *}$ \\
\hline & $(0.0425)$ & $(0.0257)$ & $(0.437)$ & $(0.0446)$ & $(0.0222)$ & $(0.962)$ \\
\hline \multirow[t]{2}{*}{ married } & 0.0784 & 0.0348 & $0.846^{*}$ & 0.0720 & 0.0328 & 1.043 \\
\hline & $(0.0477)$ & $(0.0274)$ & $(0.503)$ & $(0.0504)$ & $(0.0229)$ & $(1.154)$ \\
\hline \multirow[t]{2}{*}{ age } & -0.0577 & -0.147 & 0.219 & 0.357 & -0.00914 & -4.278 \\
\hline & $(0.254)$ & $(0.136)$ & (2.710) & $(0.254)$ & $(0.124)$ & $(5.363)$ \\
\hline \multirow[t]{2}{*}{ age_sq } & 0.000249 & 0.00103 & -0.00386 & -0.00256 & 0.000136 & 0.0337 \\
\hline & $(0.00194)$ & $(0.00104)$ & $(0.0208)$ & (0.00194) & $(0.000950)$ & $(0.0410)$ \\
\hline \multirow[t]{2}{*}{ edu } & $0.0586^{* * *}$ & $0.0266^{* * *}$ & $0.651^{* * *}$ & 0.0116 & 0.00609 & $0.519^{* *}$ \\
\hline & $(0.00825)$ & $(0.00441)$ & $(0.0870)$ & $(0.00866)$ & $(0.00380)$ & $(0.216)$ \\
\hline \multirow[t]{2}{*}{ kids } & $0.0278^{* *}$ & $0.0160^{* *}$ & $0.270^{* *}$ & -0.0181 & -0.00809 & 0.0621 \\
\hline & $(0.0113)$ & $(0.00640)$ & $(0.116)$ & $(0.0119)$ & $(0.00509)$ & $(0.264)$ \\
\hline \multirow[t]{2}{*}{ employed } & $0.343^{* * *}$ & $0.203^{* * *}$ & $3.864^{* * *}$ & $0.130^{* * *}$ & $0.0664^{* * *}$ & $4.559^{* * *}$ \\
\hline & $(0.0455)$ & $(0.0280)$ & $(0.465)$ & $(0.0483)$ & $(0.0233)$ & $(1.045)$ \\
\hline \multirow[t]{2}{*}{ Constant } & 1.043 & 4.998 & -15.02 & $-13.97^{*}$ & -0.0160 & 90.67 \\
\hline & (8.260) & $(4.417)$ & (87.98) & (8.267) & $(4.017)$ & (174.6) \\
\hline Observations & 4,005 & 3,999 & 3,806 & 3,992 & 3,985 & 3,290 \\
\hline R-squared & & 0.056 & & & 0.029 & \\
\hline
\end{tabular}

Notes: Robust standard errors in parentheses. $* * * p<0.01, * * p<0.05,{ }^{*} p<0.1$. This table displays the regression results when a risk aversion measure (riskavers) is controlled for. The variable riskavers is measured by the status-quo-bias-free lifetime income gamble questions by Barsky et al. (1997) in the HRS. The variable takes the values of $1,2, \cdots$, or 6 . See Table A.1 for details. 
Table A.10: Robustness Check 4: Samples are Restricted to Those Aged 60-69

\begin{tabular}{|c|c|c|c|c|c|c|}
\hline \multirow[b]{2}{*}{ VARIABLES } & \multicolumn{3}{|c|}{ Term-Life Insurance } & \multicolumn{3}{|c|}{ Whole-Life Insurance } \\
\hline & $\begin{array}{l}\text { (1) Probit } \\
\text { own_term }\end{array}$ & $\begin{array}{l}\text { (2) OLS } \\
\text { num_term }\end{array}$ & $\begin{array}{c}\text { (3) Tobit } \\
\text { log_amt_term }\end{array}$ & $\begin{array}{l}\text { (4) Probit } \\
\text { own_whole }\end{array}$ & $\begin{array}{l}\text { (5) OLS } \\
\text { num_whole }\end{array}$ & $\begin{array}{c}\text { (6) Tobit } \\
\text { log_amt_whole }\end{array}$ \\
\hline \multirow[t]{2}{*}{ lossavers } & -0.146 & $-0.123^{* *}$ & $-1.959^{* *}$ & $0.179^{*}$ & $0.0784^{* *}$ & 2.614 \\
\hline & $(0.0911)$ & $(0.0556)$ & $(0.844)$ & $(0.0972)$ & $(0.0323)$ & (2.105) \\
\hline \multirow[t]{2}{*}{ will } & -0.0124 & -0.000245 & -0.292 & 0.172 & 0.0758 & 5.290 \\
\hline & $(0.147)$ & $(0.0941)$ & $(1.440)$ & $(0.155)$ & $(0.0677)$ & (3.478) \\
\hline \multirow[t]{2}{*}{ log_income } & 0.0603 & $0.0513^{*}$ & 0.563 & 0.0350 & 0.0149 & 0.897 \\
\hline & $(0.0697)$ & $(0.0309)$ & $(0.729)$ & (0.0533) & $(0.0176)$ & (1.645) \\
\hline \multirow[t]{2}{*}{ log_networth } & 0.0269 & 0.00890 & 0.288 & 0.0153 & 0.00744 & $1.135^{* *}$ \\
\hline & $(0.0190)$ & $(0.00934)$ & $(0.208)$ & $(0.0189)$ & $(0.00610)$ & $(0.500)$ \\
\hline \multirow[t]{2}{*}{ female } & -0.0684 & -0.0918 & -0.212 & -0.215 & $-0.143^{* *}$ & $-10.52^{* * *}$ \\
\hline & $(0.137)$ & $(0.0802)$ & $(1.371)$ & $(0.141)$ & $(0.0633)$ & (2.809) \\
\hline \multirow[t]{2}{*}{ married } & 0.100 & 0.0718 & 1.674 & -0.0365 & -0.0258 & -3.766 \\
\hline & $(0.163)$ & $(0.0874)$ & $(1.662)$ & $(0.171)$ & $(0.0732)$ & (3.737) \\
\hline \multirow[t]{2}{*}{ edu } & $0.0673^{* * *}$ & $0.0234^{* *}$ & $0.800^{* * *}$ & 0.0145 & 0.00296 & 0.474 \\
\hline & $(0.0228)$ & $(0.0100)$ & $(0.239)$ & $(0.0250)$ & $(0.00955)$ & $(0.720)$ \\
\hline \multirow[t]{2}{*}{ kids } & 0.0138 & -0.000402 & 0.126 & 0.0255 & -0.00263 & 0.564 \\
\hline & $(0.0350)$ & $(0.0193)$ & $(0.354)$ & $(0.0370)$ & $(0.0141)$ & $(0.825)$ \\
\hline \multirow[t]{2}{*}{ employed } & $0.430^{* * *}$ & $0.281^{* * *}$ & $3.912^{* * *}$ & 0.202 & 0.0919 & $5.961^{*}$ \\
\hline & $(0.138)$ & $(0.0848)$ & (1.372) & $(0.145)$ & $(0.0589)$ & (3.184) \\
\hline \multirow[t]{2}{*}{ Constant } & $-1.872^{* *}$ & -0.150 & $-18.90^{* *}$ & $-1.980^{* * *}$ & -0.140 & $-55.75^{* * *}$ \\
\hline & $(0.748)$ & $(0.351)$ & (7.694) & $(0.620)$ & $(0.195)$ & (16.65) \\
\hline Observations & 417 & 417 & 401 & 417 & 417 & 349 \\
\hline R-squared & & 0.111 & & & 0.048 & \\
\hline
\end{tabular}


Panel B

\begin{tabular}{|c|c|c|c|c|c|c|}
\hline \multirow[b]{2}{*}{ VARIABLES } & \multicolumn{3}{|c|}{ Term-Life Insurance } & \multicolumn{3}{|c|}{ Whole-Life Insurance } \\
\hline & $\begin{array}{l}\text { (1) Probit } \\
\text { own_term }\end{array}$ & $\begin{array}{l}\text { (2) OLS } \\
\text { num_term }\end{array}$ & $\begin{array}{c}\text { (3) Tobit } \\
\text { log_amt_term }\end{array}$ & $\begin{array}{l}\text { (4) Probit } \\
\text { own_whole }\end{array}$ & $\begin{array}{l}\text { (5) OLS } \\
\text { num_whole }\end{array}$ & $\begin{array}{c}\text { (6) Tobit } \\
\text { log_amt_whole }\end{array}$ \\
\hline \multirow[t]{2}{*}{ lossavers } & $-0.203^{*}$ & $-0.173^{* *}$ & $-2.339^{* *}$ & 0.183 & $0.0787^{* *}$ & 2.855 \\
\hline & $(0.105)$ & $(0.0688)$ & $(0.925)$ & $(0.120)$ & $(0.0382)$ & (2.338) \\
\hline \multirow[t]{2}{*}{ riskavers } & 0.0413 & 0.0318 & 0.238 & -0.0866 & -0.0241 & -1.520 \\
\hline & $(0.0563)$ & $(0.0319)$ & $(0.565)$ & $(0.0546)$ & $(0.0218)$ & $(1.129)$ \\
\hline \multirow[t]{2}{*}{ will } & -0.0162 & -0.0531 & -0.117 & 0.259 & 0.101 & $8.598^{* *}$ \\
\hline & $(0.169)$ & $(0.119)$ & $(1.611)$ & $(0.186)$ & $(0.0744)$ & (3.722) \\
\hline \multirow[t]{2}{*}{ log_income } & 0.0921 & 0.102 & 0.482 & -0.0347 & -0.0254 & -1.168 \\
\hline & $(0.113)$ & $(0.0639)$ & $(1.123)$ & $(0.105)$ & $(0.0418)$ & (2.488) \\
\hline \multirow[t]{2}{*}{ log_networth } & -0.0100 & -0.00293 & -0.0976 & $0.0736^{* * *}$ & $0.0193^{* * *}$ & $1.310^{* *}$ \\
\hline & $(0.0220)$ & $(0.0117)$ & $(0.210)$ & $(0.0251)$ & $(0.00566)$ & $(0.512)$ \\
\hline \multirow[t]{2}{*}{ female } & -0.111 & -0.134 & -0.693 & -0.146 & -0.0846 & $-9.074^{* * *}$ \\
\hline & $(0.155)$ & $(0.0951)$ & $(1.496)$ & $(0.168)$ & $(0.0691)$ & $(3.416)$ \\
\hline \multirow[t]{2}{*}{ married } & 0.257 & 0.128 & 2.963 & -0.162 & -0.0315 & -4.561 \\
\hline & $(0.195)$ & $(0.107)$ & $(1.955)$ & $(0.216)$ & $(0.0863)$ & $(4.541)$ \\
\hline \multirow[t]{2}{*}{ edu } & $0.0627^{* *}$ & 0.0214 & $0.752^{* *}$ & -0.0101 & -0.00375 & 0.0965 \\
\hline & $(0.0292)$ & $(0.0145)$ & $(0.291)$ & $(0.0312)$ & $(0.0127)$ & $(0.839)$ \\
\hline \multirow[t]{2}{*}{ kids } & -0.0128 & -0.00795 & -0.145 & -0.0126 & -0.0136 & 0.102 \\
\hline & $(0.0414)$ & $(0.0243)$ & $(0.407)$ & $(0.0435)$ & $(0.0144)$ & $(0.905)$ \\
\hline \multirow[t]{2}{*}{ employed } & $0.443^{* * *}$ & $0.264^{* *}$ & $4.155^{* * *}$ & 0.211 & 0.112 & $9.447^{* *}$ \\
\hline & $(0.165)$ & $(0.114)$ & $(1.578)$ & $(0.180)$ & $(0.0702)$ & (3.692) \\
\hline \multirow[t]{2}{*}{ Constant } & -1.756 & -0.488 & -12.62 & -1.141 & 0.313 & -26.52 \\
\hline & $(1.207)$ & $(0.648)$ & $(12.21)$ & $(1.105)$ & $(0.423)$ & (25.38) \\
\hline Observations & 311 & 311 & 299 & 311 & 311 & 266 \\
\hline R-squared & & 0.115 & & & 0.058 & \\
\hline
\end{tabular}

Notes: Robust standard errors in parentheses. ${ }^{* *} p<0.01,{ }^{* *} p<0.05,{ }^{*} p<0.1$. Panel $A$ of this table reports regression results when the sample is restricted to those in the same life-cycle stage, those aged 60-69 in particular. In Panel B, a risk aversion measure is added as an explanatory variable to this age cohort sample. Results show that even if a risk aversion measure is added to this age cohort sample, loss aversionís effects remain robust while risk-aversion is not significant. 
Table A.11: Robustness Check 5: Bivariate Probit, SUR, (Bivariate) Tobit Results (Age $\geq 60)$

\begin{tabular}{|c|c|c|c|c|c|c|c|c|}
\hline \multirow[b]{2}{*}{ VARIABLES } & \multicolumn{2}{|c|}{ Bivariate Probit } & \multicolumn{2}{|c|}{ SUR Regressions } & \multicolumn{2}{|c|}{ Bivariate Tobit } & \multicolumn{2}{|c|}{ (Separate Tobit) } \\
\hline & $\begin{array}{c}(1) \\
\text { own_term }\end{array}$ & $\begin{array}{c}\text { (2) } \\
\text { own_whole }\end{array}$ & $\begin{array}{c}\text { (3) } \\
\text { num_term }\end{array}$ & $\begin{array}{c}(4) \\
\text { num_whole }\end{array}$ & $\begin{array}{c}(5) \\
\text { log_amt_ } \\
\text { term }\end{array}$ & $\begin{array}{c}(6) \\
\text { log_amt__ } \\
\text { whole }\end{array}$ & $\begin{array}{c}(7) \\
\text { num_term }\end{array}$ & $\begin{array}{c}\text { (8) } \\
\text { num_whole }\end{array}$ \\
\hline \multirow[t]{2}{*}{ lossavers } & $-0.0967^{*}$ & 0.0986 & $-0.0666^{* *}$ & 0.0449 & $-1.066^{*}$ & 1.457 & $-0.155^{*}$ & 0.176 \\
\hline & $(0.0584)$ & $(0.0619)$ & $(0.0337)$ & $(0.0300)$ & $(0.618)$ & (1.540) & $(0.0857)$ & $(0.109)$ \\
\hline \multirow[t]{2}{*}{ will } & 0.0527 & $0.240^{* *}$ & 0.0337 & $0.0920^{*}$ & 0.585 & $5.448^{* *}$ & 0.0677 & $0.366^{* *}$ \\
\hline & $(0.0951)$ & $(0.100)$ & $(0.0535)$ & $(0.0477)$ & (1.019) & $(2.452)$ & $(0.145)$ & $(0.169)$ \\
\hline \multirow[t]{2}{*}{ log_income } & 0.0156 & 0.0225 & 0.0221 & 0.0189 & 0.144 & 0.690 & 0.0443 & 0.0706 \\
\hline & $(0.0360)$ & $(0.0334)$ & $(0.0205)$ & $(0.0183)$ & $(0.370)$ & $(1.025)$ & $(0.0588)$ & $(0.0624)$ \\
\hline \multirow[t]{2}{*}{ log_networth } & $0.0382^{* * *}$ & 0.00649 & $0.0153^{* *}$ & 0.00418 & $0.365^{* * *}$ & 0.319 & $0.0555^{* * *}$ & 0.0134 \\
\hline & $(0.0133)$ & $(0.0133)$ & $(0.00699)$ & $(0.00623)$ & $(0.139)$ & $(0.355)$ & $(0.0205)$ & $(0.0229)$ \\
\hline \multirow[t]{2}{*}{ female } & -0.117 & $-0.221^{* *}$ & $-0.0874^{*}$ & $-0.141^{* * *}$ & -0.903 & $-7.158^{* * *}$ & -0.202 & $-0.442^{* * *}$ \\
\hline & $(0.0852)$ & $(0.0875)$ & $(0.0482)$ & $(0.0430)$ & $(0.912)$ & $(2.177)$ & $(0.128)$ & $(0.151)$ \\
\hline \multirow[t]{2}{*}{ married } & -0.0368 & 0.0305 & 0.000594 & 0.0138 & 0.382 & -0.0723 & -0.0494 & 0.0224 \\
\hline & $(0.0968)$ & $(0.100)$ & $(0.0543)$ & $(0.0484)$ & $(1.042)$ & $(2.452)$ & $(0.149)$ & $(0.174)$ \\
\hline \multirow[t]{2}{*}{ age } & -0.0610 & 0.142 & -0.0235 & 0.0568 & -0.477 & $3.482^{*}$ & -0.0609 & 0.243 \\
\hline & $(0.0771)$ & $(0.0872)$ & $(0.0429)$ & $(0.0382)$ & $(0.868)$ & $(2.102)$ & $(0.115)$ & $(0.151)$ \\
\hline \multirow[t]{2}{*}{ age_sq } & 0.000329 & $-0.000983^{*}$ & 0.000119 & -0.000381 & 0.00168 & $-0.0240^{*}$ & 0.000296 & -0.00167 \\
\hline & $(0.000517)$ & $(0.000587)$ & $(0.000286)$ & $(0.000255)$ & $(0.00584)$ & $(0.0142)$ & $(0.000773)$ & $(0.00102)$ \\
\hline \multirow[t]{2}{*}{ edu } & $0.0427^{* * *}$ & 0.00458 & 0.0122 & 0.00282 & $0.516^{* * *}$ & 0.0749 & $0.0521^{* *}$ & 0.0123 \\
\hline & $(0.0143)$ & $(0.0151)$ & $(0.00828)$ & $(0.00738)$ & $(0.164)$ & $(0.359)$ & $(0.0214)$ & $(0.0262)$ \\
\hline \multirow[t]{2}{*}{ kids } & 0.00166 & 0.0201 & -0.0101 & 0.00355 & 0.161 & -0.132 & -0.0118 & 0.0325 \\
\hline & $(0.0199)$ & $(0.0205)$ & $(0.0113)$ & $(0.0101)$ & $(0.216)$ & $(0.528)$ & $(0.0295)$ & $(0.0352)$ \\
\hline \multirow[t]{2}{*}{ employed } & $0.214^{* *}$ & 0.114 & $0.147^{* *}$ & 0.0256 & $2.495^{* *}$ & 2.906 & $0.331^{* *}$ & 0.150 \\
\hline & $(0.108)$ & $(0.114)$ & $(0.0637)$ & $(0.0568)$ & (1.154) & (2.668) & $(0.158)$ & $(0.193)$ \\
\hline \multirow[t]{2}{*}{ Constant } & 1.467 & $-6.429^{* *}$ & 1.222 & -2.134 & 13.38 & $-160.9^{* *}$ & 1.105 & $-11.49^{* *}$ \\
\hline & (2.873) & (3.226) & (1.605) & $(1.431)$ & $(32.22)$ & $(79.50)$ & (4.294) & (5.583) \\
\hline \multirow[t]{2}{*}{ rho } & \multicolumn{2}{|c|}{$-0.232^{* * *}$} & & & \multicolumn{2}{|c|}{$0.208^{* * *}$} & & \\
\hline & \multicolumn{2}{|c|}{$(0.0563)$} & & & \multicolumn{2}{|c|}{$(0.0716)$} & & \\
\hline Observations & 1,039 & 1,039 & 1,036 & 1,036 & 811 & 811 & 1,041 & 1,039 \\
\hline R-squared & & & 0.047 & 0.030 & & & & \\
\hline
\end{tabular}

Notes: Robust standard errors in parentheses. $* * * p<0.01, * * p<0.05, * p<0.1$. Columns (1)-(6) of this table report the regression results when the Bivariate Probit, SUR, and Bivariate Tobit models are employed. These methods consider the possibility that decisions to buy term-life and whole-life are jointly determined. Since term-life and whole-life insurance are partial substitutes of each other, owning one type of life insurance may have a negative effect on the purchase of the other type of life insurance. For estimation, Stata codes, biprobit, sureg, and mvtobit are used. Columns (7)-(8) report the regression results on the number of insurance plans when we apply the Tobit model instead of the OLS model. The fact that the number of term-life insurance is significantly negatively associated with loss aversion does not change. 
Table A.12: Robustness Check 6: An Indicator Variable for Loss Aversion is Used (Age $\geq 60)$

\begin{tabular}{|c|c|c|c|c|c|c|}
\hline \multirow[b]{2}{*}{ VARIABLES } & \multicolumn{3}{|c|}{ Term-Life Insurance } & \multicolumn{3}{|c|}{ Whole-Life Insurance } \\
\hline & $\begin{array}{l}\text { (1) Probit } \\
\text { own_term }\end{array}$ & $\begin{array}{l}\text { (2) OLS } \\
\text { num_term }\end{array}$ & $\begin{array}{c}\text { (3) Tobit } \\
\text { log_amt_term }\end{array}$ & $\begin{array}{l}\text { (4) Probit } \\
\text { own_whole }\end{array}$ & $\begin{array}{l}\text { (5) OLS } \\
\text { num_whole }\end{array}$ & $\begin{array}{c}\text { (6) Tobit } \\
\text { log_amt_whole }\end{array}$ \\
\hline \multirow[t]{2}{*}{ i_lossaver } & $-0.168^{*}$ & $-0.111^{* *}$ & $-2.271^{* *}$ & 0.0643 & 0.0348 & -0.538 \\
\hline & $(0.0904)$ & $(0.0535)$ & $(0.986)$ & (0.0953) & $(0.0445)$ & $(2.144)$ \\
\hline \multirow[t]{2}{*}{ will } & 0.0477 & 0.0310 & 0.364 & $0.216^{* *}$ & $0.0896^{* *}$ & $5.748^{* *}$ \\
\hline & $(0.0950)$ & $(0.0578)$ & $(1.070)$ & $(0.0993)$ & $(0.0448)$ & (2.306) \\
\hline \multirow[t]{2}{*}{ log_income } & 0.0173 & 0.0231 & 0.105 & 0.0251 & 0.0188 & 0.526 \\
\hline & $(0.0367)$ & $(0.0203)$ & $(0.414)$ & $(0.0334)$ & $(0.0132)$ & $(0.825)$ \\
\hline \multirow[t]{2}{*}{ log_networth } & $0.0376^{* * *}$ & $0.0150^{* *}$ & $0.387^{* *}$ & 0.00810 & 0.00461 & 0.312 \\
\hline & $(0.0133)$ & $(0.00619)$ & $(0.158)$ & $(0.0130)$ & $(0.00484)$ & $(0.307)$ \\
\hline \multirow[t]{2}{*}{ female } & -0.113 & $-0.0860^{*}$ & -0.951 & $-0.212^{* *}$ & $-0.140^{* * *}$ & $-7.117^{* * *}$ \\
\hline & $(0.0854)$ & $(0.0508)$ & $(0.972)$ & $(0.0873)$ & $(0.0430)$ & (1.858) \\
\hline \multirow[t]{2}{*}{ married } & -0.0389 & -0.00168 & 0.190 & 0.0105 & 0.00935 & 0.0150 \\
\hline & $(0.0967)$ & $(0.0571)$ & (1.108) & $(0.1000)$ & $(0.0473)$ & (2.249) \\
\hline \multirow[t]{2}{*}{ age } & -0.0560 & -0.0239 & -0.708 & $0.144^{*}$ & 0.0560 & 3.341 \\
\hline & $(0.0764)$ & $(0.0412)$ & $(0.888)$ & $(0.0875)$ & $(0.0386)$ & (2.174) \\
\hline \multirow[t]{2}{*}{ age_sq } & 0.000297 & 0.000123 & 0.00326 & $-0.00100^{*}$ & -0.000375 & -0.0232 \\
\hline & $(0.000513)$ & $(0.000272)$ & $(0.00600)$ & $(0.000590)$ & (0.000260) & $(0.0147)$ \\
\hline \multirow[t]{2}{*}{ edu } & $0.0440^{* * *}$ & $0.0120^{*}$ & $0.553^{* * *}$ & 0.00660 & 0.00297 & 0.138 \\
\hline & $(0.0144)$ & $(0.00703)$ & $(0.166)$ & $(0.0153)$ & $(0.00711)$ & $(0.365)$ \\
\hline \multirow[t]{2}{*}{ kids } & 0.00287 & -0.00956 & 0.0409 & 0.0242 & 0.00403 & 0.0145 \\
\hline & (0.0199) & $(0.0102)$ & $(0.227)$ & $(0.0204)$ & $(0.00928)$ & $(0.435)$ \\
\hline \multirow[t]{2}{*}{ employed } & $0.216^{* *}$ & $0.144^{* *}$ & $2.664^{* *}$ & 0.115 & 0.0282 & 3.585 \\
\hline & $(0.108)$ & $(0.0664)$ & $(1.171)$ & $(0.115)$ & $(0.0516)$ & $(2.449)$ \\
\hline \multirow[t]{2}{*}{ Constant } & 1.093 & 1.121 & 17.93 & $-6.358^{* *}$ & -2.012 & $-150.7^{*}$ \\
\hline & (2.844) & (1.539) & (33.01) & (3.239) & $(1.414)$ & (79.03) \\
\hline Observations & 1,042 & 1,041 & 978 & 1,042 & 1,039 & 854 \\
\hline R-squared & & 0.048 & & & 0.028 & \\
\hline
\end{tabular}

Notes: Robust standard errors in parentheses. *** $p<0.01, * * p<0.05, * p<0.1$. This table reports the regression results when an indicator variable is used for high loss-aversion instead of using a continuous measure for loss aversion. The indicator variable (i_lossaver) takes the value of one if the person's loss aversion is equal to five and zero otherwise. 
Table A.13: Robustness Check 7: Health Status is Controlled for (Age $\geq 60$ )

\begin{tabular}{|c|c|c|c|c|c|c|}
\hline \multirow[b]{2}{*}{ VARIABLES } & \multicolumn{3}{|c|}{ Term-Life Insurance } & \multicolumn{3}{|c|}{ Whole-Life Insurance } \\
\hline & $\begin{array}{l}\text { (1) Probit } \\
\text { own_term }\end{array}$ & $\begin{array}{l}\text { (2) OLS } \\
\text { num_term }\end{array}$ & $\begin{array}{c}\text { (3) Tobit } \\
\text { log_amt_term }\end{array}$ & $\begin{array}{l}\text { (4) Probit } \\
\text { own_whole }\end{array}$ & $\begin{array}{l}\text { (5) OLS } \\
\text { num_whole }\end{array}$ & $\begin{array}{c}\text { (6) Tobit } \\
\text { log_amt_whole }\end{array}$ \\
\hline \multirow[t]{2}{*}{ lossavers } & $-0.0970^{*}$ & $-0.0665^{*}$ & $-1.329^{* *}$ & 0.0976 & 0.0449 & 0.827 \\
\hline & $(0.0584)$ & $(0.0354)$ & $(0.630)$ & $(0.0620)$ & $(0.0278)$ & $(1.386)$ \\
\hline \multirow[t]{2}{*}{ health_status } & -0.0364 & 0.00493 & -0.123 & 0.00534 & -0.00163 & -1.095 \\
\hline & $(0.0414)$ & $(0.0243)$ & $(0.480)$ & $(0.0420)$ & $(0.0215)$ & $(1.026)$ \\
\hline \multirow[t]{2}{*}{ will } & 0.0431 & 0.0308 & 0.336 & $0.211^{* *}$ & $0.0873^{*}$ & $5.381^{* *}$ \\
\hline & $(0.0950)$ & $(0.0577)$ & $(1.070)$ & $(0.0993)$ & $(0.0447)$ & $(2.286)$ \\
\hline \multirow[t]{2}{*}{ log_income } & 0.0152 & 0.0236 & 0.101 & 0.0278 & 0.0194 & 0.456 \\
\hline & $(0.0370)$ & $(0.0203)$ & $(0.417)$ & $(0.0336)$ & $(0.0131)$ & $(0.808)$ \\
\hline \multirow[t]{2}{*}{ log_networth } & $0.0363^{* * *}$ & $0.0154^{* *}$ & $0.385^{* *}$ & 0.00630 & 0.00382 & 0.250 \\
\hline & $(0.0135)$ & $(0.00639)$ & $(0.160)$ & $(0.0132)$ & $(0.00493)$ & $(0.310)$ \\
\hline \multirow[t]{2}{*}{ female } & -0.118 & $-0.0859^{*}$ & -0.967 & $-0.221^{* *}$ & $-0.144^{* * *}$ & $-7.296^{* * *}$ \\
\hline & $(0.0856)$ & $(0.0513)$ & (0.973) & $(0.0877)$ & $(0.0431)$ & $(1.857)$ \\
\hline \multirow[t]{2}{*}{ married } & -0.0395 & -0.00282 & 0.176 & 0.00987 & 0.00956 & -0.0361 \\
\hline & $(0.0968)$ & $(0.0571)$ & $(1.107)$ & $(0.100)$ & $(0.0475)$ & $(2.265)$ \\
\hline \multirow[t]{2}{*}{ age } & -0.0612 & -0.0244 & -0.733 & $0.151^{*}$ & 0.0580 & 3.205 \\
\hline & $(0.0762)$ & $(0.0416)$ & $(0.888)$ & $(0.0876)$ & $(0.0382)$ & $(2.155)$ \\
\hline \multirow[t]{2}{*}{ age_sq } & 0.000329 & 0.000125 & 0.00340 & $-0.00104^{*}$ & -0.000388 & -0.0223 \\
\hline & $(0.000511)$ & $(0.000275)$ & $(0.00600)$ & $(0.000590)$ & $(0.000257)$ & $(0.0146)$ \\
\hline \multirow[t]{2}{*}{ edu } & $0.0417^{* * *}$ & $0.0127^{*}$ & $0.548^{* * *}$ & 0.00662 & 0.00267 & 0.0501 \\
\hline & $(0.0146)$ & (0.00709) & $(0.169)$ & $(0.0156)$ & $(0.00724)$ & $(0.370)$ \\
\hline \multirow[t]{2}{*}{ kids } & 0.00240 & -0.00959 & 0.0373 & 0.0241 & 0.00404 & -0.00657 \\
\hline & $(0.0199)$ & $(0.0102)$ & $(0.227)$ & $(0.0205)$ & $(0.00931)$ & $(0.435)$ \\
\hline \multirow[t]{2}{*}{ employed } & $0.198^{*}$ & $0.146^{* *}$ & $2.600^{* *}$ & 0.123 & 0.0293 & 3.255 \\
\hline & $(0.110)$ & $(0.0670)$ & $(1.192)$ & $(0.116)$ & $(0.0519)$ & $(2.438)$ \\
\hline \multirow[t]{2}{*}{ Constant } & 1.627 & 1.221 & 21.63 & $-6.854^{* *}$ & -2.173 & $-142.1^{*}$ \\
\hline & $(2.866)$ & $(1.588)$ & (33.28) & $(3.251)$ & $(1.375)$ & (77.82) \\
\hline Observations & 1,040 & 1,039 & 976 & 1,040 & 1,037 & 853 \\
\hline R-squared & & 0.047 & & & 0.029 & \\
\hline
\end{tabular}

Notes: Robust standard errors in parentheses. *** $p<0.01, * * p<0.05, * p<0.1$. This table reports the regression results when self-reported health status is controlled for. The variable health_status takes 1 (excellent), 2, 3, 4, 5 (poor). 
Table A.14: Robustness Check (Wealth) 2: Samples are Restricted to Those Aged 65-70

\begin{tabular}{|c|c|c|c|c|c|}
\hline VARIABLES & $\begin{array}{c}(1) \\
\log _{-} \text {Stock }\end{array}$ & $\begin{array}{c}\text { (2) } \\
\text { log_House }\end{array}$ & $\begin{array}{c}\text { (3) } \\
\text { log_Nonrisky }\end{array}$ & $\begin{array}{c}(4) \\
\text { log_NetFinWorth }\end{array}$ & $\begin{array}{c}\text { (5) } \\
\text { log_NetWorth }\end{array}$ \\
\hline \multirow[t]{2}{*}{ lossavers } & $-3.226^{* *}$ & 0.0710 & -0.0504 & -0.0707 & $0.508^{*}$ \\
\hline & $(1.400)$ & $(0.448)$ & $(0.379)$ & $(0.579)$ & $(0.306)$ \\
\hline \multirow[t]{2}{*}{ log_income } & -0.188 & 0.181 & 0.437 & 0.819 & 0.0312 \\
\hline & (1.085) & $(0.358)$ & $(0.295)$ & $(0.543)$ & $(0.190)$ \\
\hline \multirow[t]{2}{*}{ edu } & $1.247^{* *}$ & 0.117 & 0.197 & 0.351 & 0.157 \\
\hline & (0.621) & $(0.209)$ & $(0.163)$ & $(0.252)$ & $(0.113)$ \\
\hline \multirow[t]{2}{*}{ will } & $9.557^{* * *}$ & $2.819^{* * *}$ & $2.754^{* * *}$ & $4.092^{* * *}$ & $1.484^{* * *}$ \\
\hline & (2.435) & $(0.785)$ & $(0.728)$ & $(1.040)$ & $(0.448)$ \\
\hline \multirow[t]{2}{*}{ female } & 1.333 & $1.380^{*}$ & 0.752 & 0.679 & 0.125 \\
\hline & (2.364) & $(0.752)$ & $(0.667)$ & $(0.911)$ & $(0.414)$ \\
\hline \multirow[t]{2}{*}{ married } & 4.615 & $2.220^{* *}$ & 0.736 & 1.417 & 0.888 \\
\hline & (3.487) & $(0.981)$ & $(0.815)$ & $(1.301)$ & $(0.583)$ \\
\hline \multirow[t]{2}{*}{ kids } & $-1.826^{* * *}$ & $0.317^{*}$ & -0.255 & -0.320 & 0.0918 \\
\hline & $(0.683)$ & $(0.188)$ & $(0.198)$ & $(0.272)$ & $(0.104)$ \\
\hline \multirow[t]{2}{*}{ employed } & $4.619^{*}$ & -0.455 & 0.225 & 0.385 & $0.980^{*}$ \\
\hline & (2.671) & $(0.876)$ & (0.693) & $(1.106)$ & $(0.547)$ \\
\hline \multirow[t]{2}{*}{ selfemp } & $-7.748^{* *}$ & 1.733 & -0.133 & 0.502 & -0.571 \\
\hline & (3.682) & $(1.176)$ & $(0.968)$ & $(1.121)$ & $(0.804)$ \\
\hline \multirow[t]{2}{*}{ own_house } & 4.310 & & $2.408^{* *}$ & $4.742^{* * *}$ & $6.206^{* * *}$ \\
\hline & $(4.974)$ & & $(1.094)$ & $(1.749)$ & $(0.961)$ \\
\hline \multirow[t]{2}{*}{ i_hispanic } & & -0.0624 & $-3.232^{*}$ & -2.887 & 0.314 \\
\hline & & $(1.427)$ & $(1.670)$ & (2.060) & $(0.761)$ \\
\hline \multirow[t]{2}{*}{ Constant } & $-35.39^{* *}$ & -0.720 & -4.493 & $-14.80^{* *}$ & 0.426 \\
\hline & $(14.88)$ & (4.630) & (3.972) & (6.824) & $(2.554)$ \\
\hline occupation_dummies1 & 0 & 0 & 0 & 0 & 0 \\
\hline Observations & 224 & 224 & 224 & 224 & 224 \\
\hline
\end{tabular}

Notes: Robust standard errors in parentheses. $* * * p<0.01, * * p<0.05, * p<0.1$. This table reports the regression results when the sample is restricted to those in the same life-cycle stage, those aged 65-70 in particular. occupation_dummies1 represents 17 occupation dummy variables, which is based on the occupation code for job with longest reported tenure (RAND HRS code: R11JLOCC). 
Table A.15: Robustness Check (Wealth) 3: Indicator Variables for Loss Aversion are Used (Age $\geq 65$ )

\begin{tabular}{|c|c|c|c|c|c|c|c|c|c|c|}
\hline & $(1)$ & (2) & (3) & (4) & (5) & (6) & (7) & (8) & (9) & $(10)$ \\
\hline VARIABLES & log_Stock ll & log_House & log_Nonrisky & NetFinWort & og_NetWorth & log_Stock & log_House & log_Nonrisky & NetFinWort & g_NetWorth \\
\hline i_lossaver & $-2.648^{* *}$ & 0.346 & 0.523 & 0.248 & 0.340 & & & & & \\
\hline & $(1.323)$ & $(0.460)$ & $(0.355)$ & $(0.445)$ & $(0.212)$ & & & & & \\
\hline i_lossaver2 & & & & & & $-4.083^{* *}$ & 0.814 & $1.074^{* *}$ & 0.627 & $0.779^{* *}$ \\
\hline & & & & & & $(1.846)$ & $(0.661)$ & $(0.515)$ & $(0.652)$ & $(0.348)$ \\
\hline log_income & $3.772^{* * *}$ & 0.308 & $0.810^{* * *}$ & $1.036^{* * *}$ & $0.229^{* *}$ & $3.809^{* * *}$ & 0.307 & $0.809^{* * *}$ & $1.035^{* * *}$ & $0.228^{* *}$ \\
\hline & $(0.830)$ & $(0.215)$ & $(0.234)$ & $(0.306)$ & $(0.0996)$ & $(0.826)$ & $(0.213)$ & $(0.232)$ & $(0.305)$ & $(0.0987)$ \\
\hline edu & $1.111^{* * *}$ & $0.156^{*}$ & $0.281^{* * *}$ & $0.369^{* * *}$ & $0.145^{* * *}$ & $1.102^{* * *}$ & $0.156^{*}$ & $0.282^{* * *}$ & $0.370^{* * *}$ & $0.145^{* * *}$ \\
\hline & $(0.266)$ & $(0.0847)$ & $(0.0662)$ & $(0.0859)$ & $(0.0372)$ & $(0.265)$ & $(0.0841)$ & $(0.0661)$ & $(0.0859)$ & $(0.0367)$ \\
\hline age & 3.044 & 0.564 & -0.303 & 0.515 & 0.0468 & 3.027 & 0.560 & -0.306 & 0.513 & 0.0448 \\
\hline & $(1.851)$ & $(0.604)$ & $(0.443)$ & $(0.539)$ & $(0.241)$ & $(1.849)$ & $(0.604)$ & $(0.442)$ & $(0.538)$ & $(0.239)$ \\
\hline age_sq & -0.0195 & -0.00411 & 0.00224 & -0.00268 & -0.000196 & -0.0194 & -0.00408 & 0.00226 & -0.00267 & -0.000181 \\
\hline & $(0.0120)$ & $(0.00393)$ & $(0.00285)$ & $(0.00346)$ & $(0.00155)$ & $(0.0119)$ & $(0.00393)$ & $(0.00284)$ & $(0.00345)$ & $(0.00154)$ \\
\hline will & $10.00^{* * *}$ & $2.281^{* * *}$ & $2.364^{* * *}$ & $3.567^{* * *}$ & $1.685^{* * *}$ & $9.966^{* * *}$ & $2.271^{* * *}$ & $2.358^{* * *}$ & $3.562^{* * *}$ & $1.678^{* * *}$ \\
\hline & (1.579) & $(0.477)$ & $(0.363)$ & $(0.483)$ & $(0.206)$ & $(1.591)$ & $(0.475)$ & $(0.361)$ & $(0.482)$ & $(0.205)$ \\
\hline female & $2.789^{* *}$ & 0.440 & 0.445 & 0.624 & 0.152 & $2.810^{* *}$ & 0.447 & 0.454 & 0.627 & 0.159 \\
\hline & $(1.297)$ & $(0.437)$ & $(0.334)$ & $(0.440)$ & $(0.192)$ & $(1.295)$ & $(0.435)$ & $(0.334)$ & $(0.441)$ & $(0.191)$ \\
\hline married & $4.636^{* * *}$ & $3.156^{* * *}$ & $0.834^{* *}$ & $1.389^{* * *}$ & $0.795^{* * *}$ & $4.415^{* * *}$ & $3.194^{* * *}$ & $0.889^{* *}$ & $1.419^{* * *}$ & $0.835^{* * *}$ \\
\hline & (1.510) & $(0.486)$ & $(0.363)$ & $(0.489)$ & $(0.207)$ & $(1.504)$ & $(0.486)$ & $(0.361)$ & $(0.489)$ & $(0.206)$ \\
\hline kids & $-0.998^{* * *}$ & 0.0374 & -0.0959 & -0.124 & -0.0171 & $-0.967^{* * *}$ & 0.0390 & -0.0939 & -0.123 & -0.0155 \\
\hline & $(0.332)$ & $(0.0924)$ & $(0.0727)$ & $(0.0951)$ & $(0.0445)$ & $(0.329)$ & $(0.0922)$ & $(0.0727)$ & $(0.0952)$ & $(0.0444)$ \\
\hline employed & -2.148 & -0.0461 & -0.419 & -0.421 & $0.513^{*}$ & -2.130 & -0.0493 & -0.418 & -0.421 & $0.511^{*}$ \\
\hline & $(2.020)$ & $(0.617)$ & $(0.471)$ & $(0.653)$ & $(0.284)$ & $(2.001)$ & $(0.616)$ & $(0.472)$ & $(0.654)$ & $(0.285)$ \\
\hline i_hispanic & $-16.92^{* * *}$ & -0.751 & $-2.640^{* * *}$ & $-2.745^{* * *}$ & -0.422 & $-16.21^{* * *}$ & -0.775 & $-2.678^{* * *}$ & $-2.768^{* * *}$ & -0.443 \\
\hline & $(5.241)$ & $(0.937)$ & $(0.816)$ & $(0.976)$ & $(0.416)$ & $(5.085)$ & $(0.933)$ & $(0.816)$ & $(0.977)$ & $(0.407)$ \\
\hline own_home & 1.899 & & $1.102^{* * *}$ & $1.896 * *$ & $5.319^{* * *}$ & 1.907 & & $1.083^{* * *}$ & $1.886^{* * *}$ & $5.302^{* * *}$ \\
\hline & $(1.789)$ & & $(0.414)$ & $(0.542)$ & $(0.382)$ & $(1.788)$ & & $(0.414)$ & $(0.543)$ & $(0.379)$ \\
\hline $\begin{array}{l}\text { occupation_ } \\
\text { dummies }\end{array}$ & 0 & 0 & 0 & 0 & 0 & 0 & 0 & 0 & 0 & 0 \\
\hline Constant & $-186.1^{* * *}$ & -20.20 & 2.082 & $-36.53^{*}$ & -1.512 & $-183.8^{* *}$ & -20.52 & 1.585 & $-36.85^{*}$ & -1.892 \\
\hline & (71.24) & $(23.21)$ & $(17.21)$ & (20.96) & $(9.275)$ & (71.32) & $(23.21)$ & $(17.15)$ & (20.94) & $(9.191)$ \\
\hline Observations & 829 & 829 & 829 & 829 & 829 & 829 & 829 & 829 & 829 & 829 \\
\hline
\end{tabular}

Notes: Robust standard errors in parentheses. $* * * p<0.01, * * p<0.05, * p<0.1$. This table reports the regression results when indicator variables for loss aversion (i_lossaver $(\lambda=3.15)$; i_lossaver2 $(\lambda \geq 2.15))$ are used as explanatory variables. 
Table A.16: Robustness Check (Wealth) 4: Risk Aversion Measure is Controlled for (Age $\geq 65)$

\begin{tabular}{|c|c|c|c|c|c|c|c|c|c|c|}
\hline & $(1)$ & (2) & (3) & (4) & (5) & (6) & (7) & (8) & (9) & $(10)$ \\
\hline VARIABLES & log_Stock & log_House & log_Nonrisky & log_NetFinWorth & log_NetWorth & log_Stock & log_House & log_Nonrisky & log_NeiFinWorth & log_NetWorth \\
\hline \multirow[t]{2}{*}{ lossavers } & $-4.510^{* * *}$ & -0.412 & -0.187 & -0.284 & 0.287 & & & & & \\
\hline & $(1.498)$ & $(0.436)$ & $(0.428)$ & $(0.622)$ & $(0.343)$ & & & & & \\
\hline \multirow[t]{2}{*}{ riskavers } & 0.533 & -0.0150 & 0.205 & 0.303 & 0.0232 & -0.388 & -0.0365 & 0.0520 & 0.0191 & -0.0316 \\
\hline & $(0.714)$ & $(0.253)$ & $(0.239)$ & $(0.304)$ & $(0.171)$ & $(0.244)$ & $(0.0777)$ & $(0.0618)$ & $(0.0893)$ & $(0.0407)$ \\
\hline \multirow[t]{2}{*}{ log_income } & 0.940 & $0.785^{*}$ & 0.593 & 0.609 & 0.222 & $2.303^{* * *}$ & $0.509^{* * *}$ & $0.561^{* * *}$ & $0.823^{* * *}$ & $0.347^{* * *}$ \\
\hline & $(1.402)$ & $(0.412)$ & $(0.438)$ & $(0.622)$ & $(0.269)$ & $(0.493)$ & $(0.125)$ & $(0.104)$ & $(0.173)$ & $(0.0843)$ \\
\hline \multirow[t]{2}{*}{ edu } & 0.611 & 0.226 & $0.264^{*}$ & $0.504^{* *}$ & 0.0983 & $1.237^{* * *}$ & $0.113^{* *}$ & $0.375^{* * *}$ & $0.497^{* * *}$ & $0.158^{* * *}$ \\
\hline & $(0.481)$ & $(0.156)$ & $(0.144)$ & $(0.195)$ & $(0.0929)$ & $(0.186)$ & $(0.0515)$ & $(0.0427)$ & $(0.0619)$ & $(0.0286)$ \\
\hline \multirow[t]{2}{*}{ age } & $-90.10^{* *}$ & -4.752 & 0.147 & 6.341 & -4.080 & 3.728 & -0.519 & 1.223 & 4.347 & 2.144 \\
\hline & $(44.36)$ & $(14.61)$ & $(14.08)$ & $(19.36)$ & $(10.31)$ & (8.611) & $(2.313)$ & (2.198) & (3.345) & $(1.376)$ \\
\hline \multirow[t]{2}{*}{ age_sq } & $0.675^{* *}$ & 0.0360 & 0.000567 & -0.0422 & 0.0310 & -0.0267 & 0.00385 & -0.00901 & -0.0313 & -0.0154 \\
\hline & $(0.328)$ & $(0.108)$ & $(0.104)$ & $(0.143)$ & $(0.0761)$ & $(0.0632)$ & $(0.0170)$ & $(0.0162)$ & $(0.0246)$ & $(0.0101)$ \\
\hline \multirow[t]{2}{*}{ will } & $10.68^{* * *}$ & $2.266^{* * *}$ & $2.727^{* * *}$ & $4.323^{* * *}$ & $1.897^{* * *}$ & $7.623^{* * *}$ & $2.374^{* * *}$ & $1.433^{* * *}$ & $2.580^{* * *}$ & $0.994^{* * *}$ \\
\hline & $(2.414)$ & $(0.712)$ & $(0.710)$ & $(0.990)$ & $(0.434)$ & $(0.837)$ & $(0.244)$ & $(0.194)$ & $(0.291)$ & $(0.137)$ \\
\hline \multirow[t]{2}{*}{ female } & 0.450 & 0.725 & 0.168 & 0.612 & 0.525 & 0.670 & 0.268 & -0.115 & 0.0332 & -0.0959 \\
\hline & $(2.204)$ & $(0.714)$ & $(0.705)$ & $(1.007)$ & $(0.422)$ & $(0.823)$ & $(0.249)$ & $(0.195)$ & $(0.296)$ & $(0.142)$ \\
\hline \multirow[t]{2}{*}{ married } & 3.766 & $1.891^{*}$ & 1.048 & 2.022 & 0.640 & $2.092^{* *}$ & $2.889^{* * *}$ & $0.681^{* * *}$ & $0.972^{* * *}$ & $0.802^{* * *}$ \\
\hline & $(3.234)$ & $(0.965)$ & $(0.841)$ & $(1.281)$ & $(0.562)$ & $(0.917)$ & $(0.282)$ & $(0.218)$ & $(0.326)$ & $(0.153)$ \\
\hline \multirow[t]{2}{*}{ kids } & $-1.847^{* *}$ & $0.442^{* *}$ & -0.176 & -0.143 & 0.0748 & $-1.107^{* * *}$ & -0.0890 & $-0.264^{* * *}$ & $-0.344^{* * *}$ & $-0.132^{* * *}$ \\
\hline & $(0.720)$ & $(0.190)$ & $(0.209)$ & $(0.289)$ & $(0.122)$ & $(0.241)$ & $(0.0637)$ & $(0.0510)$ & $(0.0742)$ & $(0.0366)$ \\
\hline \multirow[t]{2}{*}{ employed } & 2.186 & 0.0290 & -0.0511 & -0.214 & $0.917^{*}$ & -0.797 & -0.265 & -0.174 & $-0.722^{* *}$ & -0.0932 \\
\hline & $(2.721)$ & $(0.834)$ & $(0.728)$ & $(0.995)$ & $(0.486)$ & $(0.894)$ & $(0.268)$ & $(0.207)$ & $(0.320)$ & $(0.154)$ \\
\hline \multirow[t]{2}{*}{ i_hispanic } & -64.20 & $2.722^{* * *}$ & -2.102 & -2.335 & $1.320^{* * *}$ & $-5.864^{* *}$ & 0.619 & $-1.708^{* * *}$ & -1.036 & 0.363 \\
\hline & (0) & $(1.024)$ & $(1.687)$ & $(2.030)$ & $(0.476)$ & (2.318) & $(0.513)$ & $(0.484)$ & $(0.632)$ & $(0.254)$ \\
\hline \multirow[t]{2}{*}{ own_house } & 6.546 & & 1.273 & $3.295^{*}$ & $5.648^{* * *}$ & $8.585^{* * *}$ & & $1.745^{* * *}$ & $2.909^{* * *}$ & $5.284^{* * *}$ \\
\hline & $(4.362)$ & & $(1.349)$ & $(1.788)$ & $(1.125)$ & $(1.693)$ & & $(0.301)$ & $(0.460)$ & $(0.289)$ \\
\hline \multirow[t]{2}{*}{ Constant } & $2,965^{* *}$ & 152.7 & -18.60 & -250.9 & 133.5 & -188.6 & 16.29 & -46.86 & -163.4 & -74.36 \\
\hline & $(1,502)$ & $(493.8)$ & $(475.5)$ & $(654.5)$ & $(348.2)$ & (292.9) & (78.70) & $(74.65)$ & $(113.6)$ & $(46.72)$ \\
\hline $\begin{array}{l}\text { Occupation } \\
\text { Dummies }\end{array}$ & 0 & 0 & 0 & 0 & 0 & 0 & 0 & 0 & 0 & 0 \\
\hline Observations & 197 & 197 & 197 & 197 & 197 & 2,215 & 2,215 & 2,215 & 2,215 & 2,215 \\
\hline
\end{tabular}

Notes: Robust standard errors in parentheses. $* * * p<0.01, * * p<0.05, * p<0.1$. This table displays the regression results when a risk aversion measure (riskavers) is controlled for. The variable riskavers is measured by the status-quo-bias-free lifetime income gamble questions by Barsky et al. (1997) in the HRS. The variable takes the values of $1,2, \cdots$,or 6 . See Table A.1 for details. 
Table A. 17: Robustness Check (Wealth) 5: Asset-specific Share of Net Worth is Used as a Dependent Variable, Tobit Regression Results (Age $\geq 65$ )

\begin{tabular}{|c|c|c|c|c|c|c|}
\hline VARIABLES & $\begin{array}{c}\text { (1) } \\
\text { share_Stock }\end{array}$ & share_House & share_Nonrisky & $\begin{array}{c}(4) \\
\text { share_Stock }\end{array}$ & $\begin{array}{c}(5) \\
\text { share_House }\end{array}$ & share_Nonrisky \\
\hline \multirow[t]{2}{*}{ lossavers } & $-5.997^{*}$ & 0.0834 & 1.901 & $-5.881^{*}$ & $0.718^{* *}$ & 1.397 \\
\hline & (3.062) & (2.304) & (1.578) & (3.036) & $(0.288)$ & (1.403) \\
\hline \multirow[t]{2}{*}{ log_income } & & & & $9.849^{* * *}$ & $-6.026^{* * *}$ & $3.158^{* * *}$ \\
\hline & & & & (2.718) & $(0.0842)$ & $(0.879)$ \\
\hline \multirow[t]{2}{*}{ edu } & & & & $3.488^{* * *}$ & $-1.865^{* * *}$ & 0.274 \\
\hline & & & & (0.922) & $(0.0646)$ & $(0.369)$ \\
\hline \multirow[t]{2}{*}{ age } & & & & $11.91^{*}$ & $-4.347^{* * *}$ & $-7.993^{* *}$ \\
\hline & & & & $(6.787)$ & $(0.0117)$ & (3.402) \\
\hline \multirow[t]{2}{*}{ age_sq } & & & & $-0.0760^{*}$ & $0.0311^{* * *}$ & $0.0559^{* *}$ \\
\hline & & & & $(0.0440)$ & $(0.000147)$ & (0.0223) \\
\hline \multirow[t]{2}{*}{ will } & & & & $33.43^{* * *}$ & $-16.17^{* * *}$ & $4.146^{*}$ \\
\hline & & & & (5.771) & $(0.730)$ & $(2.123)$ \\
\hline \multirow[t]{2}{*}{ female } & & & & 5.514 & 0.449 & 3.125 \\
\hline & & & & $(4.508)$ & (0.680) & $(2.067)$ \\
\hline \multirow[t]{2}{*}{ married } & & & & $11.20^{* *}$ & $-5.866^{* * *}$ & $-3.968^{*}$ \\
\hline & & & & (5.395) & $(0.703)$ & $(2.143)$ \\
\hline \multirow[t]{2}{*}{ kids } & & & & $-3.290^{* * *}$ & $0.846^{* * *}$ & -0.397 \\
\hline & & & & (1.173) & $(0.156)$ & $(0.438)$ \\
\hline \multirow[t]{2}{*}{ employed } & & & & -2.918 & $-2.273^{* * *}$ & -4.060 \\
\hline & & & & $(7.467)$ & $(0.532)$ & $(2.518)$ \\
\hline \multirow[t]{2}{*}{ i_hispanic } & & & & $-50.67^{* * *}$ & $9.916^{* * *}$ & -6.391 \\
\hline & & & & (17.69) & $(0.542)$ & $(5.011)$ \\
\hline \multirow[t]{2}{*}{ own_house } & & & & -8.417 & $276.1^{* * *}$ & $-35.48^{* * *}$ \\
\hline & & & & (7.888) & $(0.887)$ & $(4.133)$ \\
\hline \multirow[t]{2}{*}{ Constant } & -13.29 & $41.76^{* * *}$ & $9.074^{* *}$ & $-633.0^{* *}$ & $21.49^{* * *}$ & $284.1^{* *}$ \\
\hline & (8.833) & $(6.636)$ & $(4.518)$ & $(261.4)$ & $(0.887)$ & (128.9) \\
\hline Observations & 777 & 777 & 777 & 769 & 769 & 769 \\
\hline
\end{tabular}

Notes: Robust standard errors in parentheses. $* * * p<0.01, * * p<0.05, * p<0.1$. This table displays the Tobit regression results when the dependent variable is share by asset type (\%). For example, the dependent variable of the first column is (Stock / Net Worth)*100. 


\section{Appendix B: Proofs of [A4]}

Proof) An increase in $\hat{d}_{t}$ increases the demand for term-life insurance:

The quotient rule of derivatives is applied in equation (2.25).

$$
\begin{aligned}
& \frac{\partial a_{t+1}(s 1)^{*}}{\partial \hat{d}_{t}}=\frac{e_{t}+q_{t} e_{t+1}(s 1)+\frac{1-q_{t} R_{t+1}}{R_{t+1}} e_{t+1}(s 2)}{\left[1+q_{t}\left(\frac{\beta \pi_{1}}{q_{t}} \hat{d}_{t}\right)^{1 / \gamma}+\left(\frac{1-q_{t} R_{t+1}}{R_{t+1}}\right)^{1-1 / \gamma}\left(\beta \pi_{2}\right)^{1 / \gamma} \cdot\left\{1+\widehat{d_{t+1}}{ }^{1 / \gamma}\right\}\right]^{2}} * \\
& \left\langle\left[ 1 / \gamma\left(\frac{\beta \pi_{1}}{q_{t}} \widehat{d_{t}}\right)^{1 / \gamma^{-1}} * \frac{\beta \pi_{1}}{q_{t}} *\left[1+q_{t}\left(\frac{\beta \pi_{1}}{q_{t}} \widehat{d_{t}}\right)^{1 / \gamma}+\left(\frac{1-q_{t} R_{t+1}}{R_{t+1}}\right)^{1-1 / \gamma}\left(\beta \pi_{2}\right)^{1 / \gamma} \cdot\left\{1+\widehat{d_{t+1}}{ }^{1 / \gamma}\right\}\right]-\right.\right. \\
& {\left[\left(\frac{\beta \pi_{1}}{q_{t}} \widehat{d}_{t}\right)^{1 / \gamma}-\left(\frac{R_{t+1}}{1-q_{t} R_{t+1}} \beta \pi_{2}\right)^{1 / \gamma} \cdot\left\{1+\widehat{d_{t+1}}{ }^{1 / \gamma}\right\}\right] * 1 / \gamma^{*} q_{t}\left(\frac{\beta \pi_{1}}{q_{t}} \widehat{d_{t}}\right)^{\left.1 / \gamma^{-1} * \frac{\beta \pi_{1}}{q_{t}}\right\rangle}}
\end{aligned}
$$

The terms in $\langle>$ follows:

$$
\begin{aligned}
& 1 / \gamma\left(\frac{\beta \pi_{1}}{q_{t}} \widehat{d}_{t}\right)^{1 / \gamma^{-1}} * \frac{\beta \pi_{1}}{q_{t}} *\left[1+q_{t}\left(\frac{\beta \pi_{1}}{q_{t}} \widehat{d_{t}}\right)^{1 / \gamma}+\left(\frac{1-q_{t} R_{t+1}}{R_{t+1}}\right)^{1-1 / \gamma}\left(\beta \pi_{2}\right)^{1 / \gamma} \cdot\left\{1+\widehat{d_{t+1}} 1 / \gamma\right\}\right]+\left[-\left(\frac{\beta \pi_{1}}{q_{t}} \widehat{d_{t}}\right)^{1 / \gamma}+\right. \\
& \left.\left(\frac{R_{t+1}}{1-q_{t} R_{t+1}} \beta \pi_{2}\right)^{1 / \gamma} \cdot\left\{1+\widehat{d_{t+1}}{ }^{1 / \gamma}\right\}\right]^{*} 1 / \gamma^{*} q_{t}\left(\frac{\beta \pi_{1}}{q_{t}} \widehat{d_{t}}\right)^{\left.1 / \gamma^{-1} * \frac{\beta \pi_{1}}{q_{t}}\right]} \\
& =1 / \gamma\left(\frac{\beta \pi_{1}}{q_{t}} \widehat{d_{t}}\right)^{1 / \gamma^{-1}} * \frac{\beta \pi_{1}}{q_{t}}\left[1+\left(q_{t}-1\right)\left(\frac{\beta \pi_{1}}{q_{t}} \widehat{d_{t}}\right)^{1 / \gamma}+\left(\frac{1-q_{t} R_{t+1}}{R_{t+1}}\right)^{1-1 / \gamma}\left(\beta \pi_{2}\right)^{1 / \gamma} \cdot\left\{1+\widehat{d_{t+1}} 1 / \gamma\right\}+\right. \\
& \left(\frac{R_{t+1}}{1-q_{t} R_{t+1}} \beta \pi_{2}\right)^{1 / \gamma} \cdot\left\{1+\widehat{d}_{t+1}^{1 / \gamma}\right\}
\end{aligned}
$$

Note that everything is positive except for $\left(q_{t}-1\right)$. Since $\widehat{d}_{t} \leq 1, q_{t} \geq \beta \pi_{1}$ (equality holds at a fair premium), and $\gamma>0$ the term $\left(q_{t}-1\right)\left(\frac{\beta \pi_{1}}{q_{t}} \widehat{d}_{t}\right)^{1 / \gamma}$ is greater than negative one.

Thus $1+\left(q_{t}-1\right)\left(\frac{\beta \pi_{1}}{q_{t}} \hat{d}_{t}\right)^{1 / \gamma}$ is positive. Thus $\frac{\partial a_{t+1}(s 1)^{*}}{\partial \hat{d}_{t}}>0$.

Proof) An increase in $\hat{d}_{t}$ decreases the demand for saving:

The result (2.21) says that an increase in $\hat{d}_{t}$ decreases $C_{t}^{*}$. The result (2.26) says that this leads to a decrease in $b_{t+1}{ }^{*}$ 
Proof) An increase in $\widehat{d_{t+1}}$ decreases the optimal level of term-life insurance:

The result is obvious in the equations (2.21) and (2.25):

$\widehat{d_{t+1}} \uparrow \rightarrow C_{t}^{*} \downarrow$ and $\left[\left(\frac{\beta \pi_{1}}{q_{t}} \widehat{d}_{t}\right)^{1 / \gamma}-\left(\frac{R_{t+1}}{1-q_{t} R_{t+1}} \beta \pi_{2}\right)^{1 / \gamma} \cdot\left\{1+\widehat{d_{t+1}}{ }^{1 / \gamma}\right\}\right] \downarrow$

Proof) An increase in $\widehat{d_{t+1}}$ increases the optimal level of saving:

The quotient rule of derivatives is applied in equation (2.26).

$$
\begin{aligned}
& \frac{\partial b_{t+1}}{\partial \widetilde{d_{t+1}}}=\frac{e_{t}+q_{t} e_{t+1}(s 1)+\frac{1-q_{t} R_{t+1}}{R_{t+1}} e_{t+1}(s 2)}{\left[1+q_{t}\left(\frac{\beta \pi_{1}}{q_{t}} \widehat{d}_{t}\right)^{1 / \gamma}+\left(\frac{1-q_{t} R_{t+1}}{R_{t+1}}\right)^{1-1 / \gamma}\left(\beta \pi_{2}\right)^{1 / \gamma} \cdot\left\{1+\widetilde{d_{t+1}}{ }^{1 / \gamma}\right\}\right]^{2}} \cdot \frac{1}{R_{t+1}} \cdot\left(\frac{R_{t+1}}{1-q_{t} R_{t+1}} \beta \pi_{2}\right)^{1 / \gamma} . \\
& \left\langle 1 / \gamma \widehat{d_{t+1}}{ }^{1 / \gamma-1} \cdot\left[1+q_{t}\left(\frac{\beta \pi_{1}}{q_{t}} \widehat{d}_{t}\right)^{1 / \gamma}+\left(\frac{1-q_{t} R_{t+1}}{R_{t+1}}\right)^{1-1 / \gamma}\left(\beta \pi_{2}\right)^{1 / \gamma-1} \cdot\left\{1+\widehat{d_{t+1}}{ }^{1 / \gamma}\right\}\right]-\left(1+\widehat{d t+1}^{1 / \gamma}\right) .\right. \\
& \left\{\left(\frac{1-q_{t} R_{t+1}}{R_{t+1}}\right)^{1-1 / \gamma \cdot} \cdot\left(\beta \pi_{2}\right)^{1 / \gamma} \cdot 1 / \gamma \cdot \widehat{d_{t+1}}{ }^{1 / \gamma-1}\right.
\end{aligned}
$$

The terms in $\langle>$ follows:

$$
\left[1 / \gamma \cdot \widehat{d_{t+1}}{ }^{1 / \gamma-1} \cdot\left(\frac{1-q_{t} R_{t+1}}{R_{t+1}}\right)^{1-1 / \gamma} \cdot\left(1+\widehat{d_{t+1}} \widehat{1}^{1 / \gamma}\right)\right] \cdot\left\{1-\left(\beta \pi_{2}\right)^{1 / \gamma}\right\}+1 / \gamma \cdot \widehat{d_{t+1}}{ }^{1 / \gamma-1} \cdot\left(1+q_{t}\left(\frac{\beta \pi_{1}}{q_{t}} \hat{d}_{t}\right)^{1 / \gamma} .\right.
$$

Note that everything is positive except for $-\left(\beta \pi_{2}\right)^{1 / \gamma}$. Since $\beta \pi_{2} \leq 1$ and $\gamma>0$, the term $\left\{1-\left(\beta \pi_{2}\right)^{1 / \gamma}\right\}$ is positive. Thus $\frac{\partial b_{t+1}{ }^{*}}{\partial \widehat{d_{t+1}}}>0$. 


\section{$<$ Abstract in Korean> \\ 가계 자산선택의 행태경제학적 접근: 손실회피가 생명보험 가입과 저축에 미치는 영향}

황인도*

본고는 손실회피가 저축 및 보험 가입 의사결정에 미치는 영향을 분석하였다. 구체적으로 본고는 프로스펙트 이론(prospect theory)의 손실회피가 보험 수요를 낮추는 대신 저축 수요를 높이는 지 실증적으로 검증하였다. 프로스펙트 이론은 합리성이 부족한 소비자의 경우 정기보험 등 순수보장성 보험을 ‘손실'을 끼칠 수 있는 ‘위험한 투자'로 간주할 수 있음을 말해주고 있다. 따라서 손실에 민감한 개인은 정기보험에 가입하지 않고, 대신 예비적 저축을 늘려 불확실한 미래에 대비할 가능성이 있다.

본 연구는 미국 Health and Retirement Study (HRS)의 개인별 데이터를 이 용하여 상기 예측을 검증하였으며 이에 부합하는 결과를 얻었다. 손실회피도가 높은 개인은 정기보험 가입률이 낮고, 저축 기능이 있는 종신보험 가입률은 높 은 것으로 나타났다. 또한 손실회피도가 높은 개인은 다른 사람보다 높은 수준 의 부(wealth)를 보유하고 있는 것으로 나타났는데, 이는 다른 조건이 같다면 저 축(예비적 동기의 저축)을 더 많이 한다는 것을 시사한다.

핵심 주제어: 손실회피, 정기 보험, 종신 보험, 예비적 저축, 프로스펙트 이론 JEL Classification: D03, D14, G22

\footnotetext{
* 한국은행 경제연구원 금융통화연구실 부연구위원 (전화: 02-759-5362, E-mail: hid@bok.or.kr)
} 


\section{$\mathrm{BOK}$ 경제연구 발간목록}

한국은행 경제연구원에서는 Working Paper인 『BOK 경제연구』를 수시로 발간하고 있습니다. ${ }^{\circledR B O K}$ 경제연구』는 주요 경제 현상 및 정책 효과에 대한 직관적 설명 뿐 아니라 깊이 있는 이론 또는 실증 분석을 제공함으로써 엄밀한 논증에 초점을 두는 학술논문 형태의 연구이며 한국은행 직원 및 한국은행 연구용역사업의 연구 결과물이 수록되고 있습니다.

${ }^{『} \mathrm{BOK}$ 경제연구』는 한국은행 경제연구원 홈페이지(http://imer.bok.or.kr)에서 다운로드하여 보실 수 있습니다.

제2014-1 Network Indicators for Monitoring Intraday Liquidity in BOK-Wire+

2 중소기업에 대한 신용정책 효과

3 경제충격 효과의 산업간 공행성 분석

4 서비스업 발전을 통한 내외수 균형성장: 기대효과 및 리스크

5 Cross-country-heterogeneous and Time-varying Effects of Unconventional Monetary Policies in AEs on Portfolio Inflows to EMEs

6 인터넷뱅킹, 결제성예금 및 은행 수익성과의 관계 분석

7 Dissecting Foreign Bank Lending Behavior During the 2008-2009 Crisis

8 The Impact of Foreign Banks on Monetary Policy Transmission during the Global Financial Crisis of 2008-2009: Evidence from Korea

9 Welfare Cost of Business Cycles in Economies with Individual Consumption Risk

10 Investor Trading Behavior Around the Time of Geopolitical Risk Events: Evidence from South Korea

11 Imported-Inputs Channel of Exchange Rate Pass-Through: Evidence from Korean Firm-Level Pricing Survey
Seungjin Baek •

Kimmo Soram ki • Jaeho Yoon

정호성·임호성

황선웅·민성환 ·

신동현 · 김기호

김승원 · 황광명

Kyoungsoo Yoon •

Christophe Hurlin

이동규·전봉걸

Moon Jung Choi •

Eva Gutierrez •

Maria Soledad Martinez Peria

Bang Nam Jeon •

Hosung Lim • Ji Wu

Martin Ellison •

Thomas J. Sargent

Young Han Kim • Hosung Jung

Jae Bin Ahn •

Chang-Gui Park 


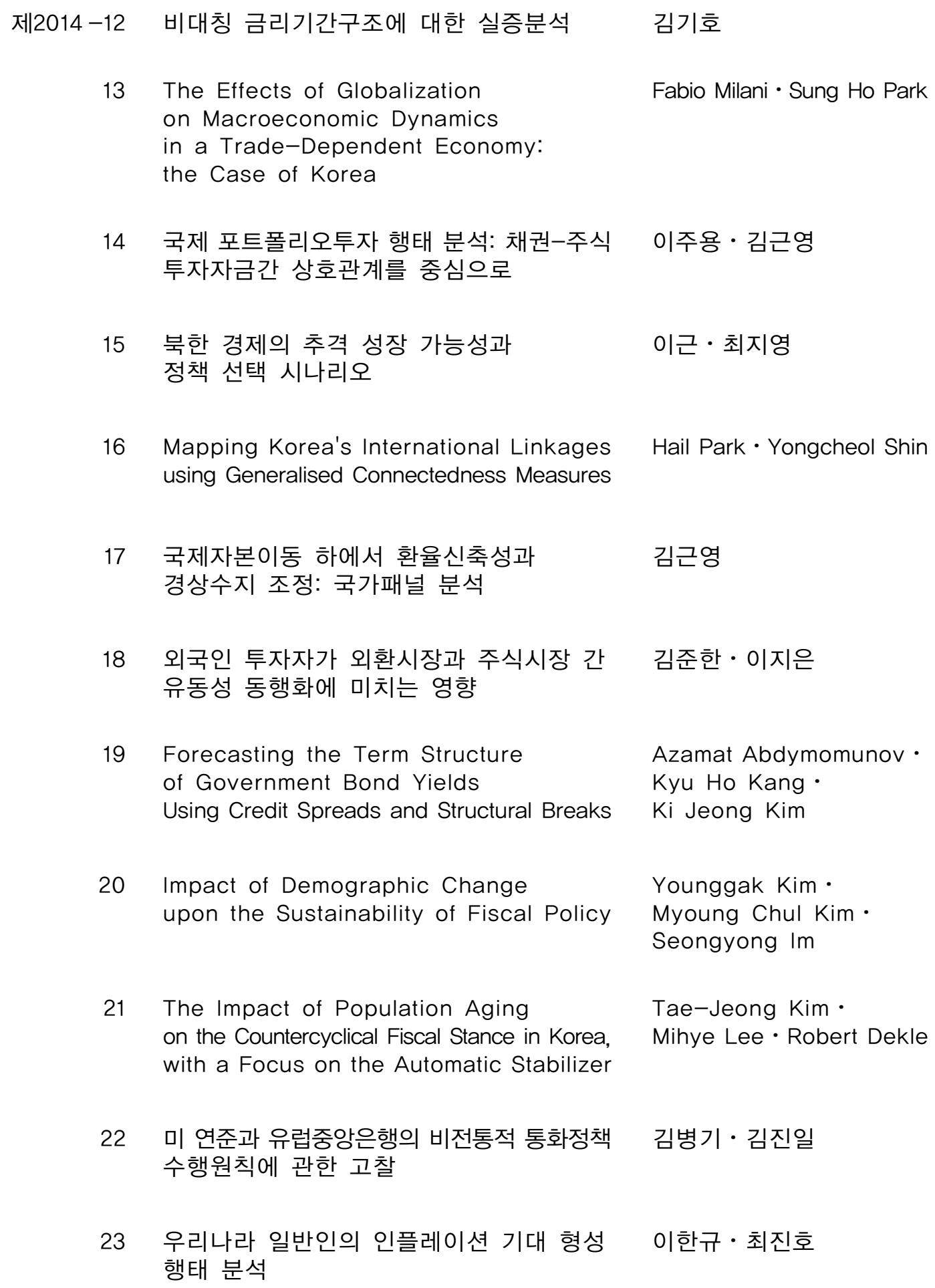

22 미 연준과 유럽중앙은행의 비전통적 통화정책 수행원칙에 관한 고찰

23 우리나라 일반인의 인플레이션 기대 형성 행태 분석

Fabio Milani · Sung Ho Park

이주용·김근영

이근 · 최지영

Hail Park $\cdot$ Yongcheol Shin

김근영

김준한·이지은

Azamat Abdymomunov . Kyu Ho Kang •

$\mathrm{Ki}$ Jeong Kim

Younggak Kim $\cdot$

Myoung Chul Kim.

Seongyong Im

Tae-Jeong Kim •

Mihye Lee $\cdot$ Robert Dekle

김병기·김진일

이한규-최진호 


\section{제2014-24 Nonlinearity in Nexus between Working Hours and Productivity \\ Strategies for Reforming Korea's Labor Market to Foster Growth}

글로벌 금융위기 이후 성장잠재력 확충: 2014 한국은행 국제컨퍼런스 결과보고서

인구구조 변화가 경제성장률에 미치는 영향: 자본이동의 역할에 대한 논의를 중심으로

\section{Safe Assets}

확장된 실업지표를 이용한

우리나라 노동시장에서의 이력현상 분석

Entropy of Global Financial Linkages

International Currencies Past, Present and Future: Two Views from Economic History

금융체제 이행 및 통합 사례:

남북한 금융통합에 대한 시사점

Measuring Price-Level Uncertainty and Instability in the U.S., 1850-2012

고용보호제도가 노동시장 이원화

및 노동생산성에 미치는 영향

해외충격시 외화예금의 역할 : 주요 신흥국 신용스프레드에 미치는 영향을 중심으로

실업률을 고려한 최적 통화정책 분석

우리나라 무역거래의 결제통화 결정요인 분석

Global Liquidity Transmission to

Emerging Market Economies, and Their Policy Responses
Dongyeol Lee $\cdot$

Hyunjoon Lim

Mai Dao - Davide Furceri -

Jisoo Hwang .

Meeyeon Kim •

Tae-Jeong Kim

한국은행 경제연구원

손종칠

Robert J. Barro

김현학·황광명

Daeyup Lee

Barry Eichengreen

김병연

Timothy Cogley •

Thomas J. Sargent

김승원

정호성·우준명

김인수·이명수

황광명 · 김경민 ·

노충식·김미진

Woon Gyu Choi ·

Taesu Kang •

Geun-Young Kim •

Byongju Lee 
제2015-1 글로벌 금융위기 이후 주요국

통화정책 운영체계의 변화

2 미국 장기시장금리 변동이 우리나라 금리기간구조에 미치는 영향 분석 및 정책적 시사점

3 직간접 무역연계성을 통한 해외충격의 우리나라 수출입 파급효과 분석

4 통화정책 효과의 지역적 차이

5 수입중간재의 비용효과를 고려한 환율변동과 수출가격 간의 관계

6 중앙은행의 정책금리 발표가 주식시장 유동성에 미치는 영향

7 은행 건전성지표의 변동요인과 거시건전성 규제의 영향

8 Price Discovery and Foreign Participation in The Republic of Korea's Government Bond Futures and Cash Markets

9 규제가 노동생산성에 미치는 영향: 한국의 산업패널 자료를 이용한 실증분석

10 인구 고령화와 정년연장 연구 (세대 간 중첩모형(OLG)을 이용한 정량 분석)

11 예측조합 및 밀도함수에 의한 소비자물가 상승률 전망

인플레이션 동학과 통화정책

Failure Risk and the Cross-Section of Hedge Fund Returns

Global Liquidity and Commodity Prices

15
Foreign Ownership, Legal System and Stock Market Liquidity
김병기·김인수

강규호·오형석

최문정·김근영

김기호

김경민

이지은

강종구

Jaehun Choi · Hosung Lim •

Rogelio Jr. Mercado •

Cyn-Young Park

이동렬·최종일·이종한

홍재화·강태수

김현학

우준명

Jung-Min Kim

Hyunju Kang •

Bok-Keun $\mathrm{Yu}$.

Jongmin $\mathrm{Yu}$

Jieun Lee $\cdot$ Kee H. Chung 


\begin{tabular}{|c|c|c|}
\hline 제2015 -16 & $\begin{array}{l}\text { 바젤 III 은행 경기대응완충자본 규제의 } \\
\text { 기준지표에 대한 연구 }\end{array}$ & 서현덕·이정연 \\
\hline 17 & 우리나라 대출 수요와 공급의 변동요인 분석 & 강종구·임호성 \\
\hline 18 & 북한 인구구조의 변화 추이와 시사점 & 최지영 \\
\hline 19 & $\begin{array}{l}\text { Entry of Non-financial Firms and Competition } \\
\text { in the Retail Payments Market }\end{array}$ & Jooyong Jun \\
\hline 20 & $\begin{array}{l}\text { Monetary Policy Regime Change } \\
\text { and Regional Inflation Dynamics: } \\
\text { Looking through the Lens of } \\
\text { Sector-Level Data for Korea }\end{array}$ & $\begin{array}{l}\text { Chi-Young Choi } \\
\text { Joo Yong Lee } \\
\text { Roisin O'Sullivan }\end{array}$ \\
\hline 21 & $\begin{array}{l}\text { Costs of Foreign Capital Flows } \\
\text { in Emerging Market Economies: } \\
\text { Unexpected Economic Growth } \\
\text { and Increased Financial Market Volatility }\end{array}$ & $\begin{array}{l}\text { Kyoungsoo Yoon } \\
\text { Jayoung Kim }\end{array}$ \\
\hline 22 & $\begin{array}{l}\text { 글로벌 금리 정상화와 통화정책 과제: } \\
\text { 2015년 한국은행 국제컨퍼런스 결과보고서 }\end{array}$ & 한국은행 경제연구원 \\
\hline 23 & $\begin{array}{l}\text { The Effects of Global Liquidity } \\
\text { on Global Imbalances }\end{array}$ & $\begin{array}{l}\text { Marie-Louise DJIGBENOU-KRE · } \\
\text { Hail Park }\end{array}$ \\
\hline 24 & 실물경기를 고려한 내재 유동성 측정 & 우준명·이지은 \\
\hline 25 & Deflation and Monetary Policy & Barry Eichengreen \\
\hline 26 & $\begin{array}{l}\text { Macroeconomic Shocks } \\
\text { and Dynamics of Labor Markets in Korea }\end{array}$ & $\begin{array}{l}\text { Tae Bong Kim } \\
\text { Hangyu Lee }\end{array}$ \\
\hline 27 & $\begin{array}{l}\text { Reference Rates and Monetary Policy } \\
\text { Effectiveness in Korea }\end{array}$ & $\begin{array}{l}\text { Heung Soon Jung } \\
\text { Dong Jin Lee } \\
\text { Tae Hyo Gwon. } \\
\text { Se Jin Yun }\end{array}$ \\
\hline 28 & Energy Efficiency and Firm Growth & $\begin{array}{l}\text { Bongseok Choi } \\
\text { Wooyoung Park } \\
\text { Bok-Keun Yu }\end{array}$ \\
\hline 29 & $\begin{array}{l}\text { An Analysis of Trade Patterns } \\
\text { in East Asia and the Effects of } \\
\text { the Real Exchange Rate Movements }\end{array}$ & $\begin{array}{l}\text { Moon Jung Choi } \\
\text { Geun-Young Kim. } \\
\text { Joo Yong Lee }\end{array}$ \\
\hline 30 & $\begin{array}{l}\text { Forecasting Financial Stress Indices in } \\
\text { Korea: A Factor Model Approach }\end{array}$ & $\begin{array}{l}\text { Hyeongwoo Kim } \\
\text { Hyun Hak Kim• } \\
\text { Wen Shi }\end{array}$ \\
\hline
\end{tabular}


제2016-1 The Spillover Effects of U.S. Monetary Policy on Emerging Market Economies: Breaks, Asymmetries and Fundamentals

2 Pass-Through of Imported Input Prices to Domestic Producer Prices: Evidence from Sector-Level Data

3 Spillovers from U.S. Unconventional Monetary Policy and Its Normalization to Emerging Markets: A Capital Flow Perspective

4 Stock Returns and Mutual Fund Flows in the Korean Financial Market:

A System Approach

5 정책금리 변동이 성별·세대별 고용률에 미치는 영향

6 From Firm-level Imports to Aggregate Productivity: Evidence from Korean Manufacturing Firms Data

7 자유무역협정(FTA)이 한국 기업의 기업내 무역에 미친 효과

8 The Relation Between Monetary and Macroprudential Policy

9 조세피난처 투자자가 투자 기업 및 주식 시장에 미치는 영향

10 주택실거래 자료를 이용한 주택부문 거시 건전성 정책 효과 분석

11 Does Intra-Regional Trade Matter in Regional Stock Markets?: New Evidence from Asia-Pacific Region

12 Liability, Information, and Anti-fraud Investment in a Layered Retail Payment Structure

Testing the Labor Market Dualism in Korea
Geun-Young Kim •

Hail Park •

Peter Tillmann

JaeBin Ahn •

Chang-Gui Park •

Chanho Park

Sangwon Suh

Byung-Soo Koo

Jaebeom Kim •

Jung-Min Kim

정성엽

JaeBin Ahn •

Moon Jung Choi

전봉걸·김은숙 · 이주용

Jong Ku Kang

정호성·김순호

정호성·이지은

Sei-Wan Kim • Moon Jung Choi

Kyoung-Soo Yoon • Jooyong Jun

Sungyup Chung •

Sunyoung Jung

최지영 비공식부문 분석 


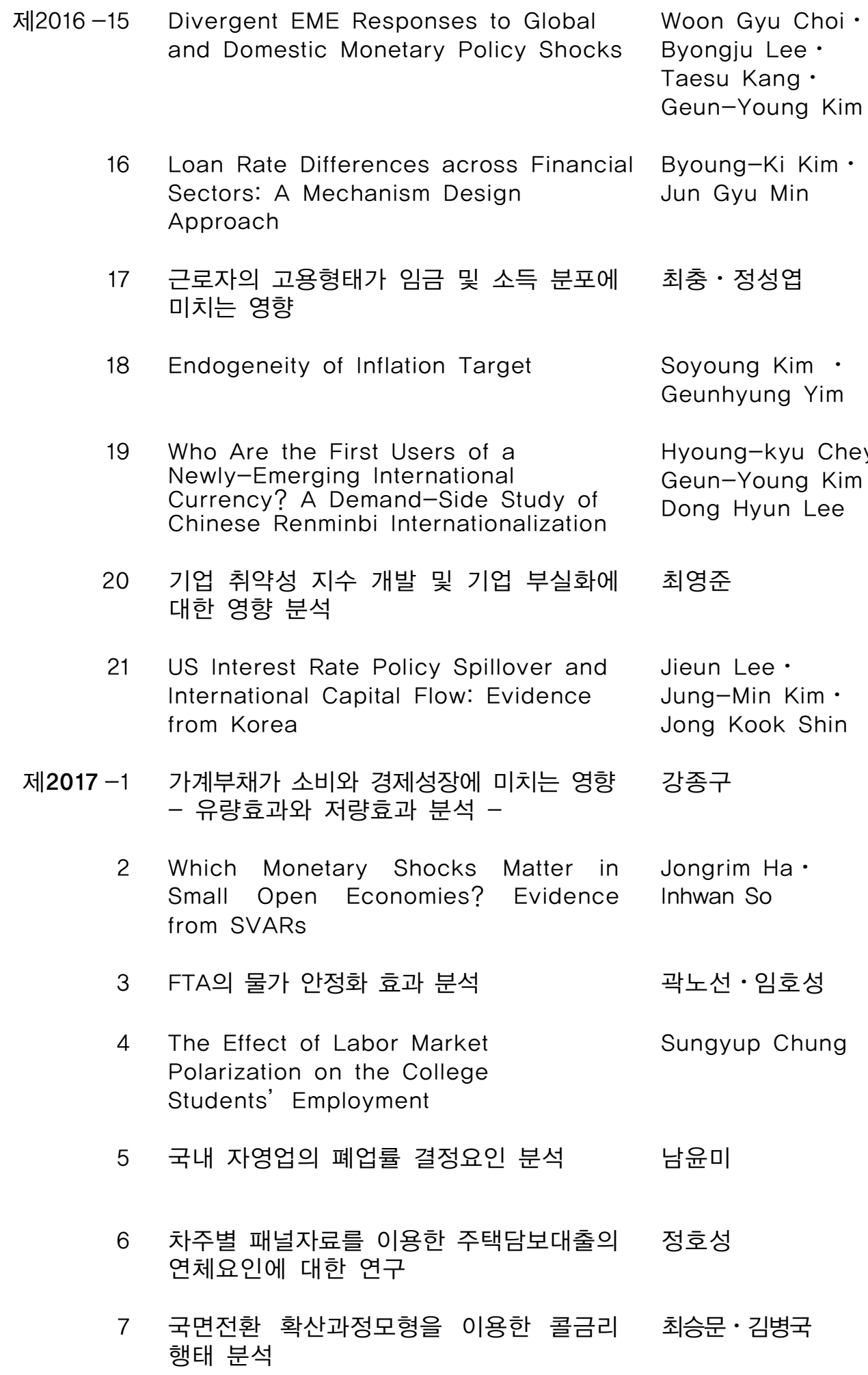

20 기업 취약성 지수 개발 및 기업 부실화에 최영준 대한 영향 분석

21 US Interest Rate Policy Spillover and International Capital Flow: Evidence from Korea

5 국내 자영업의 폐업률 결정요인 분석 남윤미

6 차주별 패널자료를 이용한 주택담보대출의 정호성 연체요인에 대한 연구

7 국면전환 확산과정모형을 이용한 콜금리 최승문-김병국 행태 분석 
제2017-8 Behavioral Aspects of Household

Portfolio Choice: Effects of Loss

In Do Hwang

Aversion on Life Insurance Uptake and Savings 